Andrews University

Digital Commons @ Andrews University

1983

\title{
Classroom Teachers' Perceptions Of Seventh-Day Adventist Academy Principal's Effectiveness In The Lake Union Conference
}

Ritch Enos Kacelenga

Andrews University

Follow this and additional works at: https://digitalcommons.andrews.edu/dissertations

Part of the Educational Administration and Supervision Commons, and the Educational Assessment, Evaluation, and Research Commons

\section{Recommended Citation}

Kacelenga, Ritch Enos, "Classroom Teachers' Perceptions Of Seventh-Day Adventist Academy Principal's Effectiveness In The Lake Union Conference" (1983). Dissertations. 477.

https://digitalcommons.andrews.edu/dissertations/477

https://dx.doi.org/10.32597/dissertations/477

This Dissertation is brought to you for free and open access by the Graduate Research at Digital Commons @ Andrews University. It has been accepted for inclusion in Dissertations by an authorized administrator of Digital Commons@ Andrews University. For more information, please contact repository@andrews.edu. 


\section{INFORMATION TO USERS}

This reproduction was made irom a cupy of a document sent to us for microtilming. Whale the most advanced lechnology has been used to photograph and reproduce this focument. the quality it the reproduction is heavily dependent upon the fuality of the material submitted.

The tiollowing explanation of techniques is provided to help ilanfy markings or totations which may appear on this reproduction.

$\therefore$ The itgn or "target" ior pages apparently lacking from the document pirotographed is "Vissing Pige(s)". It it was possible to obtain the missing pagetsi or section. they are ipliced into the film along with adjacent pages. This nay have necessitated cutting through an image and duplicating adjacent pages to assure complete continuity.

$\therefore$ When an image on the film is obliterated with a round black mark. it is an endication of etther blurted copy because of movement during exposure. juplicate copy. or copynghted materials that should not have been filmed. For blurred pages. a good image of the page can be found in the adjacent frame. i copynghted materals were deleted. a target note will appear listing the pages in the adjacent trame.

$\therefore$ When a map. drawing or thart. atc.. is part of the material being photographed. I detinite method of "iectioning" the material has been tollowed. It is atstomary to begin filming at the upper lett hand comer of a large sheet and to continute trom lett to right in equal sections with imall overlaps. If necessary. ectuoning is contunued dyam heginning helow the tirs: row and continuing on intil complete.

1. For illustrations that annot he satistactonly reproduced by rerographic neans. photographic arints ian he purchased at additional cost and inserted nto your verographic ingy. These pnnts are avaliable upon request from the Dissertations Customer Services Denartment.

-. Some pugess in any document may have indistinct pront. In all iases the best wallable cony has been rilmed.

\section{University Microfilms International}


Reproduced with permission of the copyright owner. Further reproduction prohibited without permission. 
Kacelenga, Ritch Enos

CLASSROOM TEACHERS' PERCEPTIONS OF SEVENTH-DAY ADVENTIST ACADEMY PRINCIPAL'S EFFECTIVENESS IN THE LAKE UNION CONFERENCE

Andrews University

ED.D. 1983

\author{
University \\ Microfilms \\ International 300 N. Zeeb Road. Ann Arbor. M1 48106
}

\title{
Copyright 1982
}

by

Kacelenga, Ritch Enos

All Rights Reserved 
Reproduced with permission of the copyright owner. Further reproduction prohibited without permission. 


\section{PLEASE NOTE:}

In all cases this material has been filmed in the best possible way from the available copy.

Problems encountered with this document have been identified here with a check mark

1. Glossy photographs or pages

2. Colored illustrations, paper or print

3. Photographs with dark background

4. Illustrations are poor copy

5. Pages with black marks, not original copy

6. Print shows through as there is text on both sides of page

7. Indistinct, broken or small print on several pages

8. Print exceeds margin requirements

9. Tightly bound copy with print lost in spine

10. Computer printout pages with indistinct print

11. Page(s)__ lacking when material received. and not available from school or author.

12. Page(s) ___ seem to be missing in numbering only as text follows.

i3. Two pages numbered Text follows.

14. Curling and wrinkled pages

15. Other

\section{University Microfilms International}


Andrews University

School of Graduate Studies

\title{
CLASSROOM TEACHERS' PERCEPTIONS OF SEVENTH-DAY ADVENTIST ACADEMY \\ PRINCIPAL ' $S$ EFFECTIVENESS IN \\ THE LAKE UNION CONFERENCE
}

\author{
A Dissertation \\ Presented in Partial Fulfillment \\ of the Requirements for the Degree \\ Doctor of Education
}

by

Ritch Enos Kacelenga

April 1983 
CLASSROOU. TEACHERS' PERCEPTIOIS OF

¿EVESTH-CAŸ ADVENTIST ACAOEYYY

PRIICEPAL'S EFFECTIVEIICSS IN

THE LAl:E UHIOH CONFEES:ICE

\section{$A$ dissertation \\ presented in oartiai fulfillment \\ of the requirs:ants for tic degree \\ Joctor ar Educacion}

by

Pitch Encs íaceleriga

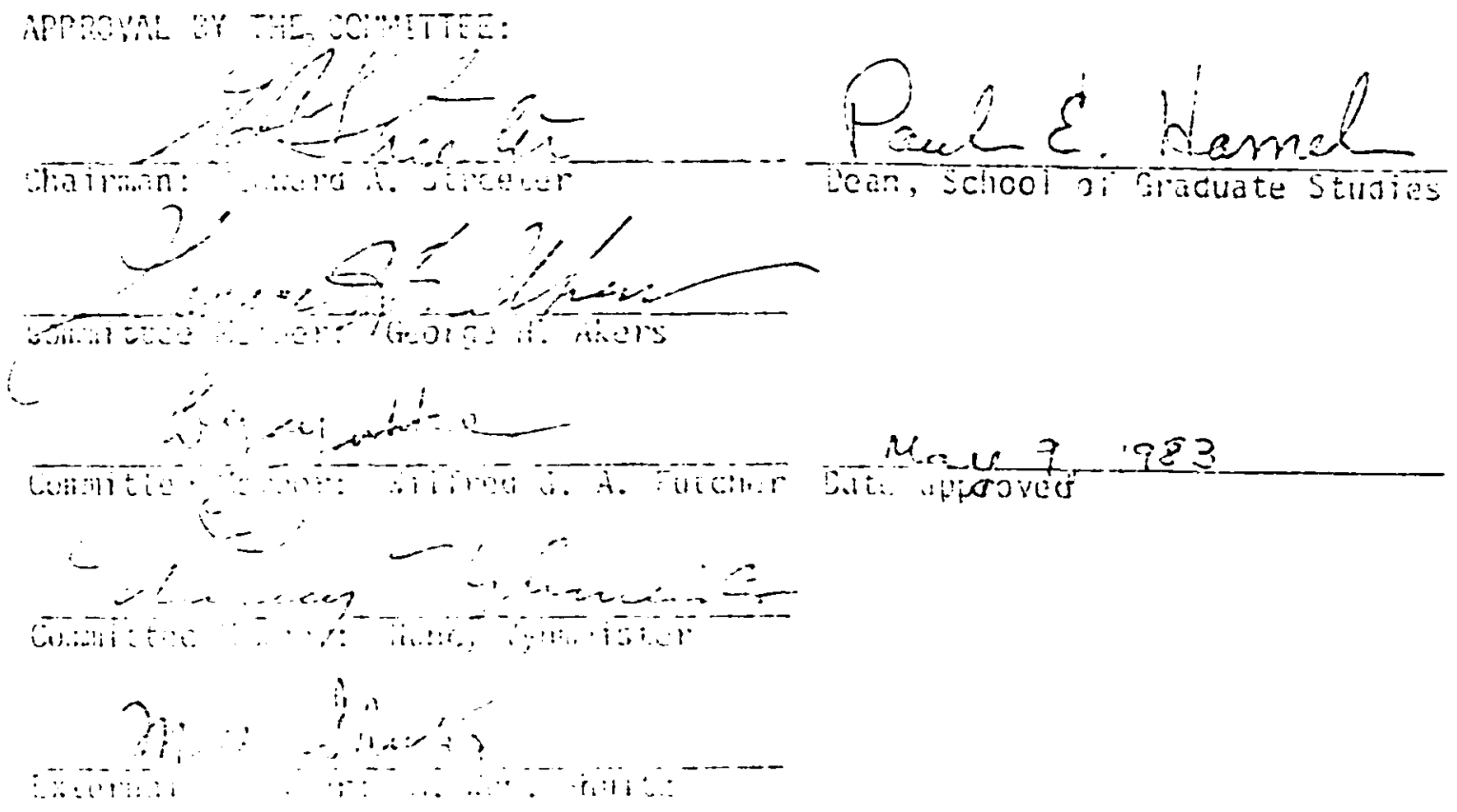




\section{ABSTRACT}

\section{CLASSROOM TEACHERS' PERCEPTIONS OF \\ SEVENTH-DAY ADVENTIST ACADEMY \\ PRINCIPAL'S EFFECTIVENESS IN \\ THE LAKE UNION CONFERENCE}

by

Ritch Enos Kacelenga

Chairman: Edward A. Streeter, Ed.D. 


\section{ABSTRACT OF GRADUATE STUDENT RESEARCH}

Doctoral Dissertation

Andrews University

Department of Education

Title: CLASSROOM TEACHERS' PERCEPTIONS OF SEVENTH-DAY ADVENTIST

ACADEMY PRINSIPAL'S EFFECTIVENESS IN THE LAKE UNION COÄFERENCE.

Vame of researcher: Ritch Enos Kacelenga

Name and title of faculty adviser: Edward A. Streeter, Ed.0.

Date completed: April 1983.

\section{Problem}

In the Seventh-day Adventist educational system, a need exists for research concerning the intercersonal relationshids between scr.opl srincipals and teachers, particularly regarding the way in shich teachers perceive the princioal's role. A school principal is in the unique position of being able, indedendently, to affect the functioning of an entire school staff. The teachers' jerceptions of the orincipal affect their interpersonal relationships and, consequently, the school climate. There is a need to know about this aspect in orcer to work cut effective ore-service and in-service training for school orincidals. 
Method

All teachers in the ten academies of the Lake Union Conference served as the population sample. A questionnaire was used to collect data from the teachers regarding their perceptions of an SDA academy orincidal's effectiveness in five functional areas of administration. The data were first analyzed descriotively. Then four hypotheses were sested for statistical significance by independent t-test and one-way analysis of variance for repeated measures.

Conclusions

1. Teachers differed slightly in their perceptions of the principal's effectiveness in the five functional areas of administration.

2. Overall results showed that teachers strongly agreed that the orincipal was effective in spiritual climate.

3. Teachers also agreed that the principal was effective in management. The school principal needed to improve in the other areas, especially in school-community relations.

1. Teachers with most experience in teaching (ten or more years of teaching) perceived the principal to be most effective in school management and least effective in curriculum and instruction.

\section{Recommendations}

1. Academy orincipals should attempt to discover how the classroom teachers Derceive the princidais' effectiveness and try to enter into some kind of dialogue between themselves and the teachers for mutual development in their relations. 
2. When niring academy principals, preference should be given to candidates who demonstrate abrlity to listen to others and are skillful in human relations as well as in administrative and supervising competencies.

3. Teachers' perceptions of principal's effectiveness can be used as part of a needs assessment in order to plan a practical and effective in-service training for those academy principals already on the job. 
TABLE OF CONTENTS

LIST OF TABLES ......................... v ACKNOWLEDGEMENTS ........................... vii Chapter

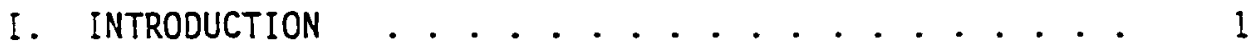

Statement of the Problem . . . . . . . . . 2

Purpose of the Study ............... 3

Questions to be Examined............ 3

Importance of the Study ............. 3

Definition of Terms ............. 4

Hypotheses ................. 6

Delimitations .............. . . . 7

Organization of the Study ........... . . 8

II. REVIEN OF LITERATURE ................. 9

Introduction ................. . . . . 9 9

Teachers' Perceptions of the Principal . . . . . 11

The Principais Need to Know How Group Members 12

Different Constituencies Perceive the Principal

Differently ............... . 16

The Principal as an Instructional Leader . . . . 20

An Idea 1 Principal ............ . . 23

Related Studies . . . . . . . . . . . 26

Summary .................. 30

III. RESEARCH DESIGN ................. 32

Type of Research . . . . . . . . . . . 32

Population................. . . . 32

Sample ................. . . 33

Questionnaire . . . . . . . . . . . . . 33

Collection of Data............ . . . 36

Descriptive Analysis of Data.......... . 37

Statement of Hypotheses and Hethods of Analysis. . 37

Summary ................. . 40

iV. PRESENTATION AND ANALYSIS OF DATA ...... 42 
Collection of Data............. . . 42

Ranking of Academy Principals ......... 43

Demographic Descriptions .. . . . . . . . . . 44

Measurement Data on the Instrument ......... 48

Descriptive Analysis of Basic Data on Part II of

the Questionnaire ........... . 48

Comparison of Perceptions of the Various Teacher

Categories............. 80

Hypothesis Testing............ 82

Summary . . . . . . . . . . . . . . 90

\%. SUMMARY, CONCLUSIONS, AND RECOMMENDATIONS ..... 93

Summary .................. . 9 93

Conclusions . . . . . . . . . . . . . . . 99

Recommendations to the Lake Union Conference. . . 101

Recommendations for Further Research . . . . . . 102

APPENDIX A . . . . . . . . . . . . . 104

APPENDIX B . . . . . . . . . . . . . . 114

APPENDIX $\subset \ldots \ldots \ldots \ldots . \ldots \ldots$

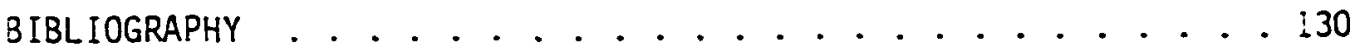

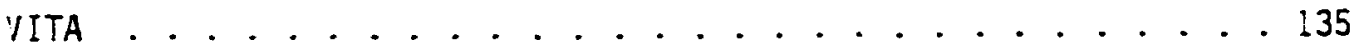


I Ranking of Academy Principals According to Responses of Superintendents of Schools ............. 44

2 Distribution of Sex and Age among Teachers ...... 45

3 Distribution of Highest Earned College Degree among Teachers ................ 46

4 Distribution of College Graduation Dates among Teachers ................ 47

5 Distribution of Teachers According to Teaching Experience (Excluding the 1982-1983 School Year) . . . 48

6 Distribution of Teachers According to Teaching Service in the Present School (Excluding the 1982-1983 School Year) ................ 49

7 Reliability and Item Discrimination.......... E1

8 All Teachers' Perceptions of Academy Principal's Effectiveness by Ranked Item . . . . . . . . . . 52

9 Functional Administrative Areas Ranked According to the Mean Based on All Teachers' Responses........ . 55

10 Male Teachers' Perceptions of Academy Principal's Effectiveness by Ranked Item . . . . . . . . . . 57

11 Functional Administrative Areas Ranked According to the Mean Based on 'Ma le Teachers' Responses ....... 58

12 Female Teachers' Perceptions of Academy Principal's Effectiveness by Ranked Item . . . . . . . . . . 59

13 Functional Administrative Areas Ranked According to the Mean Based on Female Teachers' Responses ...... 50

14 Perceptions of Teachers (with M.A. Degree) of Academy Principal's Effectiveness by Ranked Item ...... 61 
15 Functional Administrative Areas Ranked According to the Mean Based on Responses of Teachers with M.A. Degree . . . . . . . . . . . . . .

16 Perceptions of Teachers (with Other Levels of Education) of Academy Principal's Effectiveness by Ranked Item . 63

17 Functional Administrative Areas Ranked According to the Mean Based on Responses of Teachers with Other Levels of Education..................

18 Perceptions of Teachers (with 1-4 Years Teaching Experience) of Principal's Effectiveness by Ranked Item. .0 .

19 Functional Administrative Areas Ranked According to the Mean Based on Responses of Teachers with 1-4 Years Teaching Experience . . . . . . . . . . . .

20 Perceptions of Teachers (with 5-9 Years Teaching Experience) of Principal's Effectiveness by Ranked Item . . . . . . . . . . . . . . . .

21 Functional Administrative Areas Ranked According to the Yean Based on Responses of Teachers with 5-9 Years ieaching Experience ..............

22 Perceptions of Teachers (with Ten or More Years Teaching Experience) of Principal's Effectiveness by Ranked Item . . . . . . . . . . . . . . . . .

23 Functional Administrative Areas Ranked According to the ilean Based on Responses of Teachers with Ten or More Years Teaching Experience ............ il

24 Perceptions of Teachers (with Less than One Year of Teaching in Present School) of Principal's

Effectiveness by Ranked Iten . . . . . . . . . .

25 Functional Administrative Areas Ranked According to the Mean Based on Responses of Teachers with Less than One Year of Teaching in Present School........ 73

26 Perceptions of Teachers (with 1-4 Years of Teaching in Present School) of Principal's Effectiveness by Ranked Item . . . . . . . . . . . . 74

27 Functional Administrative Areas Ranked According to the Mean Based on Eesponses of Teachers with 1-4 Years of Teaching in P:osent School ............ 
28 Perceptions of Teachers (with 5-8 Years of Teaching in Present Schooll of Princioal's Effectiveness by Ranked Item.................. 76

29 Functional Administrative Areas Ranked According to the Mean Based on Responses of Teachers with 5-8 Years of Teaching in Present School ..........

30 Perceptions of Teachers (with over Eight Years of Teaching in Present Schooll of Princidal's Effectiveness by Ranked Item ................

31 Functional Administrative Areas Ranked According to the Mean Based on Responses of Teachers with over Eight Years of Teacning in Present School.

32 Hypothesis 1. T-Test on All Areas ........ 83

33 Means and Standard Deviations. Five Areas - All Respondents................. 84

34 Analysis of Variance - Hypothesis 2......... 84

35 Table of Contrasts between Means. Hypothesis 2 . . 85

36 Means and Standard Deviations Five Areas - Group 1 Principals................. 86

37 Analysis of Variance - Hypothesis 3........ 87

38 Table of Contrasts between Means. Hypothesis 3... 37

39 Means and Standard Deviations Five Areas - Group 2 Principals...................... 38

40 Analysis of Variance - Hypothes is 4....... 39

41 Table of Contrasts between Means. Hypothesis $4 . . .90$

vii 


\section{ACXNOWLEDGEMENTS}

I am deeply indebted to the following persons whose assistance made it possible for this study to be completed:

The doctoral committee chaiman, Dr. E. A. Streeter, who patiently guided me at every stage of the study, and even went out of his way to speak or phone to respondents who delayed in returning the questionnaire; Dr. G. H. Akers who suggested changes in the format of the questionnaire before it was sent out to the respondents; Dr. Nancy Vyhmeister who critically edited each chapter and made helpful suggestions; and Dr. W. G. A. Futcher who spent many hours of his own free time working with the computer and supervising the statistical aspects of the study.

My gratitude also goes to Elder $W$. E. Minder, Director of Education in the Lake Union Conference, and to his secretary, Agnes Anderson, for kindly and promptly supplying me with information regarding the academies in the Lake Union Conference. In addition, I am grateful to the Educational Management Team of the Lake Union Conference for granting me permission to collect data from the academy teachers. Many thanks to the teachers themselves and to the school superintendents for responding to the questionnaire.

Finaliy, my appreciation goes to my wife Ruth, my daughter Mercy-Pam, and my son Lesile for putting up with all the financial and social inconveniencies in the course of writing this dissertation. 
CHAPTER I

INTRODUCTION

Leadership has been characterized as being at the heart of administration (Gore \& Silander, 1959, p. 97); and Fiedler (1974) said that an organization without effective leadership is in trouble (p. 1). Thomas Gordon (c 1977) warned that

Leaders can make or break a group. Their attitudes and behavior strongly influence the group's performance and also the amount of satisfaction enjoyed by group members, as everyone knows from direct experience with teachers, administrators, supervisors, committee chairpersons, coaches, managers, clergy, and elected officials. (p. 2)

Regarding leadership in a school situation, evidence indicates that the principal's performance has a direct bearing not only on the teachers' performance but also on the functioning of the whole schooi (Abrell \& Hanna, 1978).

In the Seventh-day Adventist educational system, a need exists for research concerning the interpersonal relationships between school principals and teachers, particularly regarding the way in which teachers perceive the principal's role. A school principal is in the unique position of being able, independently, to affect the functioning of an entire school staff (Fox, 1974; Hittmer \& Loesch, :976). There is considerable evidence that the principal makes the difference in the school (Conant, 1960; Silberman, 1974; Wellisch et a I., 1978). 
The reacher's perceptions of the principal affect their interpersonal relationships and, consequently, the school climate. However, knowledge of the behaviors pertaining to effective principals is scarce, especially as perceived by their school faculties. There is a need to know about this aspect in order to work out effective pre-service and in-service training for school principals.

\section{Statement of the Problem}

When the first official Seventh-day Adventist academy was established at Healdsburo, in California, in 1882, there was no need for an administrator. The teaching staff consisted of only two teachers: Sidney Brownsberger and his wife. The total high-school enrollment stood at thirty-three students (Douglass, 1961).

Since the early decades of the twentieth century, an evolutionary change in school administration has taken place. Schools have assumed a definite organizational structure such as elementary grades 1-8, secondary (academy) 3-12, and college. With the increase in enrollment, all types of problems confront the schools. There are demands on the schools to imorove methods and facilities for teaching as well as providing qualified personnel. These expectations have added greater responsibility for facilitative administration by the principal. The complexity of school populations, organizations, and curricula, together with the added responsibility for increased social services, calls for effective principalship. The problem of accountability requires that the school principal be competent. 
Purpose of the Study

In the Seventh-day Adventist formal educational setting, little if any research has been undertaken into the interpersonal relationships between principals and teachers, especially concerning the way in which teachers perceive a principal's role. The teachers' perceptions of the principal affect their relationship and, ultimateIy, the school climate.

The purpose of this study was to identify classroom teachers' perceptions of how effective the Seventh-day Adventist academy Drincipal is in carrying out the functional administrative areas of staff-principal relations, curriculum and instruction, school management, school-community relations, and spiritual climate.

\section{Questions to Be Examined}

There were several questions that needed to be answered:

1. Do teachers distinguish in their perceptions between more capable school principals and those who are less capable?

2. Does length of teaching experience influence a teacher's perception of a principal's effectiveness?

3. Do teachers view differently the effectiveness of the school principal among the five functional areas of administration?

\section{importance of the Study}

Formal education in the United States is facing tremendous jressures from the society which supports it and which it serves. This situation also applies to the Seventh-day Adventist formal educational setting. In the face of rising costs of education in 
the parochial schools, the constituency is wondering whether there is really any difference between the public schools and the non-public schools that would justify the high cost to parents.

Many of the community groups are demanding excellence in education, and school administrators are hard put to achieve this excellence. The school principal, as an administrator, has the difficult task of effecting the necessary changes and adjustments sought by the constituency. In carrying out this task, the principal has to be in a face-to-face relationship with different reference groups such as teachers, supervisors, students, parents, and other members of the constituency.

The review of the literature undertaken at the James White Library for this study does not show any evidence either of the existence of studies concerning teachers' perceptions of Seventh-day Adventist academy principals or of what is considered an effective S.D.A. academy principal. Reading empirical evidence provided by a study of this nature would help the principal become aware of the image that his/her behavior communicates to the staff, the students, the partents, and the community members. He/she would theri try to improve his/her performance as school principal by discarding the undesirable behaviors or practices that militate against being effective. This study has attempted to present such evidence.

\section{Definition of Terms}

The following terms used in this study are intended to convey the meaning as follows: 
Group 1 Principals are those academy principals ranked 1-5. This rating was based on the analysis of the responses of superintendents of schools to the second part of the questionnaire.

Group 2 Principals are those academy principals ranked 6-10. This rating was based on the analysis of the responses of superintendents of schools to the second part of the questionnaire.

Academy is the name applied by Seventh-day Adventists to their secondary schools in the linited States and Canada. These fouryear schools, which are operated as residential and/or nonresidential schools, are also called boarding or non-boarding (day) academies.

Administrator is a full time professional person whose responsibility is to carry out the policies laid down by the board. The administrator also cares for the entire school program. In many schools the administrator is a orincipal-teacher who carries a reduced teaching load in addition to his/her administrative work. Superintendent of Schoois is the director of education for a local conference, and is usually a member of the local academy board of education.

The Functional Administrative Areas are those aspects of administration that are directed daily by the school principal. In this study, these areas are staff-principal relations, curriculum, and instruction, school management, school-community relations, and spiritual climate.

Seventh-day Adventist Church is defined as "A conservative 
Christian body worldwide in extent, evangelical in doctrine, and professing no creed but the Bible. It places strong emphasis on the Second Advent. . . and observes the Sabbath of the Bible, the seventh day of the week (Neufeld, 1976, p. 1325).

General Conference of Seventh-day Adventists refers to the headquarters of the world church organization of Seventh-day Adventists located at Takoma Park, Maryland, near 'rashington, D.C.

Lake Union Conference is an administrative unit of the Seventh-day Adventist Church. It consists of five local conferences encompassing the states of Illinois, Indiana, Michigan, and Wisconsin.

Local Conference is defined as "a unit of S.D.A. Church organization composed of the local churches within a given area such as a state" (Neufeld, 1976, p. 346).

\section{Hypotheses}

The study was designed to test the following experimental hypotheses:

1. There is a significant difference in teachers' perceptions of principal's effectiveness between those principals ranked 1-5 (Group 1) and those ranked 6-10 (Group 2) in all the five functional areas of administration.

2. There is a significant difference in teachers perceptions of principal's effectiveness among the five functional areas of administration for both groups.

3. There is a significant difference in teachers' perceptions of principal's effectiveness among the five functional areas of 
administration for those principals ranked 1-5 (Group 1).

4. There is a significant difference in teacher's perceptions of principal's effectiveness among the five functional areas of administration for those principals ranked 6-10 (Group 2).

\section{Delimitations}

There were several delimitations to this study:

1. The study was restricted to examining SOA academy principals' effectiveness only.

2. Only the perceptions of classroom teachers in those SDA schools were considered.

3. Financial considerations made it necessary to restrict the study to SDA academies in the Lake Union Conference as listed in the Yearbook of the General Conference of Seventh-day Adventists, 1982.

The study included all day and boarding academies, grades 9-12, located within the Lake Union Conference.

4. The sample-selection process did not discriminate by years of teaching experience, level of training (degrees and certification), age, sex, or race of teachers or orincipais.

5. The study did not take into account such school aspects as student enrollment, funding, personnel supervised by the principal, or number and location of school buildings under the charge of the principal, although these were admittedly factors that could influence teachers' perceptions of principal's effectiveness.

6. Variables over which schools had no control, such as race, sex, socio-economic background, were not part of this study. 
Organization of the Study

This study was an inquiry into classroom teachers' perceptions of Seventh-day Adventist academy principal's effectiveness in the Lake Union Conference. The contents of the chapters in this study are outlined as follows:

Chapter I contains an introduction to the study, statement of the problem, purpose of the study, and questions to be examined. It also includes sections on the importance of the study, definitions of terms, hypotheses, delimitations, and an outline of the study.

Chapter II presents a general review of literature on the topic and a review of literature on specific studies relevant to teachers' perceptions of principal's effectiveness.

Chapter III describes the research design and the methods of data analysis.

Chapter IV presents and analyzes the data.

Chapter $V$ is a summary of the study along with conclusions reached from the analysis and evaluations of the data. Implications and recommendations for further study are also included. 


\section{CHAPTER II}

\section{REVIEW OF LITERATURE}

The purpose of this chapter is to investigate from literature how a school principal is perceived by teachers and other reference groups. The chapter consists of the following sections: introJuction, teachers' perceptions of the principal, the principal's need to know how group members perceive him/her, the different perceptions held by different constituencies, the principal as an instructional leader, the ideal principal, related studies, and a summary.

\section{Introduction}

The United States has both public and non-public schools. The public schools are organized into school districts or administrative units. Campbell (1965) stated that, Juring the seventeenth and eighteenth centuries, American schools were essentially private or church institutions. Control rested in the hands of individuals or church groups. It was not until about 1800 that a growing demand for public education was promoted by such men as Thomas Jefferson, Horace Mann, and Henry Barnard. In 1821, the first public secondary school was organized in Boston, Massachusetts (p. 3).

As the population increased, the schools had to expand the ir size and services. A "head teacher" was appointed to handle the increasing number of juties required for a school to operate. The 
orincipalship eventually developed from this position. The title "principal teacher" was first used to indicate the position held by a teacher who had been assigned some extra administrative duties. Later, however, the title was shortened to "principal" (Anderson \& Van Dyke, 1972, pp. 4-5).

It is important to note that the first principals were teachers. Because the position developed from the ranks of the classroon teachers, there existed a close relationship between the administrative and instructional tasks (Anderson \& Van Dyke, 1972, p. 4). Michel (1976, p. 23) observed that, consequently, "the orientation of the school principal was decidedly toward the faculty and the staff of the school. He/she was not considered a full member of the central administration" (p. 23). When the position of superintendent developed later in the nineteenth century, the principal began to serve as the liaison person between the central office and the teachers in his/her school (Anderson \& Van Dyke, 1972, p. 5). He/she was thus the instructional leader.

By the 1950s, however, the principal's performance as the instructional leader began to be criticized. Educational administration in general was thought by many to be too authoritatian and resistant to change and innovation. Principals particularly had been the target of some critics who described them as "the most authoritarian group of people left in the United States." They were charged with having "failed to rise to their mission" and were criticized for having emphasized the managerial aspects of administration to the neglect of instructional leadership. Principals were also accused of 
relying on the authority incumbent in their positions rather than on their own knowledge, training, and abilities to be educational leaders (Grieder, 1969, pp. 1540155).

\section{Teachers' Perceptions of the Principal}

Not much research or meaningful literature exists concerning the interpersonal relationships between principals and teachers in the school setting. Researchers have typically investigated the attitudes toward the administrative structure of which the principal is a part (Wittmer \& Loesch, 1976, p. 99).

Trump (1972, p. 4) and Wittmer and Loesch (1976, p. 98) declared that central among the personal relationshios that exist in any school is that between the principal and the teachers. The principal is in the unique position of being able to independently affect the functioning of the entire teaching staff. He/she is the central figure in creating a positive learning climate. These researchers stated that principals who are facilitative persons respond to the needs of students and teachers alike.

However, it is not so much how the leader behaves that counts as how his/her behavior is perceived by teachers. Both the users of the Leadership Behavior Descriptive Questionnaire (LBOQ) and users of Halpin's Organizational Climate Descriptive Questionnaire (OCDQ) assume that how the leader really behaves is less important than how the teachers perceive that behavior; it is their perception of his/ her behavior-- if anything--that influences their own actions and thus determines what is called leadership. Evidence indicates that, in a 
school situation, the principal's performance has a direct bearing not only on the teachers' performance but also on the functioning of the whole school.

Relevant to supervisor [principal]-teacher relationships is the knowledge that teachers not only anticipate, recognize, and interpret the behaviors of supervisors but also anticipate and interpret the total school environment. It follows that they will behave--play their role--in a manner consistent with their perceptions of the situations in which they find themselves. (Abrell \& Hanna, 1978, p. 441)

Silberman (1974) considered the principal as the most important adult in the school in setting the pace when she said:

A school is as good or as bad, as creative or as sterile, as sensitive or as callous, as trusting or as suspicious, as flexible or as rigid, as free or as inhibited, as encouraging or as threatening, as the person who heads it up. ( $p .50)$

Conant (1960) said that "the difference between a good school

and a poor school is often the difference between a good and a poor principal. A good school invariably means strong leadership by the principal" (p. 37). Gross and Herriott (1965) concluded, on the basis of their findings in the National Principalship Study, that

of all the administrative officials in the complex bureaucracy that manages public school systems... , few have at their command greater potentialities for influencing directly the type and quality of education young pupils are to receive than has the elementary school principal. He is the school executive in closest contact with the central functions of the school: teaching and learning. ( $p .1)$

\section{The Principals Need to Know How Group}

Members Perceive Them

It is the principal's responsibility to identify teacher attitudes and perceptions and attempt to consolidate them with a view to modifying his/her behavior to satisfy the teachers' expectations (moyer, 1955, 0. 4). 
The Greer, Galanter, and Nordlie study (1954) suggested that the ability to perceive accurately the attitudes of another may have the following consequences:

If one can anticipate the needs and behaviors of other people, he can act behaviors of other people, he can act to satisfy them. By satisfying the needs of others, an individual becomes in effect a "problem solver" for the other person. Research indicates that such problem solvers are often chosen as leaders; the more a leader is perceived as a problem solver, the more the followers appear to be motivated to help the leader. (p. 414)

If there is much difference between the teacher and the principal concerning the principal's functions, teachers become more unsatisfied, less effective, and have less confidence in the principal's leadership abilities (Campbell, 1959, p. 3). Leaders must identify and understand teachers' expectations if an effective working relationship is to result. Carruthers (1977) stated the idea succinctly:

Teachers have certain perceptions of the role the principal is exhibiting or is not exhibiting as the instructional leader of his staff. These perceptions may greatly affect the teachinglearning environment which exists.. . Therefore, it seems apparent that any study dealing with the instructional leadership exhibited by the secondary school principal also should iook to the teacher for feedback. (p. 2)

In their "Study of Teacher-Principal Relationships," whose purpose was to report how teachers felt about their respective principals and the perceptions they had of the principal's role, Nittmer and Loesch (1976) found that a facilitative principal encourages teachers to take an active part in setting the learning climate of the school. Principals who exude confidence in their work tend to transmit their attitude to teachers as well as to students. Teachers, like students, discover that the school climate affects their work. When the climate is safe, teachers feel free to experiment 
and to try new ideas that might better facilitate students' personal growth. When teachers are threatened, they tend to regress to traditional methods that help them to survive on the job (pp. 102103).

Principal-teacher relationships often result in misunderstandings. Principals may think they know what their teachers expect of them; but what they think may not necessarily be the case. Sweitzer's study (1965) found that secondary-school principals do not behave as teachers feel they should. The majority of the discrepancies were noted in the areas of curriculum and instruction, funds and facilities, and personnel development, in that order (p. 383).

Several other studies have been conducted which dealt with teachers' opinions/perceptions of the principal. For example, Bush (1955) described the feelings of teachers regarding the principal's role. Teachers felt that the principal should keep them happy. He/ she should show concern for the teachers' welfare and come to the teachers' defence when necessary. Further, the principal should give concrete help in teaching and yet realize that the classroom is the "teacher's castle" (p. 24).

Goldman (1966) reported that teachers felt that effective principals gave them understanding and help in dealing with their problems and also allowed teachers to participate in the decisionmaking process in the school (p. 301).

Teachers want more proof than talk that the principal is concerned about them and the learning that goes on in the school. According to Ban (1970), it is only through an emphasis on the 
intangibles of the principal-teacher relationship, like empathy, candor, and morale, that the learning process will be aided (p. 443). Lee (1974) has pointed out that more and more instructional supervision, in the traditional sense, has become unacceptable to teachers. As teachers became more professional, better trained, and more selfgoverning, instructional supervision and leadership has to change (p. 28).

Another variable that may affect the school climate is the managerial style of the principal. In their research, Lippitt and White (1947) showed that the leadership style exhibited by a principal has an effect not only on the organizational climate of the school but also on the leadership performance. Lippitt and White further found that the most effective style was democratic leadershio. (p. 319$)$

Stoops and Johnson (1967) developed leadership styles into which leadership actions could be classified. They identified four styles. The first was the democratic leadership which involves helping others to help themselves in the attainment of goals which are important to them. The next was autocratic leadership. This leadership style is exemplified by a dictatorial leader who assumes responsibility for all decisions. Another type was the laissez-faire leadership which is actually no leadership at all in that each member of the group is allowed to act autonomously in setting and achieving individual goals. The fourth type, called paternalistic leadership, can be described as a "bargain type of leadership." The leader tries to influence the group members by giving something the ieader has 
for something the leader wants (pp. 34-37).

\section{Different Constituencies Perceive the Principal Differently}

The review of literature shows that perceptions are not always on the same cognitive levels. Research reveals that how a leader sees his/her role may be markedly different from the way group members perceive it. According to a study undertaken by the Commission on Schools of the North Central Association of the United States, the principals perceived themselves as administrators, performing a ieadership function within that context. They ranked as the highest role that of an administrator and next that of instructional leadership. "Principals indicated that leadership characteristics which deal with the manner in which the principal relates to other people are the most necessary in order to function effectively as a principal" (Lozeau, 1977 , p. 336).

The diverse school constituencies, however, revealed varying perceptions of the principal's role. Of all the different reference groups, probably no other is more important to the school principal than that of teachers who work under his/her supervision. The teacher and the principal are in a complementary role relationship within the school. Each one's expectations serve to define the behavior of the other. Cobb's study (1978) investigated how principals, teachers, and prospective teachers perceived the role of the principal in performing duties. He found that the majority of all three groups agreed on supervision of the instructional program and role of curriculum consultant as the most important aspects of the principal's role. The 
three groups also agreed that office manager and community leader were roles of minor importance:

Teachers and prospective teachers want a principal who will guide and assist them in matters of curriculum and in improving their teaching, who will handle interpersonal relationships with skill, and who will see that agreed-upon goals are carried through to completion. (p. 45)

Divergences sometimes occur between teachers' perceptions of a principal's effectiveness and the principal's perceptions of his/ her own performance. The University of Georgia examined the possible divergences between the way the elementary school principal viewed his/her performance in carrying out specified administrative practices and the way he/she was perceived by teachers of the school. The two groups differed significantly on their evaluation of the principal's performance on twenty-two of the forty-six administrative practices that formed the rating of the principal with respect to the actuating function. However, the groups did not differ in the ratings on the functions of planning, organizing, and evaluating. The principal is more concerned with the curriculum, supervision of instruction, teacher morale, relations with the community, Iunch-rooms, class scheduling, and other duties. His/her efficiency in performing these duties is the criterion by which success as an administrator is measured by the superiors, the lay public, and particularly by the teachers within the school. Most elementary-school principals feel that they perform their duties in an efficient manner (Gentry \& Kenney, in Jarvis, 1969 , p. 88). Is there a difference between subordinates' perceptions of the principal's effectiveness and those of the supervisors? Evidence 
suggests that there is. Griffiths and Fredericksen (1962) stated that - . superiors and subordinates hold conflicting expectations of leader behavior. Superiors tended to rate higher those principals who demonstrate the capacity to stick to the job, understand written communication, and have knowledge of teaching methods and techniques. Teachers, however, rate higher those principals who demonstrate ability to get along with teachers, pupils, and parents, and who show good informal oral communication skill. (pp. 348-349)

Similar findings were obtained by the Stanford University School of Education research team. This research team studied teachers in their classrooms and administrators in their schools. The ratings supplied by teachers, principals, and other administrators varied consistently from audience to audience. The teachers wanted a principal who would guide them, or at least reinforce them, in initiating educational innovations in a human, friendly way. The central staff administrators, however, wanted a principal to keep them informed about what was going on: they wanted their directives to be communicated to the teachers and interpreted to the public (Spindler, 1963, p. 239).

Some of the constituencies that interact with principals are parents and students. How do they perceive the principal in carrying out his/her role? Do their perceptions differ from those of the teachers? Buffington and Medsker (1954) studied the behaviors of the elementary-school principals in Oakland, California.

The research showed that teachers and parents observed principals in relatively different situations. Because of these differences in the conditions under which they made their observations, they emphasized different aspects of the principal's job in describing what they considered to be effective and ineffective behavior on his part. (p. ?5)

The following behaviors of an effective principal, listed in 
the order of frequency, were mentioned by the teachers: (1) provides leadership for the teachers, (2) works with and for children, (3) maintains constructive relationships with the community, (4) provides effectively with individual parents. Each one of these behaviors was subdivided into categories. The parents, on the other hand, described the following behaviors as proper for an effective principal: (1) develops effective relationships with parents' groups and the community, (2) works with, and takes care of, children, and (3) knows parents and gives them assistance. Neither the teachers nor the parents reported critical behaviors regarding the principal's responsibilities in supervising and improving curriculum or instruction and in his/her relationships with the superintendent.

The parents emphasized the principal's personal relationships with them, with pupils, and with the community groups--that is, the parents emphasized personal relationships with them, individually and in groups, and with their children. Both teachers and parents indicated a desire for firmness on the part of the principal in dealing with children and with them. Both groups wanted to have a part in planning and executing the school's program (Administrator's Notebook, in Jarvis, 1969, pp. 77-79).

Other dimensions related to teachers' and parents' perceptions of the principal are discussed in a study by Schutz (1961). The author found that

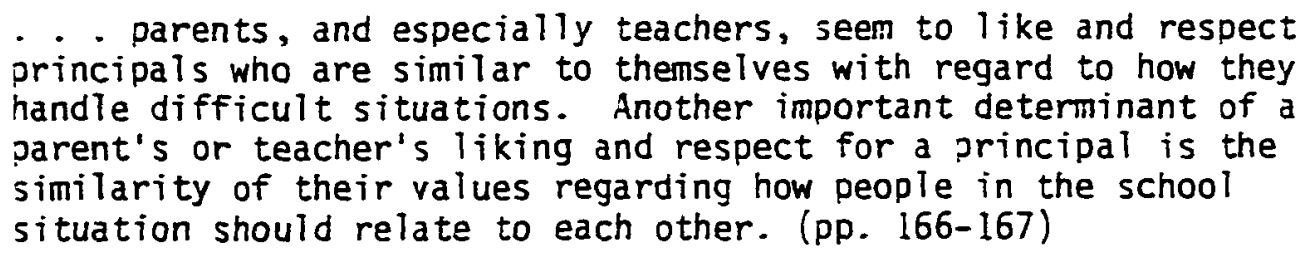


Students' perceptions of the principal's effectiveness enlarge the understanding of the administrative behavior of the school principal, behavior which ultimately reflects itself in more effective educational practices. Felton and Asbury (1978) studied junior highschool students' perceptions of the principal's role and effectiveness. They found "that males have a generally more favorable perception of the principal's effectiveness than do girls" (p. 109). Students did not differ by grade ievel either in their perceptions of the principal's role or in their perceptions of the principal's effectiveness.

\section{The Principal as an Instructional Leader}

The position of the principalship, as mentioned earlier, developed from the ranks of the teachers and has evolved as a position which has as its main function instructional leadership. in a publication of the National Association of Secondary School Principals (NASSP, 1976) entitled Job Descriptions for Principals and Assistant Principals: The Current Trends, a review of job descriptions for principals from across the country was given. Without exception, the principal was still the one person responsible for instructional leadership. in another NASSP publication (Melton, 1970), the improvement of instruction was stated as the principal's main function. This research emphasized the fact that the principal is first and foremost an instructional leader (p. 2).

Few studies, however, have been conducted in the area of instructional leadership. This is particulariy true at the secondary level. in noting this lack of research, Kimbrough (1968) observed that 
There are no definitive studies in support of any one particular view of leadership among all those in the literature. This lack of definitive direction may contribute to much confusion among principals concerning their leadership role in supervision. (p. 142)

However, there are many administrative journals and textbooks which stress that the improvement of instruction should be the area in which the secondary-school administrator devotes most of his/her time. 'Nriters have pointed out that the improvement of the curriculum itself is the primary concern of the principal (Riggs, 1969, p. 45).

This emphasis throughout the literature is exemplified by Brieve (1972) in his statement: "A principal is and must be an instructional leader. He is the single most important individual in influencing the instructional program of his school" (p. 11). Stewert (1967) made a similar observation, pointing out that all other duties of the principal should be "preliminary to, and should contribute to, this primary function of instructional leadership" (p. 20).

The instructional leadership aspect of the principalship was further emphasized by Jones, Salisbury, and Spencer (1969) when they declared that

The prime justification for the position of principal in the school is to give leadership to the teaching-learning process. If the principal spends the major portion of his time at that endeavor, he is placing the emphasis where it belongs. If, however, he spends most of his time counting lunch money, seeing that the playing field is lined, and other similar housekeeping chores, he is not fulfilling the major role his profession and society expect him to play. (p. 209)

However, in spite of this emphasis on the significance of the instructional leadership role for the secondary-school principal, this function is often delegated to others because of time demands and the 
pressures of other administrative duties. In noting this phenomenon, Veagley and Evans (1964) stated:

Writers in the field of administration have been saying for years that the improvement of the instructional program and the curriculum is the most important task of the principal. Several writers have recommended that at least $60 \%$ of the principal's time should be devoted to this important role. (p. 57)

The proliferation of subject area specialists is cited as one possible cause for principals' abandoning their instructional leadership functions. Some principals rely on these specialists to such a degree that their own credibility and expertise in the area of instruction understandably diminisi (Bagby, $1972, \mu .43$ ).

The Emergency School Aid Act (ESAA) In-Depth Study Schools (1978) addressed the question of what characterizes management and organization in schools that are successful in raising student achievement. The major areas of study were, of course, school management and organization. The sample selected consisted of twenty-six schools divided into two groups: one deemed successful and the other unsuccessfut in raising student acadenic achievement. The findirgs revealed that successful schools were more likely to be characterized by administrative leadership in instruction, by coordinated instructional programs, and by an emphasis on academic standards.

Five qualitative school factors concerning school management and organization appeared to differentiate successful from nonsuccessful schools. In successful schools ... the administrators (1) were more concerned with instruction, (2) communicated their views about instruction, (3) took responsibility for decisions related to instruction, (4) coordinated instructional programs, and (5) emphasized academic standards. That leadership qualities were recognized and reported by teachers no doubt reflects the fact that effective administrators also communicated their views concerning instruction to teachers. (Wellisch, ilaclueen, Carriere, \& Dučk, pp. 218-219) 
Not all teachers, however, agree that the principal is an instructional leader. From his findings, Gauerke (1959) concluded that some teachers perceived the principal's responsibilities as routine, clerical, and mechanical duties. Teachers did not consider the principal the "professional head of the school" and further did not feel the principal had responsibilities in the instructional area ( $p$. 112). To his discussion on this subject, McIntyre (1972) added an uncompl imentary observation: "Presumably teachers would be more acceptable of principals' instructional (leadership) roles if the principals were more competent" (pp. 1-2).

\section{An Ideal Principal}

Much research has been conducted in the area of leadership. Shearon (1969) noted that since the turn of the century, over eight hundred research studies dealing with leadership had been undertaken. What are the qualities of an ideal principal, as perceived by the different reference groups? In an anaiysis of more than two hundred studies, Myers (1954) found that

1. No physical characteristics are significantly related to leadership.

2. Although leaders tend to be slightly higher in intelligence than the group of which they are members, there is no significant relationship between superior intelligence and leadership.

3. Knowledge applicable to the problems faced by a group contributes significantly to leadership status.

4. The following characteristics correlate significantly with leadership: insight, initiative, cooperation, originality, judgment, popularity, and communication ski11. (pp. 105-106)

Myers added, however, that the personal characteristics of 
leaders differed according to the situation. It could not be said

that all leaders had any single common characteristic (p. 107).

Further findings of Myers (1954, p. 110), supported by Kimbrough (1968), indicate that

1. Leadership emerges from the interaction of those within a group.

2. The leader is at the focal point of the group's interaction.

3. Leadership acts may be democratic or authoritarian, but never laissez-faire.

4. Leadership is associated with control.

5. The way a leader perceives his/her role determines his/ ner actions.

6. Leadership acts must be perceived by group members as valuable in reaching individual and group goais.

7. Leadership is related to group norms.

8. Perception is an important factor in the emergence of leadership especially in the differentiation of roles of leadership in a system. Objectively measured personality qualities are not as important in leadership as the way in which the led perceive the leader's qualities. (p. 59)

From these findings, it is pertinent to note that the leadership actions both influence and are influenced by the group being led.

What then are the qualities of an ideal leader/principal as perceived by the different reference groups? Several studies provide evidence regarding the qualities considered proper to an ideal principal. The University of Kentucky Interdisciplinary Research Committee (1955) investigated four areas which seemed to be important in the success of administrators: intelligence, techniques, personality, and community. The study found that the successful educational administrator is able to maintain satisfactory relationshios with others 
because of the attitudes held toward him/herself and others. Hie/she makes few value judgments, thinks in cooperative terms, makes few comparisons, and gives sufficienc thought to the things he/she does. The ideal administrator's chief talents are in working with people, eliciting the best from a group, coordinating efforts, and delegating authority. It is important that the administrator have an understanding of the units and the ability to communicate needs from one unit to another (Hopper \& 3ills, 1955, pp. 93-94).

Sharpe (1956) findings confirmed and amplified several of the University of Kentucky Interdisciplinary Research Comittee's findings by studying the opinions and perceptions of a 11 teachers and administrators in a metropolitan school district. He combined their responses to determine the configuration characterizing the ideal principal. He found that

1. The ideal principal was conceived by the various groups of respondents as highly communicative, closely identified with the group led, moderately open in his attitude toward change, and non-dominant.

2. Members of different status groups in the school organization held essentially the same concept of an ideal principal. (p. 57)

Spindler (1963) used the Sharpe study to identify the following characteristics of the ideal principal:

1. Possesses prestige and strong influence in the community.

2. Demonstrates competence in the folloiwng administrative skills:
a. Human relations
b. Teaching and educational techniques
c. Community and public relations
d. Administrative techniques 
3. Acts in discharging his duty in such a way that a high degree of communication between his teacher and himself is realized.

4. Is regarded as an intimate member of the school group but is expected to maintain some social distance between himself and his teachers.

5. Has an open attitude toward change but is not overly active in promoting it.

6. Creates a permissive, democratic atmosphere in his school yet exhibits sufficient domination to make clear to his teachers that he is the leader who is in charge of their activities. (pp. 255-256)

The ideal principal, therefore, is perceived as skillful in communication, decision making, human relations, public relations, and administrative and supervising competencies.

\section{Related Studies}

Christiansen (1957) conducted a study whose purpose was to determine the influence of the behavior of the elementary-school principal upon the school he/she administers. Christiansen studied the behaviors of the principal in relation to the faculty, fellor! principals, supervisors, students, and community members.

He concluded that the behaviors of the elementary-school principal were influential in determining the behavior of the school. in the cases studied, the principal's strengths became the school's strengths, and the principal's weakness the school's weakness.

In the high schools of the Catholic Diocese of Cleveland, Eppley (1967) examined interrelationships among four primary variables:

(1) the teacher's perceptions of the principal's self-regard as an administrator, (2) the teacher's self-rating of confidence in the 
principal's leadership, (3) the teacher's self-rating of satisfaction in the teaching situation, and (4) the teacher's self-rating of effectiveness as a classroom teacher.

Eppley's study is one of the few known researches to use parochial schools as the focus of investigation. The findings were:

1. There was a positive and significant correlation among the primary variabies.

2. Confidence and satisfaction were important intervening variables between the teacher's perception of the principal's selfimage of effectiveness and the teacher's self-rating of effectiveness.

Prascher (1975) undertook a study whose concern was to investigate the effective and ineffective administrative behavior exhibited by high-school principals as judged by a selected group of Colorado classroom teachers.

The analysis of the teachers' responses revealed the following patterns of effective administrative behaviors:

1. The principal listens to others, is receptive to change, is calm in crises, respects others' point of view, is courageous, and shows empathy.

2. The principal leads by acting quickly and decisively to make sure that proper student discipline is maintained so that the teaching-iearning process is allowed to function.

3. The principal supports teachers in conflicts with students, parents, superintendent, and the board of education.

The following patterns of ineffective administrative behavior 
were identified:

1. The principal is reluctant to make decisions and to supervise their implementations, and decisions are not consistent.

2. The principal does not use proper techniques when evaluating teachers, basing evaluations on a few short visits, not stressing teaching techniques, and not suggesting actions a teacher can take to improve.

3. The principal does not provide necessary leadership to make sure that student discipline is maintained in the school.

The objective of Mead's study (1976) was to identify the perceptions and expectations relative to Initiating Structure by which principals establish lines of communication and methods of procedure and consideration by which they establish trust and friendship with their faculties.

In presenting his findings, Mead stated that

1. Desirable leadership behavior for principals was characterized by high performance on the Initiating Structure and Consideration dimensions measured by the Leadership Behavior Description Questionnaire (LBDQ).

2. Teachers and principals indicated that they expected principals to make teachers aware of their expectations, to try out their ideas among their faculties, to clarify their own role, and to be friendly and approachable.

3. Principals were expected to put suggestions made by faculties into operations, give advance notice of changes, be willing to make changes, and act in consultation with their faculties. 
Acosta-Ramos (1978) sought to identify the elementary-school teacher's perceptions of the principal's effectiveness, in Puerto Rico, in discharging the functional administrative areas of staff-principal relations, curriculum and instruction, school management, and schoolcommunity relations.

The overall results of the study showed that principals have to improve in the school-community area. The study also suggested that teachers' perceptions of an effective principal were based mainly on affective aspects of personal relationships in contrast to those of the principals' immediate supervisors, whose perceptions were based on administrative aspects.

In her study, Wallace (1981) sought, through instrumental validation, to investigate perceived satisfaction of teachers with their principals in regard to selected leadership qualities relating to problem interaction between teacher and principal as measured by the Diagnostic Survey for Leadership Improvement and the Leadership Problem Interaction Survey.

The viewpoint of Wallace was that teachers' perceived satisfaction with problem interaction processes as measured by the Leadership Problem Interaction Survey was an indication of the teachers' satisfaction with their principals' leadership performance. The conceptual iramework was developed from basic theories dealing with the evolution and development of human organizations in the area of (1) organizational theory, (2) leadership theory, (3) brain-communications theory, and (4) problem-interaction theory.

Sumarizing the findings of the study, Nallace said that 
effective leadership was necessary to the health of any human organization; and, in a school organization, it was the responsibility of the school leader to understand causal, intervening, and end-result variables within organizational processes and to ensure that leadership performance serves to improve the total effectiveness of the organization.

Summary

This review of literature shows that the principalship developed in response to school expansion and the increasing number of duties required for a school to operate. Because the principalship evolved from the ranks of classroom teachers, there existed a close relationship between administrative and instructional tasks. Thus central among the personal relationships that exist in any school is that between the principal and the faculty. The princioal is the central figure in creating a positive learning climate.

In the Seventh-day Adventist formal educational setting, there is a dearth of literature on the interpersonal relationships between academy principals and teachers. This is especially so with regard to the way in which teachers perceive a principal's role. The academy principal's role is more comprehensive than that of the pubtic school principal. In addition to the usual duties a public school principal performs in the functional-administrative areas of staff-principal relations, curricuium and instruction, school management, and schoclcommunity relations, an academy principal also serves as business manager of the school. In the case of a male academy principal, he 
is frequently an ordained minister of the gospel in view of his leadership role in the spiritual sphere of the school.

Research findings stress that it is not so much how the principal behaves that counts as how his/her behavior is perceived by the various reference groups such as superintendents, parents, students, and community members. In particular, teachers feel that the principal should give them understanding and help in dealing with their problems. The principal should allow teachers to participate in the decision-making process in the school.

There is a difference between subordinates' perceptions of the principal's effectiveness and those of the supervisors. While teachers rate higher those principals who demonstrate ability to get along with teachers, pupils, and parents, superiors tend to rate higher those principals who stick to the job, understand written communication, and have knowledge of teaching methods and techniques. Parents emphasize the principal's personal relationships with them, with students, and with the community groups. It is, therefore, the principal's responsibility to identify the attitudes and perceptions of the various reference groups and attempt to consolidate them with a view to modifying his/her behavior to satisfy the expectations of the constituencies.

The next chapter presents the research design for the study. 


\section{CHAPTER III}

\section{RESEARCH DESIGN}

\section{Type of Research}

The purpose of this study was to identify classroom teachers' perceptions of the effectiveness of the principals of Seventh-day Adventist academy in the Lake Union Conference in carrying out the functional administrative areas of staff-principal relations, curriculum and instruction, school management, school-cormunity relations, and soiritual climate.

This chapter presents a description of the population, sample, questionnaire, descriptive analys is of data, and a statement of the null hypotheses with methods of analysis.

\section{Population}

The study was conducted within the five local conferences of the Lake Union Conference. These local conferences are I1linois, Indiana, Lake Region, Michigan, and 'Nisconsin.

There are ten senior academies in the Lake Union Conference: Broadview Academy in 111 inois, Indiana Academy in Indiana, PetersonWarren and Shiloh Academies in the Lake Region; Adelphian, Andrews, Battle Creek, Cedar Lake, and Grand Ledge Academies in Michigan; and Hisconsin Academy in Wisconsin.

in each local conference there is a superintendent who is 
the imediate supervisor of principals in that conference (Education Directory, 1982-1983, Lake Union Conference). At the beginning of the 1982-1983 school year, there were 137 academy teachers.

Sample

Since there were 137 academy teachers in the whole of the Lake Union Conference all were requested to participate in the study by responding to a questionnaire which was sent to each one of them. Of this number 115 teachers returned the questionnaire in usable form.

\section{Questionnaire}

A two-part questionnaire was used to gather data for the study. The questionnaire was originally designed by José A. AcostaRamos in 1978 at Lehigh University to collect data for his study of teachers' perceptions of principal's effectiveness in Puerto Rico. The first part of this instrument asked for demographic and professional data from the teachers only, without identifying them by name.

The second part of the questionnaire, to which both teachers and superintendents of schools were requested to respond, consisted of forty-eight items relating to the effectiveness of the principal. of these, twelve elicited information on each of four functional administrative areas, namely, staff-orincipal relations, curriculum and instruction, school management-community relations. Acosta-Ramos asked a group of teachers, principals, and supervisors to help in 
developing the statements in terms of completeness of content, significance, readability, and clarity.

A sampie of 110 elementary-school teachers completed the preliminary questionnaire. Of the 110 copies completed, 108 were received in usable form. A total score was calculated for each respondent in each of the four areas. The respondents' scores for each area were ranked from highest to lowest. The respondents in the upper quartile for each area were idenfitied. The same procedure was followed for those in the lower quartile. The differences in means between the statements in the uppor quartile and the lower quartile for each were found. The statements were then ranked from highest to lowest, with respect to their ability to discriminate. The first twelve statements per area in the ranking order were selected for the final questionnaire. Altogether a total of forty-eight statements formed the data-gathering instrument for the study. An item score to total score correlation analysis showed the lowest correlation coefficient of 0.68 and the highest of 0.92 . Reliability coefficient alpha was 0.98992 (see Appendix B).

Acosta-Ramos's questionnaire was modified to suit the purpose of this study. In addition to the four functional administrative areas that Acosta-Ramos identified, a fifth area, called spiritual climate, was included so that teachers could express their perceptions of a principal's effectiveness with regard to the soiritual dimensions of his/her leadership in a Seventh-day Adventist academy. The researcher developed a preliminary list of twenty-nine statements on spiritual climate. Most of these were adapted from 
Evaluative Criteria for SDA Secondary Schools (1982), a self-study instrument used in SDA academies for evaluation purposes by supervisors and accreditation teams throughout the United States and Canada. To ascertain content validity, 3 group of graduate students and professors at Andrews University, who formerly served as SDA academy principals in the United States, responded to the statements. The majority of these former administrators concurred that most of the statements were highly valio.

In addition, a sample of Andrews University graduate-school students who had formerly taught in SOA academies outside of the Lake Union Conference also responded to the preliminary statements. Furthermore, only those whose teaching experience was as fresh as one or two years prior to responding to the statements were asked to Darticipate in this phase of the study. These former teachers were requested to express their perceptions of the principal's effectiveness with regard to the spiritual dimension of the principal's leadership at the school where they had taught. Each respondent drew a circle around one of five numbers following each statement to show the degree of his/her agreement. The numbers represented the following ratings: 5 - strongly agree; 4 - agree; 3 - uncertain; 2 -disagree; 1 - strongiy disagree.

Following an item analysis, the point multiserial correlation coefficient of each item was noted. This coefficient indicated the degree to which the individual item measured consistently with the rest of the instrument, and thus had power to discriminate among stronger and weaker principals. Those twelve items which had good 
point multiserials ( 0.3 or better), and were approved by the judges for content validity, were selected. A total of sixty statements formed the data-gathering instrument for the study (see Appendix A) with twelve statements for each of the five areas of administration. The superintendents of schools were also requested to respond to these sixty statements. The complete questionnaire appears in Appendix $B$.

\section{Collection of Data}

The researcher sought permission from the director of Education for the Lake Union Conference, the superintendents of schools, and the academy principals to collect data from the academies in the Lake Union Conference.

In his reply to the request, the Director wrote a letter on October 19, 1982, stating that he was happy

. . . to inform you that the questionnaire which you presented for review by the Educational Management Team met with the approval of the educators, and you are now free to move ahead with your work.

After attending a meeting of the Educational Management Team at the Lake Union Conference Headquarters in Berrien Springs on November 10, 1982, the principals of the academies agreed to take the questionnaire to the teachers at their respective schools. Each teacher received the questionnaire in a personaliy addressed sealed envelope. With the questionnaire were enclosed two cover letters: one from the Director of Education himself and the other from the researcher.

The letters explained the purpose of the study, asked for the respondent's help in completing the study, reaffirmed the 
confidential treatment that each teacher's answer would receive, and thanked the respondent for his/her cooperation. The sealed envelope also enclosed a stamped, self-addressed envelope for the teacher's use to return the questionnaire.

The respondents who did not return the questionnaire within three weeks were sent a second letter reminding them to complete the questionnaire and return it by December 8,1982 . Other teachers were contacted by phone.

of the 137 copies of the questionnaire that were sent out, $115(84 \%)$ were returned in usable form by February $5,1983$.

Only the second part of the questionnaire was sent to the superintendents to resport too the sixty statements on each of the ten academy principals. All the copies of the questionnaire were received From the superintendents in usable form by February 15, 1983.

Each superintendent's total score of responses to each orincipal was calculated. Then, using the total scores, each principal was ranked from 1-10. Of the ten princidals, the five who were in the upper half of the rank order 1-5 formed Group 1. The other five in the rank order 6-10 were placed in Group 2.

\section{Descriptive Analysis of Data}

The data were analyzed in several ways. The first of these was a descriptive analysis of the data according to five of the demographic data categories of the respondents (teachers only). These categories were (1) male teachers, (2) female teachers, (3) highest college degree earned, (4) teaching experience, and (5) teaching 
experience in the present school. Two demographic data categories were not used for the descriptive analysis of the data. The two categories were boarding school or day school, and age.

Teachers' perceptions were examined by ranking the statements in the second part of the questionnaire according to their weighted scores in the different categories. On the basis of the ranked statements, the five functional areas of administration were also ranked to discover how effectively the academy principal performed in the school.

The other methods of analysis are explained in the next section of this chapter.

\section{Statement of Hypotheses and}

Methods of Analys is

The study sought data to test the following hypotheses, expressed here in the null form as required for statistical significance resting.

Hypothesis 1. There is no significant difference in teachers' perceptions of principal's effectiveness between those principals ranked 1-5 (Group 1) and those ranked 6-10 (Group 2).

This hypothesis was tested separately for each of the five functional areas of administration. Hence there are five sub-hypotheses:

Sub-hypothesis la. There is no significant difference in teachers' perceptions of principal's effectiveness between those principals ranked 1-5 (Group 1) and those principals ranked 6-10 
(Eroup 2) in the functional-administrative area of faculty-principal relations.

Sub-hypothes is $1 b$. There is no significant difference in teachers' perceptions of principal's effectiveness between those principals ranked 1-5 (Group 1) and those principals ranked 6-10 (Group 2) in the functional-administrative area of curriculum and instruction.

Sub-hypothesis 1c. There is no significant difference in teachers' perceptions of principal's effectiveness between those principals ranked $1-5$ (Group 1) and those principals ranked 6-10 in the functional-administrative area of school management.

Sub-hypothesis 1d. There is no significant difference in teachers' perceptions of principal's effectiveness between those principals ranked 1-5 (Group 1) and those principals ranked 6-10 (Group 2) in the functional-administrative area of school community relations.

Sub-hypothesis le. There is no significant difference in teachers' perceptions of principal's effectiveness between those principais ranked 1-5 (Group I) and those principals ranked 6-10 (Group 2) in the functional-administrative area of spiritual climate. Each of these sub-hypotheses was tested by the t-test for independent means.

Hypothesis 2. There is no significant difference in teachers' perceptions of principal's effectiveness among the five functional areas for both groups. 
This hypothes is was tested by one-way analys is of variance for repeated measures.

Hypothes is 3. There is no significant difference in teachers' perceptions of principal's effectiveness among the five functional areas for those principals ranked 1-5 (Group 1).

This hypothesis was tested by one-way analysis of variance for repeated measures.

Hypothes is 4. There is no significant difference in teachers' perceptions of principal's effectiveness among the five functional areas for those principals ranked 6-10 (Group 2).

This hypothesis was tested by one-way analysis of variance for repeated measui'ss. For the test of each hypothes is a was set at 0.05 .

\section{Summary}

ihis chapter has presented a description of the sopulation, sample, questionnaire, descriptive analysis of data, and a statement of the null hypotheses with methods of analysis.

The study was conducted within the five local conferences of the Lake Union Conference where all the ten senior academies formed the population of the study. All the 137 teachers in the ten academies were requested to participate in the study by responding to a questionnaire.

The questionnaire was originally developed by josé A. AcostaRamos in 1978 at Lehigh University to gather data for his study of teachers' perceptions of principal's effectiveness in Puerto Rico in 
four functional administrative areas of staff-principal relations, curriculum and instruction, school management, and school-community relations. The researcher adapted this questionnaire to suit the purpose of this study and added a fifth functional area called spiritual climate.

Following the granting of permission by the Director of Education for the Lake Union Conference, the researcher sent a copy of the questionnaire and cover letters in a sealed envelope to each teacher and each superintendent of schools.

The data were first analyzed descriptively. Then four hypotheses were tested to compare responses of the various groups of respondents. 
CHAPTER IV

PRESENTATION AND ANALYSIS OF DATA

\begin{abstract}
Introduction
The purpose of this study was to identify classroom teacher's perceptions of the effectiveness of the principals of Seventh-day Adventist academies in the Lake Union Conference in carrying out five functionai areas of administration. These five areas are staffprincipal relations, curriculum and instruction, school management, school-community relations, and spiritual climate.

This chapter presents the analysis of data which were collected by a two-part questionnaire. The chapter consists of the following sections: collection of data, ranking of acadeny principals, demographic descriptions, measurement data on the instrument, descriptive analysis of basic data on the second part of the questionnaire according to teacher categories, comparison of perceptions of the various teacher categories, teachers' perceptions of principal's effectiveness: testing the hypotheses, and a summary.
\end{abstract}

\title{
Collection of Data
}

The first part of the questionnaire collected personal and professional data from the teachers. They were requested to state whether they were me or female, their age, the highest college degree they earned, year last degree was granted, teaching experience, 
and length of teaching service in the present school. Of the 137 teachers to whom the questionnaire was sent, 115 responded.

The second part of the questionnaire, consisting of 60 statements, was sent to both classroom teachers and superintendents of schools. There were five superintendents in the Lake Union Conference in the 1982-1983 school year. Of the 60 items relating to the effectiveness of the principal, 12 elicited information on each of the five functional-administrative areas. To show their degree of agreement with the statements each respondent drew a circle around one of five numbers following each statement. The numbers stood for the following ratings: 5 - strongly agree; 4 - agree; 3 - uncertain; 2 disagree; 1 - strongly disagree.

\section{Ranking of Academy Principals}

Table 1 shows how the ten academy principals were ranked in descending order by using total scores derived from the responses of the superintendents of schools. There was a difference of 62 points between the highest score and the lowest score. Of the top five scores, the first score was 15 points higher than the fifth score. There was a gap of 13 points between the fifth and sixth scores. The highest possible score on the questionnaire $(60$ items $\times 5)$ was 300 points.

On the basis of this rank order, the academy principals were divided into two groups: those ranked 1-5 formed Group 1, and those ranked 6-10 formed Group 2. 
TABLE 1

RANKING OF ACADEMY PRINCIPALS ACCORDING TO RESPONSES OF SUPERINTENDENTS OF SCHOOLS

\begin{tabular}{|c|c|c|}
\hline Total Score & Rank & \\
\hline 285 & $1)$ & \\
\hline 276 & 2 & \\
\hline 275 & 3 & Higher $=$ Group 1 \\
\hline 271 & 4 & \\
\hline 270 & 5) & \\
\hline 257 & 6) & \\
\hline 257 & 6 & \\
\hline 242 & 8 & Lower $=$ Group ? \\
\hline 241 & 9 & \\
\hline 223 & 10 & \\
\hline
\end{tabular}

Demographic Descriotion

There are ter academies in the Lake Union Conference, five boarding and five day. Alt these schoois are under the jurisdiction of local conference educational supervision.

iwo of the demographic data categories specified in the first part of the questionnaire asked the teachers to state whether they were male or female and how old they were. Table 2 presents the data on these two categories. The number of teachers who responded consisted of 71 males and 44 females, giving a total of 115, which is an 84 percent response. Two male and one female teachers, however, did not indicate their age category. In the table, therefore, every 
Dercentage stated is of the total of 112 respondents. Twenty-five percent of the 112 responcients fell in the 25-29 age range. Of these, 14.3 percent were women. Of the male teachers, 18 ( 16.0 percent of the respondents) were in the 30-34 age group while 15 (13.4 percent of the respondents) appeared in the 35-39 age group. Thus nearly 44 percent of the 112 respondents were men below forty years of age. Almost 21 percent of the respondents were women below thirty-five years of age.

TABLE 2

DISTRIBUTION OF SEX AND AGE AMONG TEACHERS

\begin{tabular}{|c|c|c|c|c|c|c|}
\hline \multirow{2}{*}{ Age } & \multicolumn{2}{|c|}{ Male } & \multicolumn{2}{|c|}{ Fema le } & \multicolumn{2}{|c|}{ Combined } \\
\hline & N & ${ }^{2}: 1$ & $N$ & :ै & $N$ & $\ddot{0}$ \\
\hline $18-24$ & 4 & 3.6 & 3 & 2.6 & 7 & 5.2 \\
\hline $25-29$ & 12 & 10.7 & 16 & 14.3 & 28 & 25.0 \\
\hline $30-34$ & 18 & 16.0 & 4 & 3.6 & 22 & 19.6 \\
\hline $35-39$ & 15 & 13.4 & 5 & 5.4 & 21 & 18.8 \\
\hline $40-44$ & 6 & 5.35 & 5 & 5.35 & 12 & $\ln .7$ \\
\hline $45-49$ & 4 & 3.6 & 2 & 1.8 & 5 & 5.4 \\
\hline $50-54$ & 5 & 4.4 & 2 & 1.8 & 7 & 6.2 \\
\hline $55-59$ & 3 & 2.7 & 2 & 1.8 & 5 & 4.5 \\
\hline $60-64$ & 1 & 0.9 & 1 & 0.9 & 2 & 1.8 \\
\hline 55 or more & $!$ & 0.9 & 1 & 0.9 & 2 & 1.8 \\
\hline Total & 69 & 61.6 & 43 & 38.4 & 112 & 100.0 \\
\hline
\end{tabular}

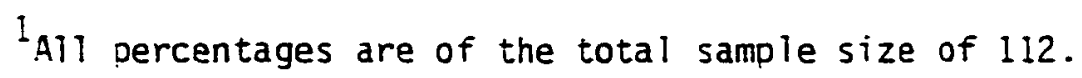

With regard to their formal preparation for teaching, table 3 
shows that 39 ( 33.9 percent) teachers possessed a bachelor's degree, and 58 ( 50.4 percent) a master's degree. Three teachers held doctoral degrees.

TABLE 3

DISTRIBUTION OF HIGHEST EARNED COLLEGE DEGREE
AMONG TEACHERS

\begin{tabular}{lrr}
\hline \multicolumn{1}{c}{ College Degree } & N & Percent \\
\hline No degree & 8 & 7.0 \\
Two-year Teacher's Certificate & 2 & 1.7 \\
Bachelor's degree & 39 & 33.9 \\
Master's degree & 58 & 50.4 \\
Higher degreas & 8 & 7.0 \\
& 115 & 100.0 \\
\hline
\end{tabular}

Table 4 shows that of the 115 teachers more than 60 percent (61.7 percent) graduated from college after 1974 while 28.7 percent obtained their degree between 1965 and 1974. Only three respondents (2.6 percent) graduated from college before 1955 .

\section{ieaching Experience}

Table 5 presents data on the teaching experience of the teachers. This table shows that 36 ( 31.6 percent) of the teachers had taught for no more than four years, 28 (24.3 percent) had up to nine years of teaching, and 23 (20.0 percent) reported fourteen years of teaching experience. The table also shows longer periods of 
teaching. For example, five ( 4.3 percent) reported teaching for at least. twenty-five years, and another five ( 4.3 percent) for at least thirty years. One teacher claimed the record of over thirty-four years of teaching.

TABLE 4

DISTRIBUTION OF COLLEGE GRADUATION DATES AMONG TEACHERS

\begin{tabular}{l|r|c}
\hline DATE & N & Percent \\
\hline Prior to 1950 & 1 & 0.9 \\
$1950-1954$ & 2 & 1.7 \\
$1955-1959$ & 4 & 3.5 \\
$1960-1964$ & 2 & 1.7 \\
$1965-1969$ & 16 & 13.9 \\
$1970-1974$ & 17 & 14.8 \\
$1975-1979$ & 32 & 27.8 \\
After 1979 & 39 & 33.9 \\
Missing & 2 & 1.7 \\
\hline
\end{tabular}

Table 6 presents data on teaching service of the respondents in the present school. An analysis of the data showed that 16 (13.9 percent) had taught for less than one year, 59 (51.3 percent) for one to four years, 20 ( 17.4 percent) for five to eight years, and 12 (10.4 percent) for nine to twelve years. There were only two ( 1.7 percent) teachers who had taught in the same school for at least seventeen 
TABLE 5

DISTRIBUTION OF TEACHERS ACCORDING

TO TEACHING EXPERIENCE

(EXCLUDING THE 1982-1983 SCHOOL YEAR)

\begin{tabular}{c|c|c}
\hline $\begin{array}{c}\text { Years of } \\
\text { Teaching Experience }\end{array}$ & $N$ & Percent \\
\hline $0-4$ & 36 & 31.6 \\
$5-9$ & 28 & 24.3 \\
$10-14$ & 23 & 20.0 \\
$15-19$ & 10 & 8.7 \\
$20-24$ & 6 & 5.2 \\
$25-29$ & 5 & 4.3 \\
$30-34$ & 5 & 4.3 \\
Over 34 & 1 & .9 \\
Missing & 115 & 100 \\
\hline
\end{tabular}

years, and another two ( 1.7 percent) who had served in the present school for at least twenty-one years. Table 6 shows that more than half of the teachers ( 51.3 percent) had taught in the present school for only four or fewer years. On the whole, fewer than two teachers had worked for more than eight years in the same school. This table shows a relatively high rate of teacher mobility in the Lake Union Conference.

Measurement Data on the Instrument

Table 7 shows, for each of the five areas, the reliability 
coefficient of the scale and the discrimination indices (point multiserial correlations) for each of the twelve items in each of the five areas.

All reliability coefficients were satisfactory, ranging from 0.8540 to 0.91 . All point multiserial correlations were also satisfactory, ranging from 0.46 to 0.82 . The data can, therefore, be analyzed with confidence.

TABLE 6

DISTRIBUTION OF TEACHERS ACCORDING TO

TEACHING SERVICE IN THE PRESENT SCHOOL

(EXCLUDING THE 1982-1983 SCHOOL YEAR)

\begin{tabular}{ccc}
\hline $\begin{array}{c}\text { Years of Experience } \\
\text { in Present School }\end{array}$ & $N$ & Percent \\
\hline Less than 1 & 16 & 13.9 \\
$1-4$ & 59 & 51.3 \\
$5-8$ & 20 & 17.4 \\
$9-12$ & 12 & 10.4 \\
$13-16$ & 3 & 2.6 \\
$17-20$ & 2 & 1.7 \\
$21-24$ & 2 & 1.7 \\
Missing & 1 & 0.9 \\
& Total & 115 \\
\hline
\end{tabular}

Descriotive Analysis of Basic Data

on Part II of Questionnaire

This section presents a descriptive analys is of basic data on the second part of the questionnaire according to the following 
categories of teachers: total sample, male, female, teachers possessing master's degrees, teachers with other levels of education, and teachers grouped according to their teaching experience. The presentation is in the form of a narrative and two tables for each category. The first table for each category is shortened to a page in length, except for the total sample whose table appears in full. in the first table for each category, the items (statements) in the second part of the questionnaire are ranked according to the total scores of responses of teachers to each statement. The lowest score an item could receive from a respondent was I (one) and the highest was 5 (five). Then the total score computed from the responses of all the category members to an item is presented in the table as a percentage in a separate column.

The second table for each category shows a rank order of the five functional areas of administration according to a mean weighted score based on the responses of the category members. The mean weighted score was obtained by adding the weighted scores of all the items (statements) in a functional area of administration and dividing the total of the weighted scores by the number of items in that area. Table 8 shows raw scores, weighted scores, and a rank order of the items in the second part of the questionnaire. The rank order is based on the weighted scores which are composed of the total of the responses of all the teachers. The proportion of each weighted score to the full total score for each item $(5 \times 115=575)$ is also given in the table as a percentage. There are eight items whose weighted scores are above 30 percent. They ail belong to one 
TABLE 7

RELIABILITY AND ITEM DISCRIMINATION

\begin{tabular}{|c|c|c|c|c|c|}
\hline \multirow[b]{2}{*}{ Item } & \multicolumn{2}{|c|}{ A } & & \multicolumn{2}{|c|}{ A } \\
\hline & 1 & 2 & 3 & 4 & 5 \\
\hline 1 & $\begin{array}{c}.9043 \\
\star(.7550)\end{array}$ & $\begin{array}{l}.8087 \\
(.7124)\end{array}$ & $\begin{array}{l}.8278 \\
(.5265)\end{array}$ & $\begin{array}{l}.8226 \\
(.6206)\end{array}$ & $\begin{array}{l}.9270 \\
(.7324)\end{array}$ \\
\hline 2 & $\begin{array}{l}.8313 \\
(.7730)\end{array}$ & $\begin{array}{l}.7009 \\
(.4582)\end{array}$ & $\begin{array}{l}.8609 \\
(.8182)\end{array}$ & $\begin{array}{c}.8122 \\
(.6590)\end{array}$ & $\begin{array}{l}.8748 \\
(.7376)\end{array}$ \\
\hline 3 & $\begin{array}{l}.6504 \\
(.5400)\end{array}$ & $\begin{array}{l}.8609 \\
(.5645)\end{array}$ & $\begin{array}{c}.8261 \\
(.7594)\end{array}$ & $\begin{array}{c}.8052 \\
(.7566)\end{array}$ & $\begin{array}{l}.9061 \\
(.7684)\end{array}$ \\
\hline 4 & $\begin{array}{l}.8713 \\
(.7922)\end{array}$ & $\begin{array}{l}.8122 \\
(.6807)\end{array}$ & $\begin{array}{l}.8800 \\
(.8186)\end{array}$ & $\begin{array}{c}.7965 \\
(.5982)\end{array}$ & $(.8539)$ \\
\hline 5 & $\begin{array}{l}.8365 \\
(.7568)\end{array}$ & $\begin{array}{l}.8243 \\
(.5348)\end{array}$ & $\begin{array}{l}.8226 \\
(.7354)\end{array}$ & $\begin{array}{c}.7322 \\
(.5871)\end{array}$ & $(.9043)$ \\
\hline 6 & $\begin{array}{l}.8922 \\
(.5892)\end{array}$ & $\begin{array}{l}.8035 \\
(.6503)\end{array}$ & $\begin{array}{l}.8070 \\
(.5950)\end{array}$ & $\begin{array}{l}.7322 \\
(.7334)\end{array}$ & $\begin{array}{l}.9548 \\
(.5760)\end{array}$ \\
\hline 7 & $\begin{array}{l}.8557 \\
(.7496)\end{array}$ & $\begin{array}{l}.8104 \\
(.7250)\end{array}$ & $\begin{array}{l}.8087 \\
(.7693)\end{array}$ & $(.6661)$ & $\begin{array}{l}.9426 \\
(.6549)\end{array}$ \\
\hline 8 & $\begin{array}{l}.8487 \\
(.7508)\end{array}$ & $\begin{array}{l}.8296 \\
(.7214)\end{array}$ & $\begin{array}{l}.8278 \\
(.8107)\end{array}$ & $\begin{array}{l}.8243 \\
(.5845)\end{array}$ & $(.8817)$ \\
\hline 9 & $\begin{array}{l}.8017 \\
(.5636)\end{array}$ & $\begin{array}{c}.8191 \\
(.5958)\end{array}$ & $\begin{array}{c}.8939 \\
(.7333)\end{array}$ & $\begin{array}{l}.7774 \\
(.7124)\end{array}$ & $\begin{array}{c}.8452 \\
(.7390)\end{array}$ \\
\hline 10 & $\begin{array}{l}.7913 \\
(.6653)\end{array}$ & $\begin{array}{l}.7930 \\
(.6911)\end{array}$ & $\begin{array}{l}.8730 \\
(.6186)\end{array}$ & $\begin{array}{l}.7496 \\
(.7247)\end{array}$ & $\begin{array}{l}.9043 \\
(.7571)\end{array}$ \\
\hline 11 & $\begin{array}{r}8800 \\
(7937)\end{array}$ & $(.6661)$ & $\begin{array}{c}.7983 \\
(.7271)\end{array}$ & $\begin{array}{l}.8504 \\
(.6067)\end{array}$ & $(.9061)$ \\
\hline 12 & $\begin{array}{l}.7861 \\
(.6976)\end{array}$ & $\begin{array}{l}.7878 \\
(.6057)\end{array}$ & $\begin{array}{l}.8383 \\
(.7022)\end{array}$ & $\begin{array}{c}.8296 \\
(.5755)\end{array}$ & $\begin{array}{c}.9061 \\
(.6719)\end{array}$ \\
\hline $\begin{array}{l}\text { Reliab } \\
\text { Coeff. }\end{array}$ & 9026 & 540 & 9100 & .8600 & 9100 \\
\hline
\end{tabular}

*The point multi-serial correlation is shown in parentheses below each proportional score for an individual. 
TABLE 8

ALL IEACHERS' PERCEPTIONS OF ACAUEHYY PIIINCIPAL.'S EFFECTIVENESS

BY RAIIKED ITEH

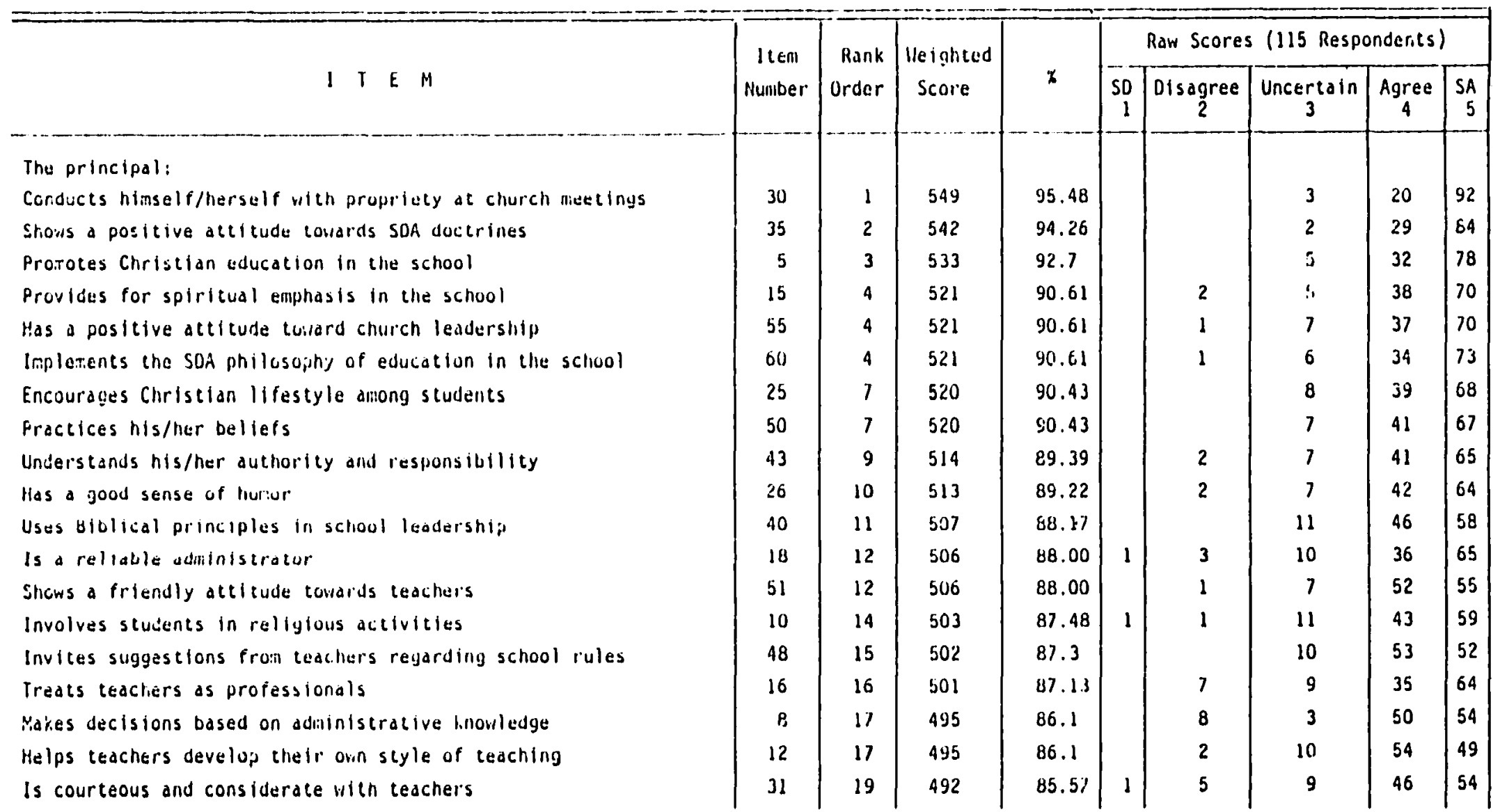


TABLE 8-Conthaned

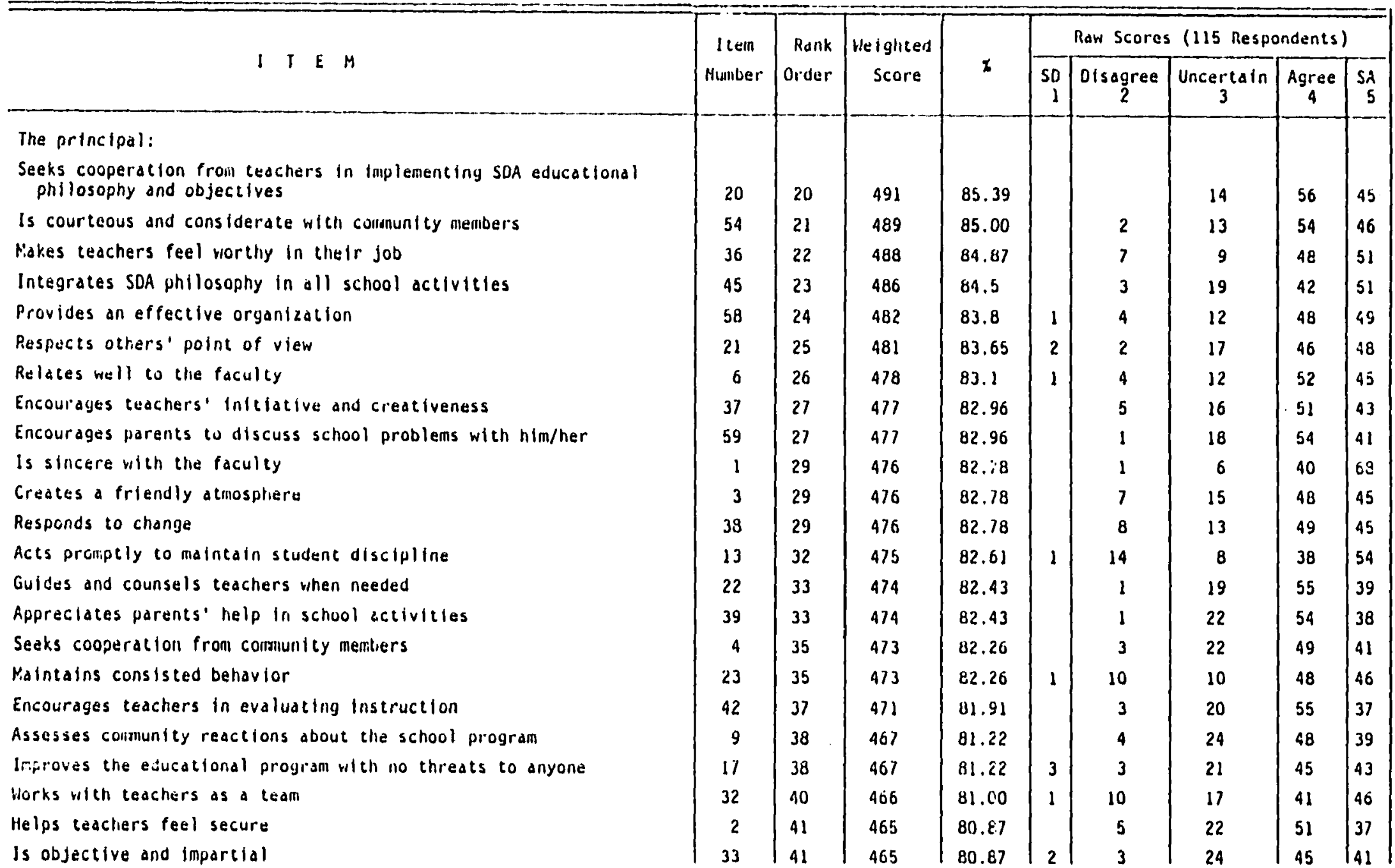


TAOLE 8-Continued

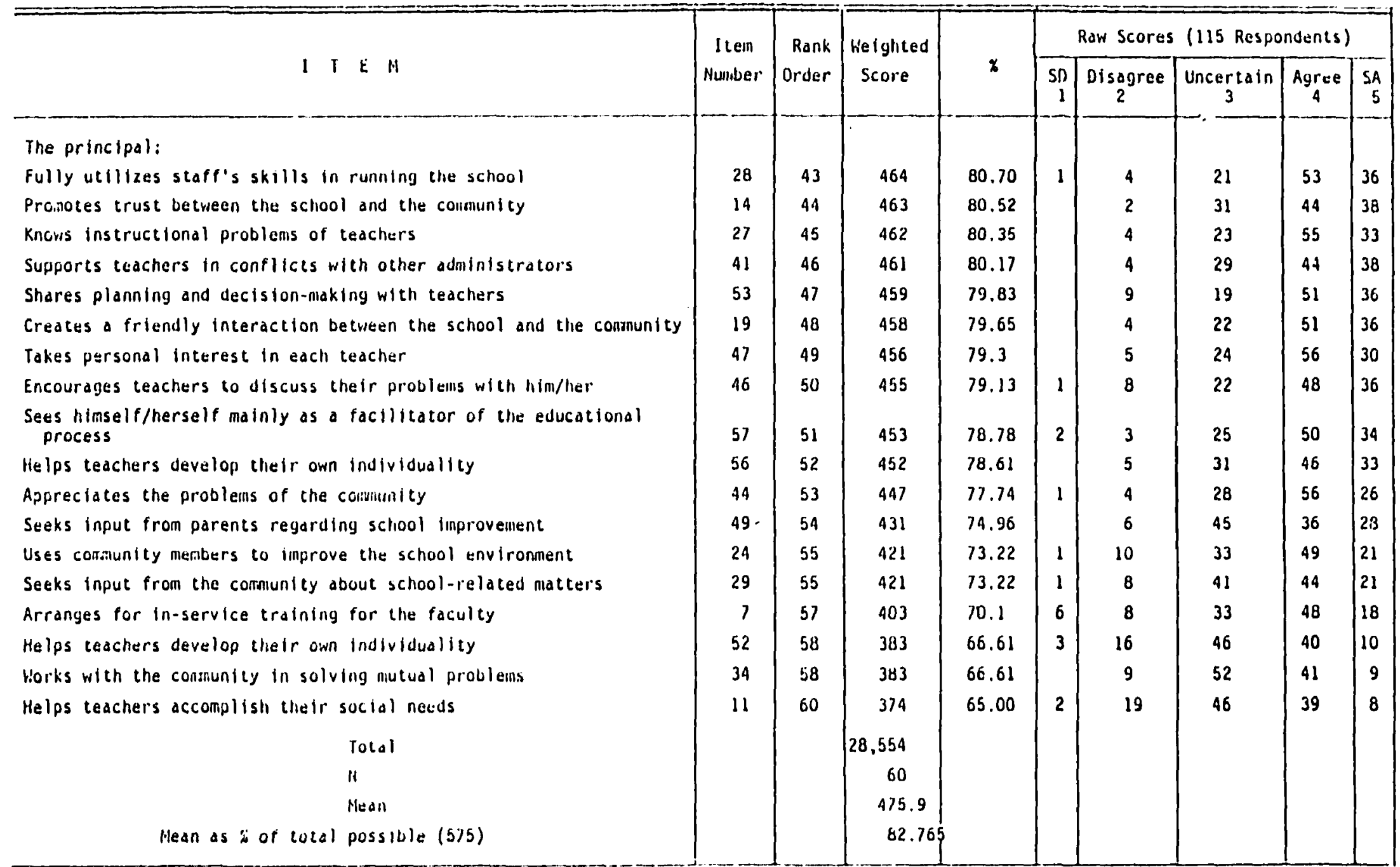


functional area of administration, namely, the spiritual climate.

This shows that the respondents strongly agreed that the academy orincipal was most effective in this area.

In the 85-90 percent range, there are thirteen items representing all the five areas. The area of school management is represented by four of these thirteen items. Thus the next area in which the principal was perceived to be effective is that of school management.

Table 9 gives the rank order and the mean weighted scores of the five areas of administration. For each area, the maximum possible mean weighted score is again $5 \times 115=575$. The rank order and the mean weighted scores are based on the responses of ail the teachers. They include male and female teachers. Over 20 percent of these possess college degrees. Some of these teachers have taught for less

TABLE 9

FUNCTIONAL ADMINSITRATIVE AREAS RANKED

ACCORDING TO THE MEAN BASED

ON ALL TEACHERS' RESPONSES

\begin{tabular}{lcc}
\hline $\begin{array}{l}\text { Functional } \\
\text { Administrative } \\
\text { Area }\end{array}$ & $\begin{array}{l}\text { Rank } \\
\text { Order }\end{array}$ & $\begin{array}{c}\text { Mean } \\
\text { Weighted } \\
\text { Score }\end{array}$ \\
\hline Soiritual climate & 1 & 517.83 \\
School Management & 2 & 482.25 \\
Staff-principal Relations & 3 & 473.08 \\
Curriculum and Instruction & 4 & 456.00 \\
School Community Relations & 5 & 450.33 \\
\hline
\end{tabular}


than one year. Others have taught for one to five years, and still others for more than five years. The perceptions of each of these groups regarding the principal are discussed later.

Table 10 shows raw scores and a rank order of the items in the second part of the questionnaire on the part of males. The rank order is based on the weighted scores which are computed from the responses of all the male teachers. The maximum possible score here is $5 \times 71=355$. The proportion of each weighted score to the full total score for each item is aiso indicated in the table as a percentage. All the items in the 90-95 percent range relate to the spiritual leadership of the principal in the school. Thus the area that ranked highest was that of spiritual climate. The next highest area was that of school management.

Of the ten last items in the 63-79 percentage range, five refer to the principal's interaction with the community. The male respondents perceived the principal to be least effective in this interaction.

Table 11 shows the rank order and the mean weighted scores of the five areas of administration based on the responses of male teachers. The rank order and the mean weighted scores are based on the male teachers' responses. Again, the maximum possible mean is 355.

Table 12 gives raw scores, weighted scores, and a rank order of the items in the second part of the questionnaire on the part of 


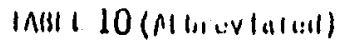

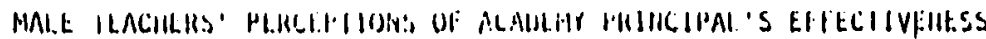
BY KAMIRLOD ITEM

\begin{tabular}{|c|c|c|c|c|c|c|c|c|c|}
\hline \multirow[b]{2}{*}{$\begin{array}{llll}I & \mathrm{I}\end{array}$} & \multirow[b]{2}{*}{$\begin{array}{c}\text { Itein } \\
\text { Numilser }\end{array}$} & \multirow[b]{2}{*}{ 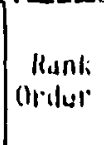 } & \multirow[b]{2}{*}{ 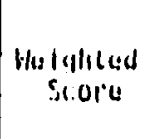 } & \multirow[b]{2}{*}{$x$} & \multicolumn{5}{|c|}{ Raw Scores (71 Respondents) } \\
\hline & & & & & $\begin{array}{r}\text { SD } \\
1\end{array}$ & $\underset{2}{\text { Disaugree }}$ & $\underset{3}{\text { Uncertain }}$ & $\begin{array}{c}\text { Agree } \\
4\end{array}$ & $\begin{array}{r}5 A \\
5\end{array}$ \\
\hline The principal & & & & & & & & & \\
\hline Conducts himself/herself with propriaty at church inetings & 30 & 1 & 336 & 94.65 & & & 3 & 13 & 55 \\
\hline Shows a positive attltude towards SOA Joctrines & 35 & 2 & 334 & 94.08 & & & 2 & 17 & 52 \\
\hline Promotes Christian education in the schoul & 5 & 3 & 329 & 92.68 & & & 2 & 22 & 47 \\
\hline Encourages Christian Iffestyle ainong studenls & 25 & 4 & 323 & so. 99 & & & 3 & 26 & 42 \\
\hline Has a positive attitude toriards church leadership & 55 & 5 & 322 & 90.70 & & & 5 & 23 & 43 \\
\hline Provides for spirlcual eniphasis in the school & 25 & 6 & 320 & 90.14 & & 2 & 1 & 27 & 41 \\
\hline Practices his/har bellefs & 50 & 7 & 318 & 89.58 & & & 5 & 27 & 39 \\
\hline Is sincere with the faculty & 1 & 8 & 317 & 89.30 & & 1 & 4 & 27 & 39 \\
\hline Understands his/her authority and responsibility & 43 & 8 & 317 & 89.30 & & 1 & 3 & 29 & 38 \\
\hline Implements the SOA phrlosophy of educstion in the school & 60 & 10 & 316 & 89.01 & & & 5 & 24 & 41 \\
\hline Vitus himself/herself primarlly as a facilitator & 57 & 53 & 276 & 77.75 & 2 & 2 & 13 & 34 & 19 \\
\hline Seelis input from parents regarding school improveinent & 49 & 54 & 262. & 73.80 & & 5 & 29 & 20 & 17 \\
\hline Seeks indout frum the comnunity about school-related matters. & 29 & $5 j^{\prime}$ & 257 & 72.39 & & 6 & 26 & 28 & 11 \\
\hline Uses combinnity members to hmurove the school environnent & 24 & 56 & 253 & 71.27 & & 9 & 21 & 28 & 12 \\
\hline Arranges for in-service training for the faculty & 7 & $5 ?$ & 247 & 69.58 & 3 & 6 & 19 & 30 & 11 \\
\hline Helps teachers accomplish their soctal needs & 11 & 58 & 237 & 66.76 & & 10 & 32 & 24 & 5 \\
\hline Helps teachers orjanize teaching tasks economically & 52 & 59 & $234^{\circ}$ & 65.92 & 3 & 9 & 29 & 24 & 6 \\
\hline Horks with the comenunlty in solving nutual problens & 34 & 60 & 227 & 63.94 & & 6 & 31 & 28 & 2 \\
\hline
\end{tabular}


TABLE 11

FUNCTIONAL ADMINISTRATIVE AREAS RANKED

ACCORDING TO THE MEAN BASED

ON MALE TEACHERS' RESPONSES

\begin{tabular}{lcc}
\hline $\begin{array}{l}\text { Functional } \\
\text { Administrative } \\
\text { Area }\end{array}$ & $\begin{array}{c}\text { Rank } \\
\text { Order }\end{array}$ & $\begin{array}{c}\text { Mean } \\
\text { Weighted } \\
\text { Score }\end{array}$ \\
\hline Spiritual Climate & 1 & 317.92 \\
School Management & 2 & 297.1 \\
Staff-Principal Relations & 3 & 292.17 \\
Curriculum and Instruction & 4 & 278.17 \\
School-Curriculum Relations & 5 & 275.17 \\
\hline
\end{tabular}

44 female teachers. The rank order is based on the weighted scores which were computed from the responses of all the female teachers. The maximum possible score is $5 \times 44=220$. The proportion of each weighted score for each item is also shown in the table as a percentage.

Table 13 shows the rank order and mean weighted scores of the five areas of administration. The rank order and the mean weighted scores were based on the female teachers' responses. The maximum possible mean score is 220.

Table 14 gives raw scores, weighted scores based on responses of teachers with master's degrees, and a rank order of the items in the second part of the questionnaire. The maximum possible score is $5 \times 58=290$. The column next to that for the weighted scores shows the obtained score as a percentage of the full total score for 
TABLLE 12 (Aubreviated)

fEMALE tEACIERS' PERCERTIONS OF ACADENY PRIICIPAL.'S EFFECTIVENESS BY RAIKED ITEM

\begin{tabular}{|c|c|c|c|c|c|c|c|c|c|}
\hline \multirow{2}{*}{$\begin{array}{llll}1 & T & E & M\end{array}$} & \multirow{2}{*}{$\begin{array}{c}\text { Itein } \\
\text { Nuniber }\end{array}$} & \multirow{2}{*}{$\begin{array}{l}\text { Rank } \\
\text { Order }\end{array}$} & \multirow{2}{*}{$\begin{array}{l}\text { Weighted } \\
\text { Score }\end{array}$} & \multirow[b]{2}{*}{$x$} & \multicolumn{5}{|c|}{ Raw Scores (44 Respondents) } \\
\hline & & & & & $\begin{array}{c}\text { so } \\
1\end{array}$ & Disagree & $\begin{array}{c}\text { Uncertain } \\
3\end{array}$ & $\underset{4}{\mathrm{Agree}}$ & $\begin{array}{c}S A \\
5\end{array}$ \\
\hline \multicolumn{10}{|l|}{ The principsl } \\
\hline Conducts hiriself/herself with propriety at church meetings & 30 & 1 & 213 & 96.82 & & & & 7 & 31 \\
\hline Sho:s a positive attltude towards SDA doctrines & 35 & 2 & 208 & 94.55 & & & & 12 & 32 \\
\hline Impl:ments the SDA philosophy of education in the school & 60 & 3 & 205 & 93.18 & & 1 & 1 & 10 & 32 \\
\hline Prolinites Christian education in the school & 5 & 4 & 204 & 92.73 & & & 3 & 10 & 31 \\
\hline Is s'ncere with the foculty & 1 & 5 & 203 & 92.27 & & & 2 & 13 & 29 \\
\hline Has a good sense of hurrior & 26 & 5 & 203 & 92.27 & & & 2 & 13 & 29 \\
\hline Practices his/her beliefs & 50 & 7 & 202 & 91.82 & & & 2 & 14 & 28 \\
\hline Provices for spirltual empliasis in the schiool & 15 & 8 & 201 & 91.36 & & & 4 & 11 & 29 \\
\hline Sions a friendly altitude conard teachers & 31 & 9 & 200 & 90.91 & & 1 & 1 & 18 & 24 \\
\hline has a positive attitude toward church leadarship & 55 & 10 & 199 & 90.45 & & 1 & 2 & 14 & 27 \\
\hline incourages Christian Lifestyle among students & 25 & 11 & 197 & $89 . .55$ & & & 5 & 13 & 26 \\
\hline Uses Eiblical principles in school leadership & 40 & 11 & 197 & 89.55 & & & 4 & 15 & 25 \\
\hline Aporeciates the prosleris of the corinnunicy & 44 & 53 & 170 & 77.27 & & 2 & 15 & 14 & 13 \\
\hline Secks ingut from parents regarding school improvement & 49 & 34 & 169 & 76.82 & & 1 & 16 & 16 & 11 \\
\hline Uses cornunity memters to improve the school environment & 24 & 55 & 168 & 76.36 & 1 & 1 & 12 & 21 & 9 \\
\hline Seeks input from the conmunity about school-related matters & 29 & 56 & 164 & 74.55 & 1 & 2 & 15 & 16 & 10 \\
\hline Arronges for in-service training for the faculty & 7 & 57 & 156 & 70.91 & 3 & 2 & 14 & 18 & 7 \\
\hline biorks with the comomunity in solving mitual probleills & 34 & 57 & 156 & 70.91 & & 3 & 21 & 13 & 7 \\
\hline Helps teactiers organize teaching lasks ecunomically & 52 & $5 \dot{y}$ & 149 & 67.73 & & 7 & 17 & 16 & 4 \\
\hline Helps teachers accomplish thatr social needs & 11 & 60 & 137 & 62.20 & 2 & 9 & 14 & 15 & 3 \\
\hline
\end{tabular}


TABLE 13

\section{FUNCTIONAL ADMINISTRATIVE AREAS RANKED ACCOROING TO THE MEAN BASED ON \\ FEMALE TEACHERS' RESPONSE}

\begin{tabular}{lcc}
\hline $\begin{array}{l}\text { Functional } \\
\text { Administrative } \\
\text { Area }\end{array}$ & $\begin{array}{c}\text { Rank } \\
\text { Order }\end{array}$ & $\begin{array}{c}\text { Mean } \\
\text { Weighted } \\
\text { Score }\end{array}$ \\
\hline Spiritual Climate & 1 & 199.92 \\
School Management & 2 & 185.17 \\
Staff-Principal Relations & 3 & 184.67 \\
Curriculum and Instruction & 4 & 177.83 \\
School Community Relations & 5 & 175.17 \\
\hline
\end{tabular}

each item. There are thirteen items whose wejghted scores are in the 90-97 percentage range. Eight of these items represent the spiritual climate. Thus most of the respondents strongly agreed that the academy principal was highly effective in this area.

Table 15 shows the rank order and mean weighted scores of the five areas of administration. The rank order and the mean weighted scores are based on the responses of teachers with master's degrees. The maximum possible mean is $5 \times 58=290$.

According to this table, the rank order of the five functional areas of administration does not differ from the way the areas have been ranked for the male or the female respondents. These teachers with master's degrees strongly agreed that the principal was highly effective in the area of spiritual climate but least effective in 
IABLE 14 (ALDrevlated)

PERCEPIIONS OF TEACIIERS (WITH M.A. OEGREE) OF ACADEMY PRINCIPAL'S EFFECTIVENESS BY RAIIKED ITEH

\begin{tabular}{|c|c|c|c|c|c|c|c|c|c|}
\hline \multirow{2}{*}{$I T E M$} & \multirow{2}{*}{$\begin{array}{c}\text { Itelli } \\
\text { Humber }\end{array}$} & \multirow{2}{*}{$\begin{array}{l}\text { Rank } \\
\text { Order }\end{array}$} & \multirow{2}{*}{$\begin{array}{l}\text { Weighted } \\
\text { Score }\end{array}$} & \multirow{2}{*}{ z } & \multicolumn{5}{|c|}{ Raw Scores (58 Respondenis) } \\
\hline & & & & & SD & Oisagree & $\begin{array}{c}\text { Uncertain } \\
3\end{array}$ & $\underset{4}{\text { Agree }}$ & $\begin{array}{r}S A \\
5\end{array}$ \\
\hline The princtpal & & & & & & & & & \\
\hline Conducts himself/herself will propriety ot church meetings & 30 & 1 & 281 & 96.90 & & & & 9 & 49 \\
\hline Shows a positive attltude towards SDA doctrines & 35 & 2 & 276 & 95.17 & & & & 14 & 44 \\
\hline Promotes Christian education in the school & 5 & 3 & 271 & 93.45 & & & 2 & 15 & 41 \\
\hline Has a positive attitude toward church leadership & 55 & 3 & 271 & 93.45 & & & 2 & 15 & al \\
\hline is sincere wilen the faculty & 1 & 5 & 267 & 92.07 & & 1 & 1 & 18 & 38 \\
\hline Practices lits/her betlefs & 50 & 5 & 267 & 92.07 & & & 2 & 19 & 37 \\
\hline Provides for spiritud elliphasis in the schicol & 15 & 7 & 265 & 91.38 & & 1 & 2 & 18 & 37 \\
\hline Implements the SDA philosophy of education in the schoul & 60 & 8 & 264 & 91.03 & & & 4 & 13 & 40 \\
\hline Is a reliable adininistrator & 18 & 9 & 263 & 90.69 & & & 4 & 19 & 35 \\
\hline Encouragas Christian lifestyle amiony seudents & 25 & 9 & 263 & 90.69 & & & 4 & 19 & 35 \\
\hline Understands his/her autliority and responsibillity & 43 & 9 & 263 & $90^{\circ} .69$ & & & 3 & 21 & 34 \\
\hline Has a good sense of humor & 26 & 12 & 261 & 90.00 & & & 1 & 27 & 38 \\
\hline Shows a friendly attitude towards teachers & 51 & 12 & 261 & 90.00 & & & 1 & 27 & 30 \\
\hline Secks input fron parents legarding scrioul inprovement & 49 & 54 & 221 & 76.21 & & 3 & 20 & 20 & 15 \\
\hline Uses comunity meinbers to hilprove the sctiool unviraninent & 24 & 55 & 216 & 74.48 & & 3 & 21 & 23 & 11 \\
\hline Seeks input from the comriunity about school-related matters & 29 & 56 & 215 & 74.14 & & 1 & 24 & 24 & 9 \\
\hline Arranges for in-service training for the faculty & 7 & 57 & 199 & 68.62 & 5 & 4 & 16 & 22 & 10 \\
\hline Helps teachers organize teaching tasks economically & 52 & 58 & 198 & $68.2 E$ & 2 & 4 & 24 & 24 & 4 \\
\hline
\end{tabular}


TABLE 15

FUNCTIONAL AOMINISTRATIVE AREAS RANKED ACCORDING

TO THE MEAN BASED ON RESPONSES OF

TEACHERS WITH M.A. DEGREE

\begin{tabular}{lcc}
\hline $\begin{array}{l}\text { Functional } \\
\text { Administrative } \\
\text { Area }\end{array}$ & $\begin{array}{c}\text { Rank } \\
\text { Order }\end{array}$ & $\begin{array}{c}\text { Mean } \\
\text { Weighted } \\
\text { Score }\end{array}$ \\
\hline Spiritual Climate & 1 & 264.67 \\
School Management & 2 & 248.58 \\
Staff-Principal Relations & 3 & 244.33 \\
Curriculum and Instruction & 4 & 232.17 \\
School-Community Relations & 5 & 228.42 \\
\hline
\end{tabular}

his/her relations with the school community.

Table 16 shows raw scores, weighted scores based on responses of the teachers with levels of education other than a master's degree, and a rank order of the items in the second part of the questionnaire. The maximum possible mean is $5 \times 57=285$. The column next to that for the weighted scores shows the obtained score as a percentage of the full total score for each item. There are twelve items whose weighted scores are ranked above 37 percent. iline of these belong to the functional area of spiritual climate. This indicates that the respondents strongly agreed that the academy principal was most effective in this area.

in the 64-74 percent range. the area of school-community 
TAUIE 16 (AGUreviated)

PERCEPTIONS OF TEACHERS (WITH OTHER LEVELS OF EDUCATION) OF ACADEMY PRINCIPAL'S EFFECTIVENESS BY RANKED ITEH

\begin{tabular}{|c|c|c|c|c|c|c|c|c|c|}
\hline \multirow[b]{2}{*}{$1 T$ E H } & \multirow{2}{*}{$\begin{array}{c}\text { Item } \\
\text { Number }\end{array}$} & \multirow{2}{*}{$\begin{array}{r}\text { Rank } \\
\text { Order }\end{array}$} & \multirow{2}{*}{$\begin{array}{c}\text { Weighted } \\
\text { Score }\end{array}$} & \multirow{2}{*}{$\boldsymbol{x}$} & \multicolumn{5}{|c|}{ Raw Scores (57 Respondents) } \\
\hline & & & & & SD & $\begin{array}{c}\text { Disagree } \\
2\end{array}$ & $\underset{3}{\text { Uncertain }}$ & $\underset{4}{\text { Agree }}$ & $\begin{array}{c}S A \\
5\end{array}$ \\
\hline The Principal & & & & & & & & & \\
\hline Conducts himself/herself with propriety at church meetings & 30 & 1 & 268 & 94.00 & & & 3 & 11 & 43 \\
\hline Shows a positive attitude towards SDA doctrines & 35 & 2 & 266 & 93.33 & & & 2 & 15 & 40 \\
\hline Promstes Christian education fn the school & s & 3 & 262 & 91.93 & & & 3 & 17 & 37 \\
\hline Encourages Christian lifestyle among students & 25 & 4 & 257 & 90.18 & & & 4 & 20 & 33 \\
\hline In:pletients the SDA philosophy of education in the school & 60 & 4 & 257 & 90.18 & & 1 & 2 & 21 & 33 \\
\hline Provides for spiritual emphas is in the school & 15 & 6 & 256 & 89.82 & & 1 & 3 & 20 & 33 \\
\hline Is sincere with the faculty & 1 & 7 & 253 & 88.77 & & & 5 & 22 & 30 \\
\hline Practices his/her bellefs & 50 & 7 & 253 & 88.77 & & & 5 & 22 & 30 \\
\hline Has a good sense of humor & 26 & 9 & 252 & 80.42 & & 2 & 6 & 15 & 34 \\
\hline Understands his/her authority and responsibility & 43 & 10 & 251 & 88.10 & & 2 & 4 & 20 & 31 \\
\hline Has a pasitive attitude tonard church leadership & 55 & 11 & 250 & 87.12 & & 1 & 5 & 22 & 29 \\
\hline Seeks input from parents regarding schoul improventent & 49 & 54 & 210 & 73.68 & & 3 & 25 & 16 & 13 \\
\hline Seeks input from the combunily atsout schoui-retated maters & 29 & 55 & 206 & 72.28 & 1 & 7 & 17 & 20 & 12 \\
\hline Lises communfly menibers to inipruve the schoul enviromment & 24 & 56 & 205 & 71.93 & 1 & 7 & 12 & 26 & 10 \\
\hline Arranges for in-service lraining for the fuculty & 7 & 57 & 204 & 71.58 & 1 & 4 & 17 & 26 & 8 \\
\hline Horks with the conmunity in solving mutual probleills & 34 & 58 & 199 & 69.82 & & 5 & 24 & 23 & 5 \\
\hline Helps teachers accomplish their social needs & 11 & 59 & 189 & 66,32 & 2 & 9 & 21 & 19 & 6 \\
\hline Melps teachers organize tedching tasks econointcally & 52 & 60 & 185 & 64.91 & 1 & 12 & 22 & 16 & 6 \\
\hline
\end{tabular}


relations is represented by four of the seven items. Table 17 shows the rank order and mean weighted scores of the five areas of administration. The rank order and the mean weighted scores were based on the responses of teachers with ievels of education other chan a master's degree. The maximum possible mean is $5 \times 57=285$. Thus the school-comunity relations area was last in the rank order, showing that the principal was perceived to be least effective in his/ her relations with the school community.

TABLE 17

FUNCTIONAL ADMINISTRATIVE AREAS RANKED ACCORDING TO THE MEAN BASED ON RESPONSES OF TEACHERS WITH OTHER LEVELS OF EDUCATION

\begin{tabular}{lcc}
\hline $\begin{array}{l}\text { Functional } \\
\text { Administrative } \\
\text { Area }\end{array}$ & $\begin{array}{c}\text { Rank } \\
\text { Order }\end{array}$ & $\begin{array}{c}\text { Mean } \\
\text { Neighted } \\
\text { Score }\end{array}$ \\
\hline Spiritual Climate & 1 & 253.17 \\
School Management & 2 & 233.67 \\
Staff-Principal Relations & 3 & 231.00 \\
Curriculum and Instruction & 4 & 223.67 \\
School-Community Relations & 5 & 221.92 \\
\hline
\end{tabular}

Table 18 presents raw scores, weighted scores based on responses of the teachers with 1-4 years of teaching experience, and rank order of the items in the second part of the questionnaire. The maximum possible score is $5 \times 36=180$. The column next to that for the weighted scores shows the obtained score as a percentage of the 
IAGLE 18 (Aburevidated)

PERCEPTIONS OF TEACHERS (WITH I-4 YEARS TEACHING EXPERIENICE)

OF PRINCIPAI. 'S EFFECTIVENESS BY RAIIKEO ITEM

\begin{tabular}{|c|c|c|c|c|c|c|c|c|c|}
\hline \multirow{2}{*}{$I T E M$} & \multirow{3}{*}{$\begin{array}{c}\text { It } t \in \| 11 \\
\text { Number }\end{array}$} & \multirow{2}{*}{$\begin{array}{c}\text { Rank: } \\
\text { Ordiar }\end{array}$} & \multirow{2}{*}{$\begin{array}{c}\text { Weighted } \\
\text { Score }\end{array}$} & \multirow[b]{2}{*}{$x$} & \multicolumn{5}{|c|}{ Raw Scores (36 Respondents) } \\
\hline & & & & & $\begin{array}{c}\text { SD } \\
1\end{array}$ & $\underset{2}{D i s a g r e e}$ & $\underset{3}{\text { Uncertain }}$ & $\begin{array}{c}\text { Aglece } \\
4\end{array}$ & $\begin{array}{r}5 A \\
5\end{array}$ \\
\hline The principal & & & & & & & & & \\
\hline Conducts himself/herself with propriety at church meetings & 30 & 1 & 166 & 92.2 & & & 3 & 8 & 25 \\
\hline Shoris a positive attltude turards SDA doctrines & 35 & 2 & 165 & 91.67 & & & 1 & 13 & 22 \\
\hline Provides for spiritual emphasis in the school & 15 & 3 & 164 & 91.11 & & & 2 & 12 & 22 \\
\hline Proniotes Christian education in the school & 5 & 4 & 163 & 90.56 & & & 3 & 11 & 22 \\
\hline Implenents the SDA philosophy of education in the school & 60 & 4 & 163 & 90.56 & & & 2 & 13 & 21 \\
\hline Encourages Christidn lifestyle ditongl studencs & 25 & 6 & 160 & 48.89 & & & 3 & 14 & 19 \\
\hline Helps teachers accomplish their social needs & 12 & 7 & 158 & 87.78 & & & 2 & 18 & 16 \\
\hline Has a positive ottitude tovard church leadership & 55 & 7 & 158 & 81.78 & & 1 & 3 & 13 & 19 \\
\hline Practices his/her bellefs & 50 & 9 & 156 & 86.67 & & & 4 & 16 & 16 \\
\hline lias a good sense of humor & 26 & 10 & 155 & $\$ 6.11$ & & 2 & 4 & 11 & 19 \\
\hline Understands his/her duthority and responsibllity & 13 & 11 & 154 & 85,56 & & 1 & 3 & 17 & 15 \\
\hline Uses Eiblical prificiples in school leadershtp & 40 & 12 & 153 & 85.00 & & & 6 & 15 & 15 \\
\hline Integrates SOA philosophy in all school activities & 45 & 12 & 153 & 85.00 & & & 9 & 9 & 18 \\
\hline Is objective and impartial & 33 & 53 & 132 & 73.33 & 1 & 3 & 12 & 11 & 9 \\
\hline Uses cariliunity members to improve the school enviromment & 24 & 55 & 131 & 72.78 & & 3 & 12 & 16 & 5 \\
\hline Seahs input froil parents regarding school inprovement & 49 & 56 & 128 & 71.11 & & 3 & 15 & 13 & 5 \\
\hline Sasks linput from the contiunity about school-related matcers & 29 & 57 & 126 & 70.00 & & 4 & 13 & 16 & 3 \\
\hline Helos teachers accomplish their social needs & 11 & 38 & 119 & 66.11 & 1 & 6 & 15 & 9 & 5 \\
\hline Horks with the combunity in solving mutusl problems & 34 & 59 & 118 & 65.56 & & 2 & 17 & 12 & 3 \\
\hline
\end{tabular}


full total score for each item. All the items in the 30-percent range belong to the area of spiritual climate. This shows

that the respondents strongly agreed that the academy principal was most effective in this area.

In the 80-90-percent range, there are twenty-seven items.

Seven of these belong to the spiritual climate area. Of the twenty items left, items $43,48,58,18,8$, and 38 belong to the area of school management. The other three areas are represented by fewer items in this percentage range. This shows that school management was the next area in which the principal was perceived to be effective in the leadership of the school.

In the 65-75-percent range, ten items are inciuded. Uf these, items $44,24,49,29$, and 34 describe a princidal's behavior in his interaction with community members. The respondents perceived the principal to be least effective in this respect.

Table 19 shows the rank order and the mean weighted scores of the five areas of administration. The rank order and the mean weighted scores were based on the responses of teachers with 1-4 years of teaching experience.

Table 20 presents raw scores, weighted scores based on responses of teachers with 5-9 years of teaching experience, and a rank order of the items in the second part of the questionnaire. The maximum possible score is $5 \times 28=140$. The column next to that for the weighted scores shows the obtained score as a percentage of the full total score for each item. Of the eight items in the 90-98percent range, five belong to the area of spiritual climate. This 
indicates that the respondents strongly agreed that the academy principal was most effective in this area.

\section{TABLE 19}

FUNCTIONAL ADMINISTRATIVE AREAS RANKED ACCORDING

TO THE MEAN BASED ON RESPONSES OF TEACHERS

WITH 1-4 YEARS TEACHING EXPERIENCE

\begin{tabular}{lcc}
\hline $\begin{array}{l}\text { Functional } \\
\text { Administrative } \\
\text { Area }\end{array}$ & $\begin{array}{c}\text { Rank } \\
\text { Order }\end{array}$ & $\begin{array}{c}\text { Mean } \\
\text { Weighted } \\
\text { Score }\end{array}$ \\
\hline Spiritual Climate & 1 & 158.67 \\
School Management & 2 & 143.25 \\
Staff-Principal Relations & 3 & 142.67 \\
Curricuium and Instruction & 4 & 139.1 \\
School-Community Relations & 5 & 137.5 \\
\hline
\end{tabular}

in the 80-90-percent range, there are thirty-eight items.

Seven of these belong to the spiritual climate aroa which was ranked first.

Table 21 shows the rank order and the mean weighted score of the five areas of administration. The rank order and the mean weighted scores are based on the responses of teachers with 5-9 years of teaching experience. The maximum possible mean is $5 \times 28=140$. School management was ranked second, and the area of school-community relations was ranked fifth. 
TAULE 20 (ADDreviated)

PERCEPTIOHS OF TEACHERS (WITH $5-9$ YEARS TEACHING EXPERIENCE) OF PRINCIPAL'S EFFECTIVENESS BY RAIIKED ITEM

\begin{tabular}{|c|c|c|c|c|c|c|c|c|c|}
\hline \multirow[b]{2}{*}{ I I E H } & \multirow{2}{*}{$\begin{array}{c}\text { ltein } \\
\text { Number }\end{array}$} & \multirow{2}{*}{$\begin{array}{l}\text { Rank } \\
\text { Order }\end{array}$} & \multirow{2}{*}{$\begin{array}{l}\text { heighted } \\
\text { Score }\end{array}$} & \multirow{2}{*}{$x$} & \multicolumn{5}{|c|}{ Raw Scores (28 Respondents) } \\
\hline & & & & & SO & $\underset{2}{\text { Disdgree }}$ & $\begin{array}{c}\text { Uncerta in } \\
3\end{array}$ & $\underset{4}{\text { Agree }}$ & $\begin{array}{r}S A \\
5\end{array}$ \\
\hline The principal & & & & & & & & & \\
\hline Conducts himself/herself with proprtety at church meetinys & 30 & 1 & 137 & $9 \% .86$ & & & & 3 & 25 \\
\hline Shows a positive attitude towards SDA doctrines & 35 & 2 & 132 & 94.29 & & & 1 & 6 & 21 \\
\hline Is sincere with the foculty & 1 & 3 & 131 & 93.57 & & & & 9 & 19 \\
\hline Promotes Christian education in the schuol & 5 & 4 & 129 & 92.14 & & & 2 & 7 & 19 \\
\hline Practicas his/her bellefs & 50 & 4 & 129 & 92.14 & & & 1 & 9 & 18 \\
\hline Unterstands his/her authorlty and responstollity & 43 & 6 & 127 & 90.71 & & 1 & 2 & 6 & 19 \\
\hline Nlas a yood sense of hunior & 26 & 1 & 126 & 90.00 & & & 1 & 12 & 15 \\
\hline Has a postcive attitude toward clurch leaderslifip & 55 & 7 & 126 & 90.00 & & & 3 & 8 & 17 \\
\hline Improves the educational program with no threats to anyone & 17 & 49 & 109 & 77.86 & 2 & & 7 & 9 & 10 \\
\hline Encourdges teachers to discuss thelr problenis with hinilher & 46 & 49 & 109 & 71.86 & & 3 & 6 & 10 & 9 \\
\hline Encourages teachers in evaluating instruction & 42 & 51 & 108 & 77.14 & & 3 & 6 & 11 & B \\
\hline Appreciates the problems of the commlinity & 44 & 51 & 108 & 77.14 & & 3 & 7 & 9 & 9 \\
\hline Secks input from parenes regarding schiool tulprovellint & 49 & 53 & 107 & 76.43 & & 2 & 9 & 9 & 8 \\
\hline Helps teachers develop their own individuality & $50 ́$ & 53 & 107 & 76.43 & & 2 & 9 & 9 & 8 \\
\hline Seeks input fron the conmunity about schiool-related matters & 29 & 55 & 103 & 73.37 & 1 & 2 & 10 & 7 & 8 \\
\hline Uses corriunity members to impruve the scliool environment & 24 & 56 & 102 & 72.86 & & 5 & 6 & 11 & 6 \\
\hline Arranges for in-service training for the faculty & 7 & 57 & 101 & 72.14 & 3 & & 8 & 11 & 6 \\
\hline
\end{tabular}


TABLE 21

\section{FUNCTIONAL AOMINISTRATIVE AGEAS RANKED ACCORDING TO THE MEAN BASED ON RESPONSES OF TEACHERS WITH 5-9 YEARS TEACHING EXPERIENCE}

\begin{tabular}{lcc}
\hline $\begin{array}{l}\text { Functional } \\
\text { Administrative } \\
\text { Area }\end{array}$ & $\begin{array}{l}\text { Rank } \\
\text { Order }\end{array}$ & $\begin{array}{c}\text { Mean } \\
\text { Weighted } \\
\text { Score }\end{array}$ \\
\hline Spiritual Climate & 1 & 124.58 \\
School Management & 2 & 118.00 \\
Staff-Principal Relations & 3 & 116.92 \\
Curriculum and Instruction & 4 & 110.58 \\
School-Community Relations & 5 & 110.42 \\
\hline
\end{tabular}

Table 22 presents raw scores, weighted scores based on responses of the teachers with ten or more years of teaching, and a rank order of the items in the second part of the questionnaire. The maximum possible score for an item is $5 \times 50=250$ : The column next to that for the weighted scores shows the obtained score as a percentage of the full total score for each item.

A mean for each area was computed from the weighted scores. Then the five areas were ranked according to their mean weighted scores. These data are shown in table 23. It should be noted that in all the previous rankings of the five areas as shown in tables 8 , $10,12,14,16,18$, and 20 , the area of spiritual climate was placed first and that of school-community relations last. In tabie 23, however, a different rank order is given. First in the ranking is 


\section{TABLE 22 (ALbrovidated)}

HERCEPIIONS OF IEACHERS (WITII 10 OR MOHE YEAIIS TEACHING EXPERIENCE OF PRIIICIPAL'S EFFECTIVEIIESS BY RANIKED ITEM

\begin{tabular}{|c|c|c|c|c|c|c|c|c|c|}
\hline \multirow{2}{*}{1 I E M } & \multirow{2}{*}{$\begin{array}{c}\text { Iteari } \\
\text { Number }\end{array}$} & \multirow{2}{*}{$\begin{array}{l}\text { Hank } \\
\text { Order }\end{array}$} & \multirow{2}{*}{$\begin{array}{l}\text { Weighted } \\
\text { Score }\end{array}$} & \multirow{2}{*}{$x$} & \multicolumn{5}{|c|}{ Raw Scores (50 Respondenls) } \\
\hline & & & & & so & Disagree & $\underset{3}{\text { Uncertain }}$ & $\underset{4}{\text { Agree }}$ & $\begin{array}{r}S A \\
5\end{array}$ \\
\hline \multicolumn{10}{|l|}{ The principal } \\
\hline Conducts himself/herseif wilh propriely at church metetings & 30 & 1 & 241 & 96.4 & & & & 9 & 41 \\
\hline Shows a positive attitude towards SDA doctrines & 35 & 1 & 241 & 96.4 & & & & 9 & 41 \\
\hline Promotes Christian education in the school & 5 & 3 & 236 & 94.4 & & & & 14 & 36 \\
\hline Provides for spiritual einphasis in the school & 15 & 4 & 234 & 93.6 & & & & 16 & 34 \\
\hline Is a reliable adtinistrator & 18 & 5 & 229 & 91.6 & & & 2 & 17 & 31 \\
\hline Underscands his/her duthuricy and responsiblitty & 43 & 6 & 228 & 91.2 & & & 2 & 18 & so \\
\hline Treats teachars as professionals & 16 & 6 & 228 & 91.2 & & 1 & 3 & 13 & 33 \\
\hline Involves students in religluus octivities & 10 & 8 & 227 & 90.8 & & & 3 & 17 & 30 \\
\hline Usas biblical principles in school leadershio & 40 & 9 & 220 & 90.4 & & & 3 & 18 & 29 \\
\hline Inviles suggestions froin ceachers regarding school rules & 48 & 10 & 225 & 90.0 & & & 2 & 21 & 27 \\
\hline Hakes decisions based on administrative knowledge & 8 & 11 & 224 & 89.6 & & 1 & 1 & 21 & 27 \\
\hline Hakes teachers foel worthy in thetr job & 36 & 12 & 221 & 68.1 & & 2 & 2 & 19 & 27 \\
\hline Is courteous and considerate with teachers & 31 & 13 & 220 & 88.0 & & & 4 & 22 & 24 \\
\hline Encourages Christian lifestyle amung students & 25 & 56 & 131 & 52.4 & & & & 19 & 31 \\
\hline Practlices his/her beliefs & 50 & 57 & 130 & 52.0 & & & 2 & 16 & 32 \\
\hline Shows a fritendly attitude toward tedchers & 51 & 58 & 128 & 51.2 & & & 1 & 20 & 29 \\
\hline Implatients the SDA philasoghy of education in the school & 60 & 58 & 128 & 51.2 & & & 2 & 13 & 34 \\
\hline llas a good sense of humiar & 26 & 00 & 127 & 50.8 & & & 2 & 19 & 29 \\
\hline
\end{tabular}


the area of school management. This is followed by the area of school-comunity relations. The area of spiritual climate is placed third, and that of curriculum and instruction fifth. Thus these most experienced teachers perceived the academy principal to be most effective in the area of school management, but least effective in the area of curriculum and instruction.

TABLE 23

FUNCTIONAL ADMINISTRATIVE AREAS RANKED ACCORDING TO THE MEAN BASED ON RESPONSES OF TEACHERS WITH TEN OR MORE YEARS TEACHING EXPERIENCE

\begin{tabular}{lcc}
\hline $\begin{array}{l}\text { Functional } \\
\text { Administrative } \\
\text { Areas }\end{array}$ & $\begin{array}{l}\text { Rank } \\
\text { Order }\end{array}$ & $\begin{array}{c}\text { Mean } \\
\text { Weighted } \\
\text { Score }\end{array}$ \\
\hline School Management & 1 & 216.67 \\
School-Commity Relations & 2 & 198.42 \\
Spiritual Climate & 3 & 196.42 \\
Staff-Principal Relations & 4 & 187.67 \\
Curriculum and Instruction & 5 & 185.83 \\
\hline
\end{tabular}

Table 24 presents raw scores, weighted scores based on responses of teachers with less than one year of teaching experience in the present school, and a rank order of the items in the second part of the questionnaire. The maximum possible score for an item is $5 \times 16=80$. The column next to that for the weighted scores shows the obtained score as a percentage of the full total score for each item.

A mean for each area was computed from the weighted scores 
IABLE 24 (Ablureviated)

PERCEPTIONS OF TEACHERS (WIIII LESS TIIAN ONE YLAR OF TEACHIHG IN PRESEHT SCHOOL)

OF PRIMCIPAL 'S FIFECTIVENESS BY RANKED ITEM

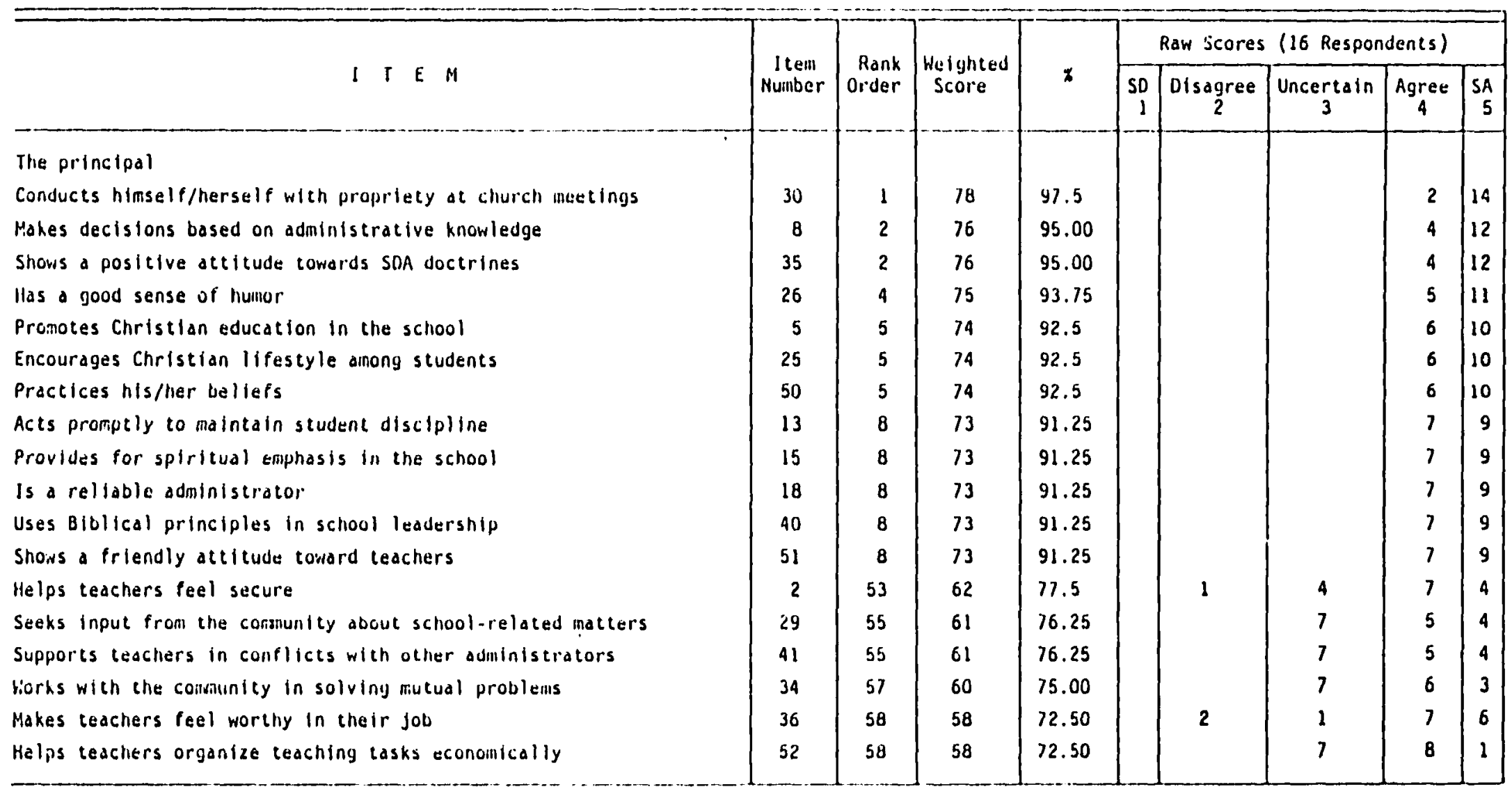


based on the responses of teachers with less than one year of teaching experience in the present school. Then the five areas were ranked according to their mean weighted scores. The maximum possible mean score for an area is $5 \times 16=80$. As shown in table 25, the area of spiritual climate was first and that of school management second. The area of school-community relations was placed fifth.

\section{TABLE 25}

FUNCTIONAL ADMINISTRATIVE AREAS RANKED ACCORDING

TO THE MEAN BASED ON RESPONSES OF TEACHERS

WITH LESS THAN ONE YEAR OF TEACHING

IN PRESENT SCHOOL

\begin{tabular}{lcc}
\hline $\begin{array}{l}\text { Functional } \\
\text { Administrative } \\
\text { Area }\end{array}$ & $\begin{array}{c}\text { Rank } \\
\text { Order }\end{array}$ & $\begin{array}{c}\text { Mean } \\
\text { 'Neighted } \\
\text { Score }\end{array}$ \\
\hline Spiritual Climate & 1 & 73.42 \\
School Management & 2 & 69.17 \\
Staff-principal Relations & 3 & 65.83 \\
Curriculum and Instruction & 4 & 64.75 \\
School-Community Relations & 5 & 63.75 \\
\hline
\end{tabular}

Table 26 presents raw scores, weighted scores based on responses of teachers with $1-4$ years of teaching experience in the present school, and a rank order of the items in the second part of the questionnaire. The maximum possible score for an item is $5 \times 59=295$. The column next to that for the weighted scores shows the obtained score as a percentage of the full total score for each item. 
IABLE 26 (Abbreviated)

PERCEPTIONS OF TEACHERS (HITII 1-4 YEARS OF TEACHING IN PRESENT SCHOOL)

\begin{tabular}{|c|c|c|c|c|c|c|c|c|c|}
\hline \multirow[b]{2}{*}{ I T E M } & \multirow[b]{2}{*}{$\begin{array}{l}\text { Iteull } \\
\text { Number }\end{array}$} & \multirow[b]{2}{*}{$\begin{array}{l}\text { Rank } \\
\text { Order }\end{array}$} & \multirow[b]{2}{*}{$\begin{array}{l}\text { We ighited } \\
\text { Score }\end{array}$} & \multirow[b]{2}{*}{$x$} & \multicolumn{5}{|c|}{ Raw Scores (59 Respondencs) } \\
\hline & & & & & $\begin{array}{r}\text { SD } \\
1\end{array}$ & Disagree & $\begin{array}{c}\text { Uncertain } \\
3\end{array}$ & $\underset{4}{\text { Agree }}$ & $\begin{array}{r}S A \\
5\end{array}$ \\
\hline \multicolumn{10}{|l|}{ The principal } \\
\hline Conducts himself/herse if with propriety at church metings & 30 & 1 & 278 & 94.24 & & & 3 & 11 & 45 \\
\hline Shows a positive attitude towards SDA doctrines & 35 & 2 & 216 & 93.56 & & & 1 & 17 & 41 \\
\hline Promotes Christian education in the scnool & 5 & 3 & 272 & 92.20 & & & 3 & 17 & 39 \\
\hline Provides for spiritual emphasis in the schuol & 15 & 4 & 270 & 91.53 & & 1 & 3 & 22 & 33 \\
\hline Implements the SOA philosophy of education in the school & 60 & 5 & 266 & 90.17 & & 1 & 4 & 18 & 36 \\
\hline Encourages Christian lifestyle among students & 25 & $\cdot 6$ & 265 & 89.83 & & & 4 & 22 & 33 \\
\hline Has a posilive altitude toward church leadership & 55 & 7 & 263 & 89.15 & & 1 & 5 & 19 & 34 \\
\hline Is sincere with the faculty & 1 & 8 & 262 & 88.81 & & 1 & 5 & 20 & 33 \\
\hline Practices his/her belfefs & so & 8 & 262 & 88.81 & & & 6 & 21 & 32 \\
\hline Encourages tedachers to discuss thetr problems with him/her & 46 & 30 & 223 & 75.59 & 1 & 6 & 14 & 22 & 16 \\
\hline Apprectates the problems of the community & 44 & 51 & 222 & 75.25 & 1 & 2 & 18 & 27 & 11 \\
\hline Helps teachers develop their own individuality & 56 & 52 & 221 & 74.92 & & 5 & 21 & 17 & 16 \\
\hline Seeks input frull parents regarding school tmprovement & 49 & 53 & 215 & 72.88 & & 3 & 24 & 23 & 9 \\
\hline Respects others' points of vlew & 21 & 54 & 213 & 12.20 & 2 & 1 & 10 & 24 & 22 \\
\hline Seeks input from the conmunity dbowt schual-related matters & 29 & 55 & 209 & $70.8 \mathrm{~s}$ & & 6 & 23 & 22 & 8 \\
\hline Uses cornitunlty menbers to himprove the school environment & 24 & 56 & 208 & $70.5:$ & & 7 & 19 & 23 & 9 \\
\hline Arranges for in-service training for the faculty & 7 & 57 & 202 & 68.47 & 2 & 5 & 21 & 23 & 7 \\
\hline Helps teachers accomplish their social netds & 11 & 58 & 190 & 64.41 & 1 & 12 & 20 & 20 & 5 \\
\hline
\end{tabular}


A mean weighted score for each area was computed from the weighted scores. Then the five areas were ranked according to their mean weighted scores. As shown in the rank order in table 27 , the area of spiritual climate was first. The area of school management was ranked second. The area that was placed fifth was that of schoolcommunity relations. Thus these teachers perceived the academy principal as most effective in the area of spiritual climate and least effective in the area of school-commity relations.

TABLE 27

FUNCTIONAL ADMINISTRATIVE AREAS RANKED ACCORDING

TO THE MEAN BASED ON RESPONSES OF TEACHERS

WITH 1-4 YEARS OF TEACHING

IN PRESENT SCHOOL

\begin{tabular}{lcc}
\hline $\begin{array}{l}\text { Functional } \\
\text { Adritinistrative } \\
\text { Area }\end{array}$ & $\begin{array}{c}\text { Rank } \\
\text { Order }\end{array}$ & $\begin{array}{c}\text { Mean } \\
\text { Neighted } \\
\text { Score }\end{array}$ \\
\hline Spiritual Climate & 1 & 262.17 \\
School Management & 2 & 242.67 \\
Staff-Principal Relations & 3 & 237.1 \\
Curriculum and Instruction & 4 & 227.8 \\
School-Commity Relations & 5 & 227.67 \\
\hline
\end{tabular}

Table 28 presents raw scores, weighted scores based on responses of teachers with 5-8 years of teaching experience in the present school, and a rank order of the items in the second part of the questionnaire. The maximum possible score for an item is $5 \times 20=100$. The column next to that for the weighted scores shows 
IABIE 2.8 (Abbrevialed)

PERCEPTIOHS OF IEACHERS (WIIII 5-8 YEAILS OF TIACIIIHG III PRESEIIT SCHOOL.

OF PRINCIPAL'S EFFECTIVENESS OY RAIKED ITEN

\begin{tabular}{|c|c|c|c|c|c|c|c|c|c|}
\hline \multirow[b]{2}{*}{ I I $\quad$ E $M$} & \multirow{2}{*}{$\begin{array}{l}\text { I teill } \\
\text { number }\end{array}$} & \multirow{2}{*}{$\begin{array}{r}\text { Rank } \\
\text { Order }\end{array}$} & \multirow[b]{2}{*}{$\begin{array}{l}\text { Heighted } \\
\text { Score }\end{array}$} & \multirow[b]{2}{*}{$x$} & \multicolumn{5}{|c|}{ Raw Scores (20 Respondents) } \\
\hline & & & & & $\begin{array}{c}S D \\
1\end{array}$ & $\begin{array}{c}\text { Disagree } \\
2\end{array}$ & $\underset{3}{\text { Uncertain }}$ & $\underset{4}{\text { Agree }}$ & $\begin{array}{r}5 i \\
5\end{array}$ \\
\hline The principal & & & & & & & & & \\
\hline Conducts hiriself/herself with propriety at church inetings & 30 & 1 & 97 & 97 & & & & 3 & 17 \\
\hline Shows a positive atticude towards SOA doctrines & 35 & 2 & 95 & 95 & & & 1 & 3 & 16 \\
\hline Is sincere with the faculty & 1 & 3 & 92 & 92 & & & & 8 & 12 \\
\hline Shows a frlendly attltude tuward teachers & 51 & 3 & 92 & 92 & & & & B & 12 \\
\hline Has a positive attitude towards church leadership & 55 & 3 & 92 & 92 & & & 2 & 4 & 14 \\
\hline Implenents the SDA philosophy of education in the school & 60 & 3 & 92 & 92 & & & 1 & 6 & 13 \\
\hline Promotes Christian education in the school & 5 & 7 & 91 & 91 & & & 2 & 5 & 13 \\
\hline Invites suggestlons from teachers rejarding school rules & 48 & 7 & 91 & 91 & & & 1 & 7 & 12 \\
\hline Practicas his/her bellefs & 50 & $y$ & 91 & 91 & & & 1 & 7 & 12 \\
\hline Responds to chang̣e & 38 & 49 & 80 & 80 & & 3 & & 11 & 6 \\
\hline Appreciates parents help in school activities & 39 & 51 & 78 & 38 & & & 1 & 8 & 5 \\
\hline Supports tedchers in conflicts with other administrators & 41 & 51 & 78 & 78 & & 2 & 4 & 8 & 6 \\
\hline Uses coryunity members to improve the school environiment & 24 & 53 & 76 & 76 & 1 & 2 & 4 & 6 & 7 \\
\hline Acts promptly to malntain student discipline & 13 & 34 & 74 & 74 & 1 & 4 & & 10 & 5 \\
\hline Seeks input from comununity dbout school-related malters & 29 & 54 & 74 & 74 & 1 & & 7 & 8 & 4 \\
\hline Steks input from parents regarding school improvement & 49 & 54. & 74 & 74 & & 3 & 6 & 5 & 6 \\
\hline Works with the cormunity in solving autual problelis & 34 & 57 & 71 & 71 & & 1 & 10 & 6 & 3 \\
\hline Melps teachers organize teaching tasks economically & 52 & 57 & 71 & 71 & & 3 & 6 & 8 & 3 \\
\hline
\end{tabular}




\begin{abstract}
the obtained score as a percentage of the full total score for each item.

A mean weighted score for each area was computed from the weighted scores based on tha responses of teachers with 5-8 years of teaching in the present school. Then the five areas were ranked according to their mean weighted scores. The maximum possible mean score for an area is $5 \times 20=100$. As shown in the rank order in table 29 , the areas of spiritual climate and staff-principal relations were ranked first and second. respectively. The area of curriculum and instruction was ranked fourth and that of school-community relations was placed last.
\end{abstract}

TABLE 29

FUNCTIONAL ADMINISTRATIVE AREAS RANKED ACCORDING

TO THE MEAN BASED ON RESPONSES OF TEACHERS

WITH 5-8 YEARS OF TEACHING

IN PRESENT SCHOOL

\begin{tabular}{lll}
\hline $\begin{array}{l}\text { Functional } \\
\text { Administrative } \\
\text { Area }\end{array}$ & $\begin{array}{l}\text { Rank } \\
\text { Order }\end{array}$ & $\begin{array}{c}\text { Mean } \\
\text { Neighted } \\
\text { Score }\end{array}$ \\
\hline Spiritual Climate & 1 & 89.5 \\
Staff-Principal Relations & 2 & 83.75 \\
School Management & 3 & 83.42 \\
Curriculum and Instruction & 4 & 81.67 \\
School-Community Reiations & 5 & 79.5 \\
\hline
\end{tabular}

Table 30 presents raw scores, weighted scores based on responses of teachers with over eight years of teaching in the 
TABIE 30 (Abbreviation)

PERCEPTIONS OF IEACIIERS (HITH OVER 8 YEARS OF IEACHIMG IN PRESENT SCHOOL) OF PRIIICIPAL'S EFFECTIVENESS BY RAIIKED ITEM

\begin{tabular}{|c|c|c|c|c|c|c|c|c|c|}
\hline \multirow[b]{2}{*}{$\perp \quad T E M$} & \multirow{2}{*}{$\begin{array}{c}\text { ltem } \\
\text { Number }\end{array}$} & \multirow{2}{*}{$\begin{array}{r}\text { Rank } \\
\text { Order }\end{array}$} & \multirow{2}{*}{$\begin{array}{c}\text { We fighted } \\
\text { Score }\end{array}$} & \multirow[b]{2}{*}{$x$} & \multicolumn{5}{|c|}{ Raw Scores (19 Respondents) } \\
\hline & & & & & $\begin{array}{r}\text { SO } \\
1\end{array}$ & $\underset{2}{\text { Disagree }}$ & $\begin{array}{c}\text { Uncertain } \\
3\end{array}$ & $\begin{array}{c}\text { Agree } \\
4\end{array}$ & $\begin{array}{r}S A \\
5\end{array}$ \\
\hline \multicolumn{10}{|l|}{ The principal } \\
\hline Provides for spiritual emphasis in the school & 15 & 1 & 92 & 95.84 & & & & 3 & 16 \\
\hline Promotes Christian education in the school & 5 & 2 & 91 & 95.78 & & & & 4 & 15 \\
\hline Shows a positive attitude towards SOA doctrines & 35 & 2 & 91 & 95.78 & & & & 4 & 15 \\
\hline Is sincere with the foculty & 1 & 4 & 90 & 94.74 & & & & 5 & 14 \\
\hline Encourages Christian Ilfestyle amang studencs & 25 & 5 & 89 & 93.68 & & & & 6 & 13 \\
\hline Understands his/her authority and responsibility & 13 & 5 & 89 & 93.68 & & & & 6 & 13 \\
\hline Has a positive attitude tcivard church leadership & 55 & 5 & 89 & 93.68 & & & & 6 & 13 \\
\hline Involves students in religious activities & 10 & 8 & 88 & 92.63 & & & 1 & 5 & 13 \\
\hline Treates teachers as professlonals & 16 & 8 & 88 & 92.63 & & & 2 & 3 & 14 \\
\hline Has a good sense of hulior & 26 & 8 & 88 & 92.63 & & & & 7 & 12 \\
\hline Creates a friendly interaction between the scliool and the comnunity & 19 & 53 & 72 & 75.79 & & & 4 & 10 & 4 \\
\hline Conducts hinself/herself with proprtety at church meetings & 30 & 54 & 71 & 74.74 & & & & 4 & 15 \\
\hline Uses community members to inpiove the school environment & 24 & 55 & 70 & 73.68 & & 1 & 5 & 12 & 1 \\
\hline Seas himself/herself mainly os a facilltator of the educational process & 57 & 55 & 70 & 73.68 & 1 & & 5 & 6 & 6 \\
\hline Arranges for in-service training for the faculty & 7 & 57 & 66 & 69.47 & 1 & 2 & 5 & 9 & 2 \\
\hline Helps teachers organize teaching tasks economically & 52 & 58 & 65 & 68.42 & & 2 & 8 & 8 & 1 \\
\hline Helps teachers accomplish their social needs & 11 & 59 & 64 & 01.37 & & 2 & 9 & 7 & 1 \\
\hline
\end{tabular}


present school, and a rank order of the items in the second part of the questionnaire. The maximum possible score for an item is $5 \times 19=95$. The column next to that for the weighted scores shows the obtained score as a percentage of the full total score for each item.

A mean for each area was computed from the weighted scores based on the responses of teachers with more than eight years of teaching in the present school. Then the five areas were ranked according to their mean weighted scores. The maximum possible mean score for an area is $5 \times 19=95$. As shown in the rank order in table 31 , the area of spiritual climate was ranked first and that of staff-principal relations second. The area of school-comunity relations was placed last. The rank order indicates that the teachers perceived the academy principal to be most effective in the area of spiritual climate and least effective in the area of school-community relations.

The rank order of the functional areas suggests that the perceptions of these teachers regarding the effectiveness of the principal in the present school were in accord with those of the teachers who had taught for 5-8 years in the present school. However, according to the responses of teachers with 1-4 years of teaching in the present school, the area of school management was ranked second and the area of staff-principal relations was ranked third. There was no difference in the rank order of the other areas for the teachers teaching in the present school. 
TABLE 31

FUINCTIONAL ADMINISTRATIVE AREAS RANKED ACCORDING

TO THE MEAN BASED ON RESPONSES OF TEACHERS

WITH OVER 8 YEARS OF TEACHING

IN PRESENT SCHOOL

\begin{tabular}{lcc}
\hline $\begin{array}{l}\text { Functional } \\
\text { Administrative } \\
\text { Area }\end{array}$ & $\begin{array}{c}\text { Rank } \\
\text { Order }\end{array}$ & $\begin{array}{c}\text { Mean } \\
\text { Weighted } \\
\text { Score }\end{array}$ \\
\hline Spiritual Climate & 1 & 86.83 \\
Staff-Principal Relations & 2 & 82.58 \\
School Management & 3 & 82.33 \\
Curriculum and Instruction & 4 & 77.58 \\
School-Community Relations & 5 & 75.42 \\
\hline
\end{tabular}

\section{Comparison of Perceptions of the Various Teacher Categories}

The descriptive analysis of data according to the categories of teachers has presented the perceptions of teachers by ranked items. An examination of the tables shows that in general the items that appeared most frequently in the top ten places of the rank order belonged to the area of spiritual climate. The items that appeared most often in the bottom ten places of the rank order belonged to the area of school-community relations. The rank order of the areas using the mean weighted scores of the male teachers was the same as that for the female teachers. They strongly agreed that the princidal was most effective in the area of spiritual climate and more effective in that of school management. The area of staff-principal relations was ranked third. The area of curriculum and instruction and that of 
school-comunity relations were placed fourth and fifth, respectively. The descriptive analysis then shows that the perceptions of the male teachers concerning the effectiveness of an academy principal did not differ from those of the female teachers.

The same rank order of the areas by mean weighted scores was also noted when the perceptions of the following categories were analyzed: teachers with master's degrees, teachers with other levels of education, teachers with 1-4 years of teaching experience in general, and those with four or fewer years of teaching in the present school.

However, the more experienced the teachers became, the more their perceptions of the principal's effectiveness differed. For example, teachers with ten or more years of teaching felt that the principal was very effective in the area of school management and effective in school-community relations. According to the perceptions of these teachers, the area of spiritual climate was ranked third, that of staff-principal relations fourth, and curriculum and instruction last.

Teachers with five or more years of teaching in the present school agreed with most of the other categories that the principal was very effective in the area of spiritual climate. However, this group of teachers felt that the next area in which the principal was effective was that of staff-principal relations, followed by curriculum and instruction. These teachers perceived the principal's effectiveness to be least strong in the area of school-community relations. 
The analysis of the demographic data, describing the teachers' sample, has been presented to help the reader have a better understanding of the responses of the teachers concerning the teachers' perceptions of the principal's effectiveness. The next section of this chapter presents the analysis of data on the five functional areas of administration.

\section{Hypothes is Testing}

To guide the analysis of the data, four specific hypotheses in the null form were developed. This section of the chapter presents the results of testing the hypotheses.

Hypothesis 1. There is no significant difference in teachers" perceptions of principal's effectiveness between those principals ranked 1-5 (Group 1) and those ranked 6-10 (Group 2).

This hypothesis was tested separately for each of the five areas of administration, namely, staff-principal relations (area 1), curriculum and instruction (area 2), school manageinent (area 3), school-commity relations (area 4), and spiritual climate (area 5). Hence there were five sub-hypotheses, one on each functional area of administration. Each of these sub-hypotheses was tested by the t-test for independent means. Table 32 presents the results of the $t$ tests. The means in each case are based on the responses of 53 teachers with respect to principais in Group 1 and 62 teachers with respect to principals in Group 2.

For each of the five areas, the table shows not only the $t$ values, but also the probability for significance, and means for 
Groups 1 and 2. A comparison of the means indicates that Group 1 has higher means than Group 2 for each of the five areas. However, only two of the five areas have significant results at the .05 level. These two areas are curriculum and instruction and spiritual climate. These are marked with an asterisk in the table 32 . Hence. the null hypotheses $1 b$ and le are rejected while the null hypotheses la, lc, and $1 d$ are retained. These three hypotheses concern the areas of staff-principal relations, school management, and school-community relations, respectively.

TABLE 32

HYPOTHESIS 1. T-TEST ON ALL AREAS

\begin{tabular}{|c|c|c|c|c|c|c|}
\hline \multirow{2}{*}{ Hypothesis } & \multirow{2}{*}{ Area } & \multicolumn{2}{|c|}{ Me a n } & \multirow{2}{*}{$t$} & \multirow{2}{*}{$p$} & \multirow{2}{*}{$\begin{array}{c}\text { Significant } \\
\text { at } .05\end{array}$} \\
\hline & & Group 1 & Group 2 & & & \\
\hline la & 1 & 50.9811 & 48.8548 & 1.69 & .094 & ns \\
\hline $1 b$ & 2 & 48.7547 & 45.5161 & $\star 2.27$ & .025 & 5 \\
\hline Ic & 3 & 51.2641 & 48.9484 & 1.83 & .07 & ns \\
\hline Id & 4 & 48.3207 & 45.9839 & 1.96 & .052 & ns \\
\hline le & 5 & 55.0566 & 51.8064 & $* 2.32$ & .022 & $s$ \\
\hline
\end{tabular}

Hypothesis 2. There is no significant difference in teachers' perceptions of principal's effectiveness among the five functional areas for both groups.

Table 33 gives the means and standard deviations on all five areas. 
TABLE 33

MEANS AND STANDARD DEVIATIONS

FIVE AREAS - ALL RESPONDENTS

\begin{tabular}{l|r|r|r|r|r}
\hline & \multicolumn{4}{|c}{ Five Functional Areas } \\
\cline { 2 - 6 } & $\begin{array}{c}1 \\
\text { Staff- } \\
\text { Principal }\end{array}$ & $\begin{array}{c}\text { Curric. } \\
\text { Instr. }\end{array}$ & $\begin{array}{c}\text { School } \\
\text { Manag. }\end{array}$ & $\begin{array}{c}\text { School } \\
\text { Comm. }\end{array}$ & $\begin{array}{c}5 \\
\text { Spiritual } \\
\text { Climate }\end{array}$ \\
\hline Means & 49.83478 & 47.00870 & 49.06087 & 47.06087 & 53.30435 \\
Standard Deviations & 6.93318 & 8.01807 & 9.72005 & 6.44584 & 7.79245 \\
\hline
\end{tabular}

To test the null hypothesis that these means are not significantly different, one-way analysis of variance for repeated measures was used. Table 34 shows the analysis of variance.

TABLE 34

ANALYSIS OF VARIANCE - HYPOTHESIS 2

\begin{tabular}{l|c|c|c|c|c}
\hline $\begin{array}{c}\text { Source of } \\
\text { Variation }\end{array}$ & $\begin{array}{c}\text { Sum of } \\
\text { Squares }\end{array}$ & $\begin{array}{c}\text { Degrees of } \\
\text { Freedom }\end{array}$ & $\begin{array}{c}\text { Mean } \\
\text { Square }\end{array}$ & $\begin{array}{c}\text { Calculated } \\
\text { F-Ratio }\end{array}$ & $\begin{array}{c}\text { Probability } \\
\text { of } F\end{array}$ \\
\hline $\begin{array}{l}\text { Between } \\
\text { areas }\end{array}$ & 3062.01739 & 4 & 765.50435 & 34.36 & $<.00005$ \\
$\begin{array}{l}\text { Error } \\
\text { Srrot }\end{array}$ & 10157.98261 & 456 & 22.27628 & & \\
\hline
\end{tabular}

The F-ratio of 34.36 , with $p<.00005$, indicates that there is a significant difference among the means. The null hypothesis is, therefore, rejected. To study the differences between all possible pairs of means, the Newman Keuls procedure was used. Table 35 shows 
TABLE 35

TABLE OF CONTRASTS BETWEEN MEANS HYPOTHESIS 2

\begin{tabular}{|c|c|c|c|c|c|}
\hline \multirow{3}{*}{$\begin{array}{l}\text { Means on } \\
\text { Areas }\end{array}$} & \multicolumn{5}{|c|}{ Means on Areas } \\
\hline & $\overline{x_{2}}$ & $\overline{\bar{x}_{4}}$ & $\overline{\bar{x}_{3}}$ & $\bar{x}_{1}$ & $\overline{\bar{x}_{5}}$ \\
\hline & 47.009 & 47.061 & 49.530 & 49.835 & 53.304 \\
\hline $\bar{x}_{2}$ & --- & 0.052 & $2.521 *$ & $2.826^{\star}$ & $6.295 *$ \\
\hline $\bar{x}_{4}$ & & $\ldots$ & $2.469 \star$ & $2.774^{\star}$ & $6.243 *$ \\
\hline $\bar{x}_{3}$ & & & $-\cdots$ & 0.305 & 3.774 * \\
\hline $\bar{x}_{1}$ & & & & --- & $3.469 *$ \\
\hline
\end{tabular}

the contrasts between the means

The statistically significant differences are marked with an asterisk. The table shows that the pairs of means on areas 4 (schoor community relations) and 2 (curriculum and instruction), and on 3 (school management) and 1 (staff-principal relations) are not significantly different. All the other pairs are. The mean on area 5 (spiritual climate) is significantly higher than all the others. The means on areas 1 (staff-principal relations) and 3 (school management) are each significantly higher then the means on areas? (curriculum and instruction) and 4 (school-community relations).

Hypothesis 3. There is no significant differnece in teachers' perceptions of principal's effectiveness among the five functional areas for principals ranked 1-5 (Group 1). 
This hypothesis was tested by one-way analysis of variance

for repeated measures.

Table 36 gives the means and standard deviations on all five functional areas of administration for the teachers who responded in respect of Group 1 principais.

\section{TABLE 36}

\section{MEANS AND STANDARD DEVIATIONS FIVE AREAS- GROUP I PRINCIPALS}

\begin{tabular}{l|r|r|r|r|r}
\hline & \multicolumn{5}{|c}{ Five Functional Areas } \\
\cline { 2 - 6 } & $\begin{array}{c}1 \\
\text { Staff- }\end{array}$ & $\begin{array}{c}2 \\
\text { Curric. \& } \\
\text { Instr. }\end{array}$ & $\begin{array}{c}\text { School } \\
\text { Manag. }\end{array}$ & $\begin{array}{c}\text { School } \\
\text { Comm. }\end{array}$ & $\begin{array}{c}5 \\
\text { Spiritual } \\
\text { Climate }\end{array}$ \\
\hline Cell Means & 50.98113 & 48.75472 & 51.26415 & 48.32075 & 55.05660 \\
Standard Deviations & 5.75624 & 5.80088 & 7.12836 & 6.21033 & 5.23088 \\
\hline
\end{tabular}

To test the nuli hypothesis that these means are not significantly different, one-way anaiysis of variance for repeated measures was used. Table 37 shows the analysis of variance.

The F-ratio of 36.92 , with $p<.00005$, indicates that there is a significant difference among the means. The null hypothesis is, therefore, rejected.

To study the differences between all possible pairs of means, the Newman-Keuls procedure was used. Table 38 shows the contrasts between the means. 
TABLE 37

ANALYSIS OF VARIANCE - HYPOTHES IS 3

\begin{tabular}{l|c|c|c|c|c}
\hline $\begin{array}{c}\text { Source of } \\
\text { Variation }\end{array}$ & $\begin{array}{c}\text { Sum of } \\
\text { Squares }\end{array}$ & $\begin{array}{c}\text { Degrees of } \\
\text { Freedom }\end{array}$ & $\begin{array}{c}\text { Mean } \\
\text { Square }\end{array}$ & $\begin{array}{c}\text { Calculated } \\
\text { F-Ratio }\end{array}$ & $\begin{array}{c}\text { Probability } \\
\text { of F }\end{array}$ \\
\hline $\begin{array}{c}\text { Between } \\
\text { areas }\end{array}$ & 1519.41887 & 4 & 379.85472 & $36.92^{\star}$ & $<.00005$ \\
Error & 2140.18113 & 208 & 10.28933 & & \\
\hline
\end{tabular}

TABLE 38

TABLE OF CONTRASTS BETWEEN MEANS

HYPOTHESIS 3

\begin{tabular}{|c|c|c|c|c|c|}
\hline \multirow{3}{*}{$\begin{array}{c}\text { Means on } \\
\text { Areas }\end{array}$} & \multicolumn{5}{|c|}{ Means on Areas } \\
\hline & $\overline{\bar{X}_{4}}$ & $\overline{\bar{x}_{2}}$ & $\overline{\bar{x}_{1}}$ & $\bar{x}_{3}$ & $\overline{\gamma_{5}}$ \\
\hline & 48.321 & 48.755 & 50.981 & 51.264 & 55.057 \\
\hline $\bar{x}_{4}$ & --- & 0.434 & $2.660^{*}$ & $2.943^{*}$ & $6.736^{\star}$ \\
\hline $\bar{x}_{2}$ & & $-\cdots$ & $2.226 *$ & $2.509 *$ & $6.302 \star$ \\
\hline $\bar{x}_{1}$ & & & --- & 0.283 & $4.076^{\star}$ \\
\hline $\bar{x}_{3}$ & & & & $-\cdots$ & $3.793 *$ \\
\hline
\end{tabular}

The statistically significant differences are marked with an asterisk. The table shows that the pairs of means on areas 4 (schoolcommunity relations) and 2 (curriculum and instruction), and on 1 (staffprincipal relations) and 3 (school management) are not significantly different. All the other pairs are. The mean on area 5 (spiritual 
climate) is significantly higher than all the others. The means on areas 1 (staff-principal relations) and 3 (school management) are each significantly higher than the means on areas 2 (curriculum and instruction) and 4 (school-community relations).

Hypothesis 4. There is no significant difference in teachers" perceptions of principal's effectiveness among the five functional areas for principals ranked 6-10 (Group 2).

This hypothesis was tested by one-way analysis of variance for repeated measures.

Table 39 gives the means and standard deviations on all five functional areas of administration for the teachers who responded in respect of Group 2 principals.

TABLE 39

MEANS AND STANDARD DEVIATIONS FIVE AREAS GROUP 2 PRINCIPALS

\begin{tabular}{l|r|r|r|r|r}
\hline & \multicolumn{5}{|c}{ Five Functional Areas } \\
\cline { 2 - 6 } & $\begin{array}{c}\text { Staff- } \\
\text { Principal }\end{array}$ & $\begin{array}{c}2 \\
\text { Curric.\& } \\
\text { Instr. }\end{array}$ & $\begin{array}{c}\text { School } \\
\text { Manag. }\end{array}$ & $\begin{array}{c}\text { School } \\
\text { Comm. }\end{array}$ & $\begin{array}{c}\text { Spiritual } \\
\text { Climate }\end{array}$ \\
\hline Cel1 Means & 48.85484 & 45.51613 & 45.04839 & 45.98387 & 51.80645 \\
Standard Deviations & 7.71170 & 9.30317 & 11.33170 & 6.49714 & 9.23081. \\
\hline
\end{tabular}

To test the null hypothesis that these means are not significantly different, one-way analys is of variance for repeated measures vas used. Table 40 shows the analysis of variance. 
TABLE 40

ANALYSIS OF VARIANCE - HYPOTHESIS 4

\begin{tabular}{l|c|c|c|c|c}
\hline $\begin{array}{c}\text { Source of } \\
\text { Variation }\end{array}$ & $\begin{array}{c}\text { Sum of } \\
\text { Squares }\end{array}$ & $\begin{array}{c}\text { Degrees of } \\
\text { Freedom }\end{array}$ & $\begin{array}{c}\text { Mean } \\
\text { Square }\end{array}$ & $\begin{array}{c}\text { Calculated } \\
\text { F-Ratio }\end{array}$ & $\begin{array}{c}\text { Probability } \\
\text { of F }\end{array}$ \\
\hline $\begin{array}{c}\text { Between } \\
\text { arezs }\end{array}$ & 1577.76129 & 4 & 394.44032 & $12.06^{\star}$ & $<.00005$ \\
Error & 7982.63871 & 244 & 32.71573 & & \\
\hline
\end{tabular}

The F-ratio of 12.06 , with $p<.0005$, indicates that there is a significant difference among the means. The null hypothesis is, therefore, rejected.

io study the differences between all possible pairs of means, the Newman-Keuls procedure was used. Table 41 shows the contrasts between the means.

The statisticaliy significant differences are marked with an asterisk. The table shows that the pairs of means on areas 4 (schoolcommunity relations) and 2 (curriculum and instruction), and on 1 (staffprincipal relations) and 2 (school management) are not significantly different. All the other pairs are. The mean on area 5 (spiritual climate) is significantly higher than all the others. The means on areas 1 (staff-principal relations) and 3 (school management) are each significantly higher than the means on areas 2 (curriculum and instruction) and 4 (school-community relations). 
TABLE 41

TABLE OF CONTRASTS BETWEEN MEANS

HYPOTHESIS 4

\begin{tabular}{c|c|c|c|c|c}
\hline \multirow{2}{*}{$\begin{array}{l}\text { Means of } \\
\text { Variation }\end{array}$} & \multicolumn{5}{|c}{ Means on Areas } \\
\cline { 2 - 6 } & $\bar{x}_{2}$ & $\bar{x}_{4}$ & $\bar{x}_{3}$ & $\bar{x}_{1}$ & $\bar{x}_{5}$ \\
\cline { 2 - 6 } & 45.516 & 45.984 & 48.048 & 48.655 & 51.806 \\
\hline $\bar{x}_{2}$ & $\ldots-$ & 0.468 & $2.532^{\star}$ & $3.339^{\star}$ & $6.290^{\star}$ \\
$\bar{x}_{4}$ & &.-- & $2.064^{\star}$ & $2.871^{\star}$ & $5.822^{\star}$ \\
$\bar{x}_{3}$ & & & $-\ldots .807$ & $3.758^{\star}$ \\
$\bar{x}_{1}$ & & & & $-\cdots$ & $2.951^{\star}$ \\
\hline
\end{tabular}

Summary

This chapter has presented an analysis of data collected by a two-part questionnaire on the perceptions of classroom teachers concerning the Seventh-day Adventist academy principal's effectiveness in the Lake Union Conference in carrying out five functional areas of administration, namely, staff-principal relations, curriculum and instruction, school management, school-community relations, and spiritual climate.

The chapter then outlined demographic descriotions of the sample and gave information on the reliability of the five sub-scales of the instrument. It also presented basic data from the sub-scales of the instrument for all sub-groups. Finaliy the chapter provided analyses to test the hypotheses.

The null hypothesis (Hyp. I) that there was no significant 
difference in teachers' perceptions of principal's effectiveness between thuse principals ranked 1-5 (Group 1) and those ranked 6-10 (Group 2) was accepted, except for the functional-administrative areas 2 (curriculum and instruction) and 5 (spiritual climate). The null hypothesis (Hyp. 2) that there was no significant difference in teachers' perceptions of principal's effectiveness among the five functional areas for both groups was rejected. Further analysis indicated that the mean on area 5 (spiritual climate) was significantly higher than all the others. The means on areas 1 (staff-principal relations) and 3 (school management) were each significantly higher than the means on areas 2 (curriculum and instruction) and 4 (school-community relations). All other differences were not significant.

The null hypothesis (Hyp. 3) that there was no significant difference in teachers' perceptions of principal's effectiveness among the five functional areas for principals ranked 1-5 (Group 1) was rejected. The mean on area 5 (spiritual climate) was significantly higher than all the others. The means on areas 1 (staff orincipal relations) and 3 (school management) were each significantly higher than the means on areas 2 (curriculum and instruction) and 4 (school-community relations L. All other differences were nnt. significant.

The null hypothesis (Hyp. 4) that there was no significant difference in teachers' perceptions of principal's effectiveness among the five functional areas for principals ranked 6-10 (Group 2) was rejected. Further analys is showed that the mean on area 5 
(spiritual climate) was significantiy nigher than all the others. ine means on areas 1 (staff-principal relations) and 3 (school management) were each significantly higher than the means on areas 2 (curriculum and instruction) and 4 (schooi-community relations). All other differences were not significant.

For all three groups the significant contrasts between means were the same: the mean on area 5 was higher than all the others. The means on areas 1 and 3 were each higher than those on areas 2 and 4.

The next chapter summarizes the study and presents conclusions derived from the analysis and evaluation of the data. The chapter also includes implications and recommendations for further study. 
CHAPTER $V$

SUMMARY, CONCLUSIONS, AND RECOMMENDATIONS

This chapter is divided into three parts. The first part is a summary of the whole study presenting the purpose, methodology, and findings; the second part presents a discussion of the findings; and the third part presents recommendations to the Lake Union Conference and for further research.

Surmary

The purpose of this study was to identify the perceptions of classroom teachers concerning the Seventh-day Adventist academy principals' effectiveness in the Lake Union Conference in carrying out five functional-administrative areas. These five areas are staff-orincipal relations, curriculum and instruction, school management, school-community relations, and spiritual climate.

\section{Methodology}

In the Lake Union Conference, there are five local conferences, each with at least one academy. There are ten academies altogether. Four hypotheses were developed to direct the study.

Sample

There were 137 academy teachers in the whole of the Lake Union Conference in 1982-83. They were all requested to respond 
to the questionnaire that was sent to them.

Questionnaire

A two-part questionnaire used to cather data for the study was a modified form of the one originally designed by José A. Acosta-Ramos in 1978 at Lehigh University. In addition to the four functional areas of administration which Acosta-Ramos identified, a fifth area, called spiritual climate, was included for teachers to express their perceptions of a principal's effectiveness with regard to the spiritual aspect of his leadership in a Seventh-day Adventist academy.

Collection of Data

On October 19, 1982, the researcher obtained permission from the Director of Education in the Lake Union Conference to collect data from the ten academies.

Of the 137 copies of the questionnaire which were sent out to teachers, 115 (or 84\% approximately) were returned in usable form by January $16,1983$.

Only the second part of the questionnaire was sent to both the teachers and the superintendents of schools. All the copies of the questionnaire were received from the superintendents by February $15,1983$.

Analysis of Data

The data were analyzed in two ways: (1) by description and (2) by testing the hypotheses. Teachers' perceptions 
were examined by ranking the questionnaire statements according to their weighted scores in the different categories. On the basis of the ranked statements, the five functional areas of administration were also ranked for each category to discover how effectively the academy principal performed in the school.

To test the hypotheses, independent $t$-tests and analysis of variance for repeated measures were used.

\section{Findings}

A descriptive analysis of the data was undertaken for each of the following categories of respondents:

a. All the teachers.

b. All the male teachers.

c. All the female teachers.

d. Teachers with master's degrees.

e. Teachers with other levels of education.

$\therefore$ Teachers with 1-4 years of teaching experience.

g. Teachers with 5-9 years of teaching experience.

h. Teachers with ten or more years of teaching experience.

i. Teachers with less than one year of teaching experience in the present school.

$j$. Teachers with 1-4 years of teaching experience in the present school.

k. Teachers with 5-8 years of teaching experience in the present school.

1. Teachers with more than eight years of teaching experience in the present school. 
For each category, weighted scores and a rank order were computed by using the responses of the members composing the category. Questionnaire statements for each of the five functional areas of administration were identified. Total weighted scores and mean weighted scores were computed. On the basis of these mean weighted scores, the five functional areas were ranked for each category of teachers.

With the exception of categories $(h),(k)$, and (1), the rank order of the areas in each category was as follows:

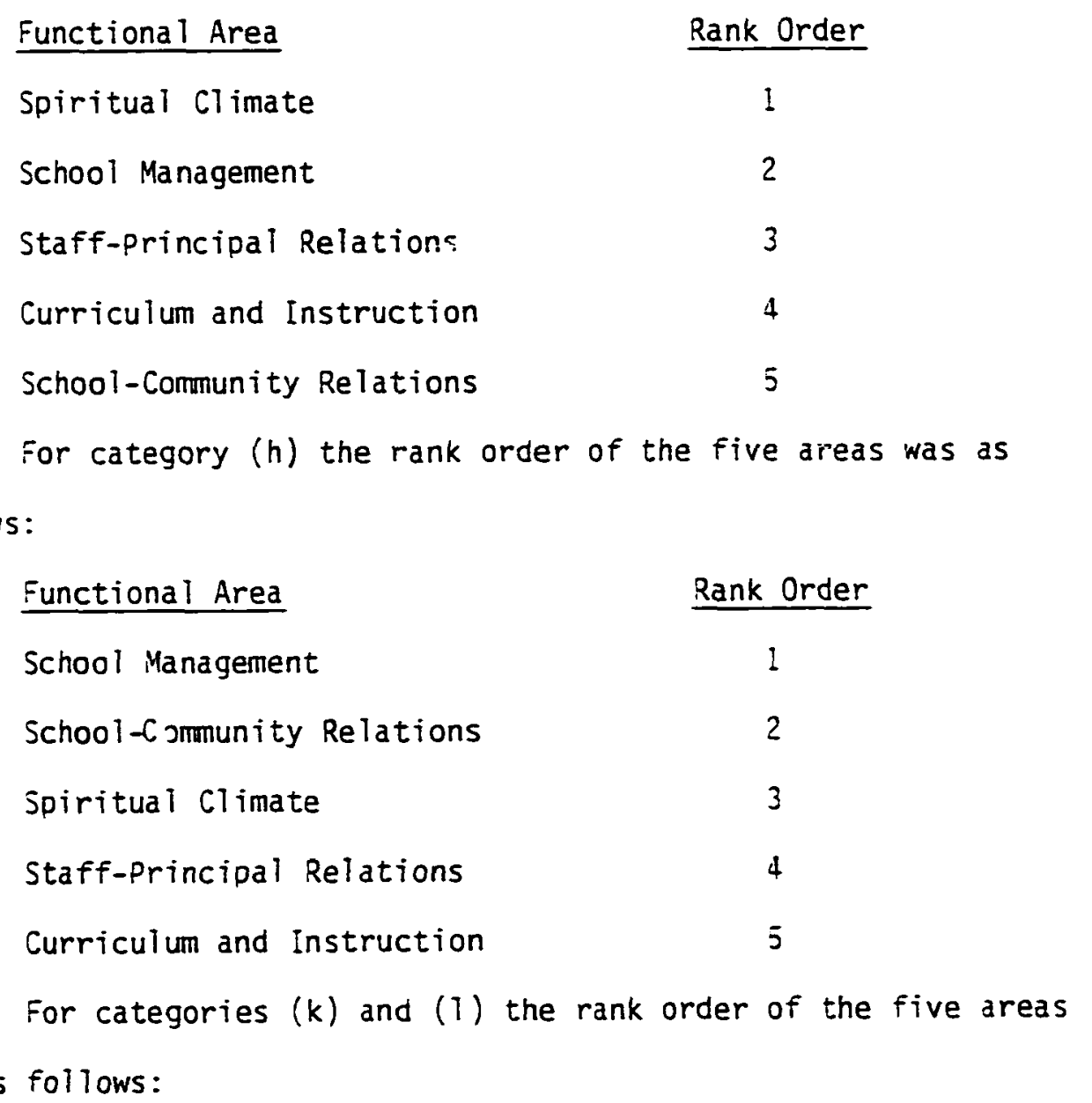


Functional Area

Soiritual $\mathrm{Cl}$ imate

Staff-Principal Relations

School Management

Curriculum and Instruction

School-Community Relations
Rank Order

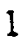

2

3

4

5

In general, the items that appeared most frequently in the top ten places of the rank order belonged to the area of spiritual climate. The items that appeared most often in the botton ten places of the rank order belonged to the area of school-community relations.

In addition to the descriptive analysis, four hypotheses which had been developed in the null form were tested for statistical significance.

Hypothesis 1. There is no significant difference in teachers' perceptions of principal's effectiveness between those principals ranked 1-5 (Group 1) and those ranked 6-10 (Group 2).

This hypothesis was tested separately for each of the five areas of administration. Hence there were five sub-hypotheses, one on each functional area of administration. Each of these sub-hypotheses was tested by t-tests for independent means.

A comparison of the means indicated that Group I had higher means than Group 2 for each of the five areas. However, only two of the five areas had significant results at the .05 level. These two areas were curriculum and intruction, and spiritual climate.

Hypothesis 2. There is no significant difference in teachers' 
perceptions of principal's effectiveness among the five functional

areas for both groups.

Means and standard deviations were computed on all five func-

tional areas of administration for the total group of respondents.

One-way analysis of variance for repeated measures was used.

The results showed that there was a significant difference among the

means. The null hypothesis was, therefore, rejected.

A Newman-Keuls procedure indicated that the mean on the area of spiritual climate was significantly higher than all the others. The means on the areas of staff-principal relations and school management were each significantly different from the means on the areas of curriculum and instruction and school-community relations.

Hypothesis 3. There is no significant difference in teachers' perceptions of principal's effectiveness among the five functional areas for principals ranked 1-5 (Group 1).

Heans and standard deviations were computed on all five functional areas of administration. One-way analysis of variance for repeated measures was used. The results showed that there was a significant difference among the means. The null hypothesis was, therefore, rejected.

A Newman-Keuls procedure indicated that the mean on the area of spiritual climate was significantly higher than all the others. The means on the areas of staff-principal relations and school management were each significantly different from the means on the areas of curriculum and instruction and school-commity relations.

Hypothesis 4. There is no significant difference in teachers' 
perceptions of principal's effectiveness among the five functional areas for principals ranked 6-10 (Group 2).

Means and standard deviations were computed on all five functional areas of administration. One-way analysis of variance for repeated measures was used. The results showed that there was a significant difference among the means. The null hypothesis was, therefore, rejected.

A Newman-Keuls procedure indicated that the mean on the area of spiritual climate was significantly higher than all the others. The means on the areas of staff-principal relations and school management wire each significantly different from the means on the areas of curriculum and instruction and school-commity relations.

\section{Conclusions}

The studies which were reviewed suggest that the perceptions of a principal's effectiveness by the different constituencies, especially the teachers, influence the principal's role. Teachers' perceptions of the principal's behavior can provide feedback for the principal to direct his efforts toward achieving desired changes in his/her behavior. The principal must be aware of the consistency of his/her behavior patterns and his/her influence on other persons, especially teachers, students, and parents.

The findings suggested the following conclusions:

1. The descriptive analys is of the data showed that there was a high degree of consistency in teachers' perceptions of the orincipal's effectiveness in the five functional areas of 
administration. The testing of the four hypotheses also confirmed differences in the way the various categories of teachers perceived the effectiveness of the principal in the specified areas of administration.

2. The overall results of the study show that many classroom teachers in SDA academies in the Lake Union Conference strongly agreed that the principal was effective in the area of spiritual climate. They agreed that the principal was a practicing Christian who showed a positive attitude toward the tenets of the SOA Church. The principal promoted a spiritual climate by ifuplementing the SDA philosophy of education and objectives in running the school and by providing opportunities for students to be involved in religious activities.

3. Most of the teachers also agreed that the principal was effective in the area of school management. He/she was a fair and reliable leader who made decisions which reflected administrative knowledge. Agreement was weak, however, on the principal's ability to encourage staff members to make suggestions regarding school rules and regulations or to utilize the staff's skilis at a maximum.

4. Teachers' responses showed that the principal's effectiveness was less strong in the area of staff-principal relations. The principal could be more effective in this area by relating well to the faculty, making them feel worthy in their job, helping each member to develop his/her own individuality and thus accomolish his/her social needs.

5. The principal's effectiveness was relatively weak in the area of curricuium and instruction. The principal could enhance 
his/her effectiveness by being more familiar with the instructional problems of the teachers and by arranging in-service training, taking into account the professional needs of his/her faculty, thus stimulating teachers' initiative and creativeness.

6. The principal's effectiveness was perceived weakest in the area of school-comunity relations. The teachers felt that the principal could do more by encouraging parents and community members to submit ideas regarding the improvement of the school program. The principal could improve his/her effectiveness by cooperating with civic and service groups in seeking solutions to problems of mutua? concern.

7. One category of teachers (those with 5-8 vears of teaching in the present school) switched the rank order of the areas of school management and staff-principal relations. They placed the area of staff-principal relations second to that of spiritual climate and that of school management third.

8. The most experienced teachers (with ten or more years of teaching), however, perceived the principal's effectiveness differently. An analysis of their responses showed that the principal was most effective in the area of school management, more effective in the area of school-community relations, and effective in the area of spiritual climate. The areas of staff-principal relations and curriculum and instruction were placed last in that order.

\section{Recommendations to the Lake Union Conference}

The following recommendations may be made to the Lake Union 
Conference on the basis of the preceeding research:

1. Academy principals should attempt to discover how the classroom teachers perceive the principals'effectiveness and try to enter into some kind of dialogue between themselves and the teachers for mutual development in their relations.

2. Principals need to improve as leaders in the area of curriculum and instruction.

3. When hiring principals to serve in the academies, consideration should be given to the teaching experience of the candidates in view of their role as instructional leaders in the schools.

4. When hiring academy principals, preference should be given to candidates who demonstrate ability to listen to others and are skillful in human relations as well as in administrative and supervising competencies.

5. Academy principals need to be more out-going in their interaction with parents and other members of the community.

6. Teachers' perceptions of principals' effectiveness can be used as part of a needs assessment in order to plan a practical and effective in-service training for those academy principals already on the job.

\section{Recommendations for Further Research}

1. In order to have a large sample, it is recommended that a study of a similar nature be undertaken in other SDA academies or elementary schools in the continental United States. A large sample will enable a researcher to select respondents through the process of randomization. 
2. It would seem advisable to design a study in which perceptions of superintendents of schools concerning the academy principal's effectiveness would be compared with classroom teachers' perceptions of the effectiveness of the same SDA academy principals.

3. A further suggested possibility would be to undertake a study whose purpose would be to compare principals' perceptions of their own effectiveness in SDA academies with classroom teachers' perceptions of the effectiveness of the principals in those SDA academies. 
APPENDIX A

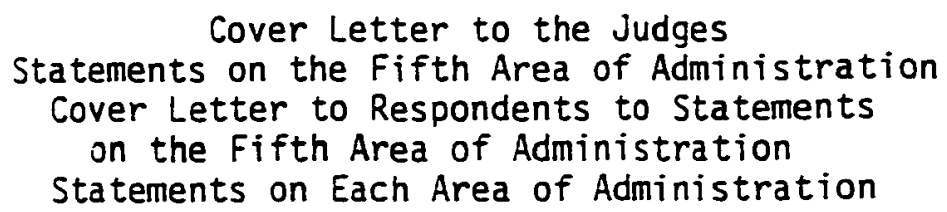

Reproduced with permission of the copyright owner. Further reproduction prohibited without permission. 
?exc eacn item carefully. Iraw a circle around one of the three nucbers following the iter, to snow the answer jou jave selected, according to yoli: judgement.

$$
\begin{aligned}
& 3 \text { - appropriate } \\
& 2 \text { - uncertain } \\
& 1 \text { - inaporopriate }
\end{aligned}
$$

The principal

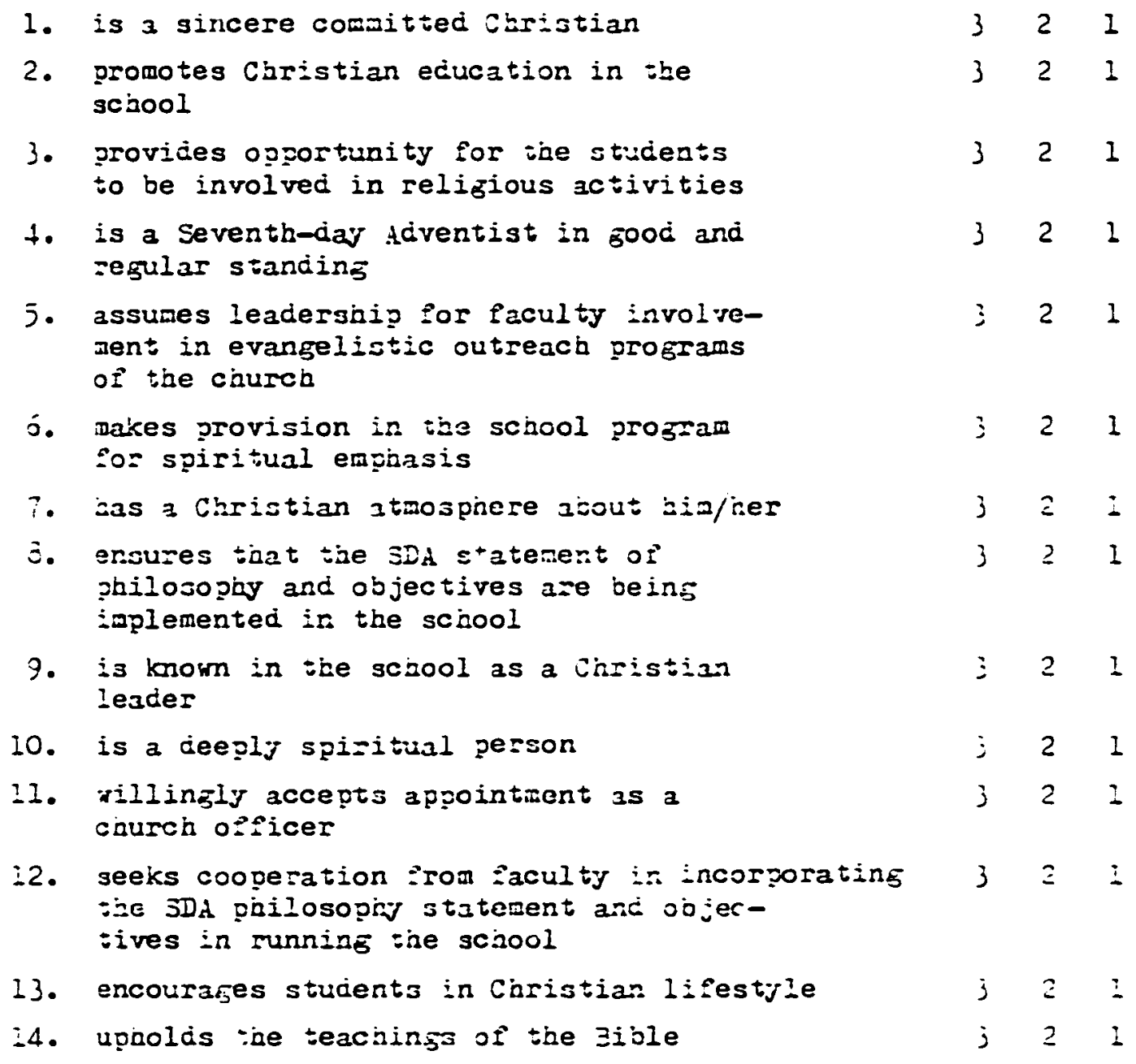




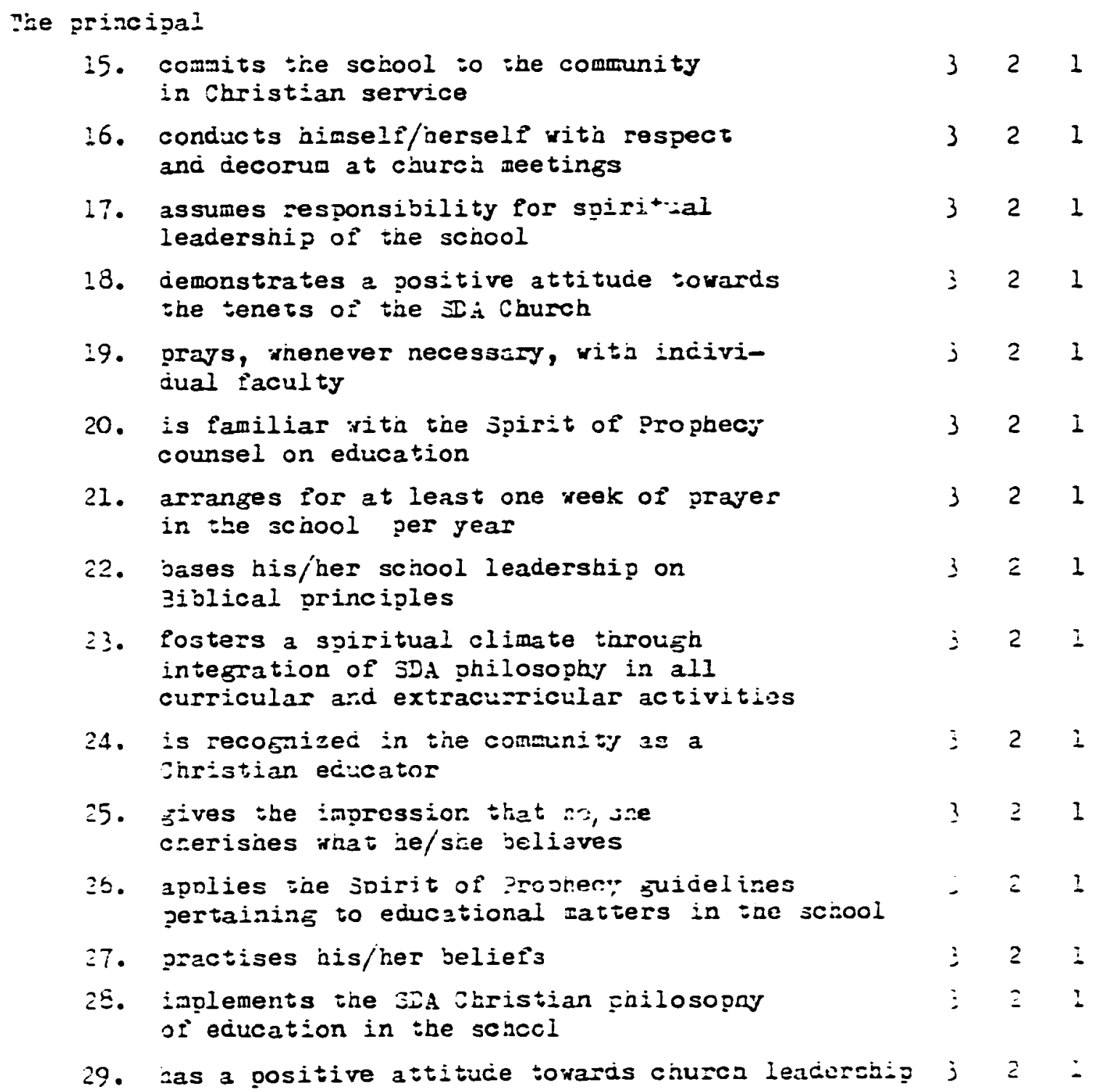

Please write jour coments and/or suggestions on ine rext paje. Thank jou. 


$$
\begin{aligned}
& \text { G-6 Carland Apts } \\
& \text { Gerrien Springs } \\
& \text { Yichigan, } 49103 \\
& \text { Cctober 1, } 1982
\end{aligned}
$$

Dear MrMrshiss

I am developing an instrument for evaluating teachers' perceptions of a Seventhday Adrentist high schcol (acadery) principal's effectireness. Cn pages 2 and 3 there is a list of statements to which teachers could respcnd in expressing their cerceptions of the principal's effectiveness with regard to the spiritual dimension of his/her leaderstip in a Seventh-day Adventist high school (acadeny).

You have taught in a Seventh-dar Adventist high school (academs) before. Will you please express ycur percepticn of your last high school (acadeng) principal's effectiveness with respect to the spiritual dimension of the school by responding tc the statements listed on pages 2 and 3. Pead each item carefully, then draw a circle arcund one of the five mubers following it to show the degree of jour agreement. The numbers stand for the following ratings:

$$
\begin{aligned}
& 5 \text { - strongly agree } \\
& 4 \text { - agree } \\
& 3 \text { - ancertain } \\
& 2 \text { - disagree } \\
& \text { I - strongly disagree }
\end{aligned}
$$

I am most. grateful to jou for your assistance.

Iours sincerely,

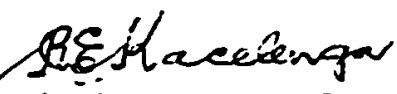

Ritch Enos Kacelenga 


\section{Area: Faculty-principal Relations}

Code

Number
Statement

The principal

1. is sincere in his/her relations with the faculty

6. relates well to the faculty

11. helps the faculty members accomplish their social needs

16. treats the faculty members as professionals

21. respects others' points of view

26. has a good sense of humor

31. is courteous, respectful, patient, and considerate with the faculty

36. makes the facuity members feel worthy in their job

41. supporis the faculty members in conflicts with other supervisors or administrators

46. encourages the faculty to feel free to discuss their personal or professional problems with him/her

51. shows a favorable and cooperative attitude toward the staff

56. helps each member of the faculty deyelop his/her owit individuality

\section{Area: Curriculum and Instruction}

Code

Number

Sta tement

The principal

helps teachers feel secure in what they are doing 
Code

Number

\section{Sta tement}

The principal

7. arranges for in-service training taking into account the professional needs of his/her faculty

12. helps teachers feel free to develop their own unique style of teaching

17. maintains the continuing goal of improving the educational program without frightening others

22. provides guidance and counseling to teachers when needed

27. knows and understands the instructional problems of teachers

32. works with teachers as a team

37. stimulates and encourages teachers' initiative and creativeness

42. encourages teachers to participate in the evaluation of the instructional accomplishments

47. takes an individual interest in each teacher, according to his/her professional needs

52. helps teachers crganize instructional tasks so that time is used at a maximum

57. views himself/herself primarily as a facilitator of the educational process

\section{Area: School Management}

Code Number

Statement

The principal

3. creates a friendly and relaxed working atmosphere

3. makes decisions which reflect administrative knowledge and use of common sense

13. acts quickly and decisively to make sure that proper student discipline is maintained so that the teaching-learning process is allowed to function 
Code

Number

Sta tement

The principal

18. is a re! iable administrator

23. maintains consistent behavior

28. organizes the school in a way that utilizes the staff's skills at a maximum

33. is an objective, impartial, and fair administrator

38. is able to interpret and respond effectively to new conditions, situations, problems, and opportunities, as they arrive

43. understands his/her authority and responsibility

48. encourages staff members to make suggestions regarding school rules and regulations

53. shares planning and decision-making with the staff

58. provides an effective organization

\section{Area: School-community Relations}

Code

Number

\section{Statement}

The principal

4. seeks cooperation from parents and community members in solving school problems of mutual concern

9. assesses community reactions about the educatinnal programs and the school organization

14. promotes mutual trust between $\mathrm{him} / \mathrm{her}$ and members of the community

19. creates and maintains a friendly interaction between the school and members of the community

24. uses parents and community members in improving school environment 
Code

Number

Statement

The principal

29. encourages expressions from the community over schoolrelated matters

34. participates and cooperates with civic and service groups in seeking solutions to problems of mutual concern

39. gives recognition to parents' involvement in school activities

44. knows and understands the problems of the community

49. encourages parents to submit ideas to improve the school program and organization

54. is courteous, patient, and considerate with parents and community members

59. encourages parents to feel free to discuss those problems pertaining to the school

\section{Area: Spiritual Climate}

Code

Number

Sta tement

The principal

5. promotes Christian education in the school

10. provides opportunities for the students to be involved in religious activities

15. makes provision in the school program for spiritual emphasis

20. seeks cooperation from faculty in incorporating the SDA philosophy statement and objectives in running the school

25. encourages students in Christian lifestyle

30. conducts himself/herself with respect and decorum at church meetings

35. demonstrates a positive attitude towards the tenets of the SDA Church

40. bases his/her school leadership on Biblical principles 
Code

Number

\section{Statement}

The principal

45. fosters a spiritual =limate through integration of SDA philosophy in all curricular and extracurricuiar activities

50. practices his/her beliefs

55. has a positive attitude toward church leadership

60. implements the SDA Christian philosophy of education in the school

These 60 statements covering the five functional administrative areas were randomly distributed (every fifth item) throughout. the questionnaire. 
APPENDIX B

Research Approval Form

Acosta-Ramos's Item Score to Total

Score Correlation Analysis

Two-part Questionnaire. 


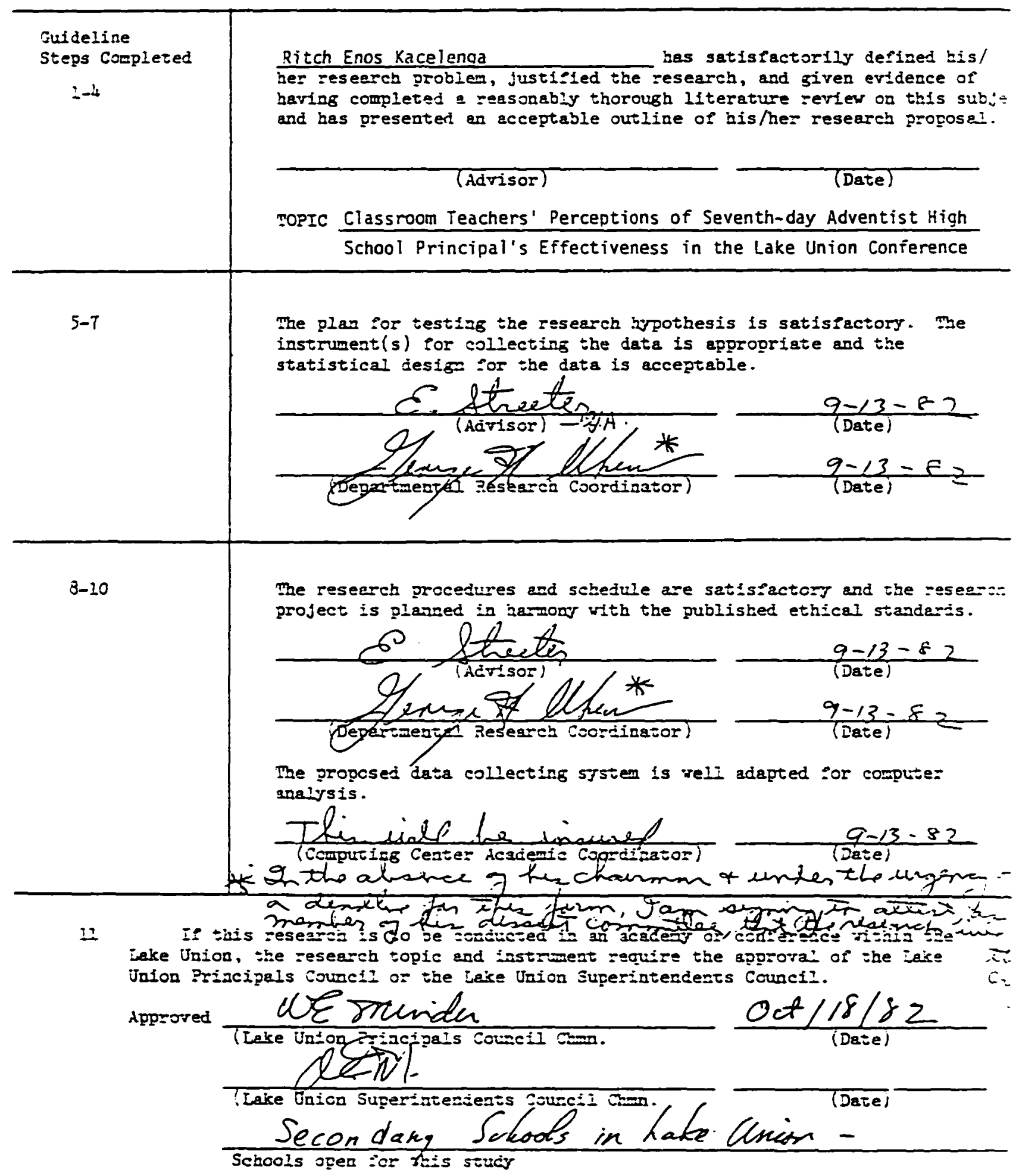


HIGI SCHOOL (ACAOETY) ITACIIER

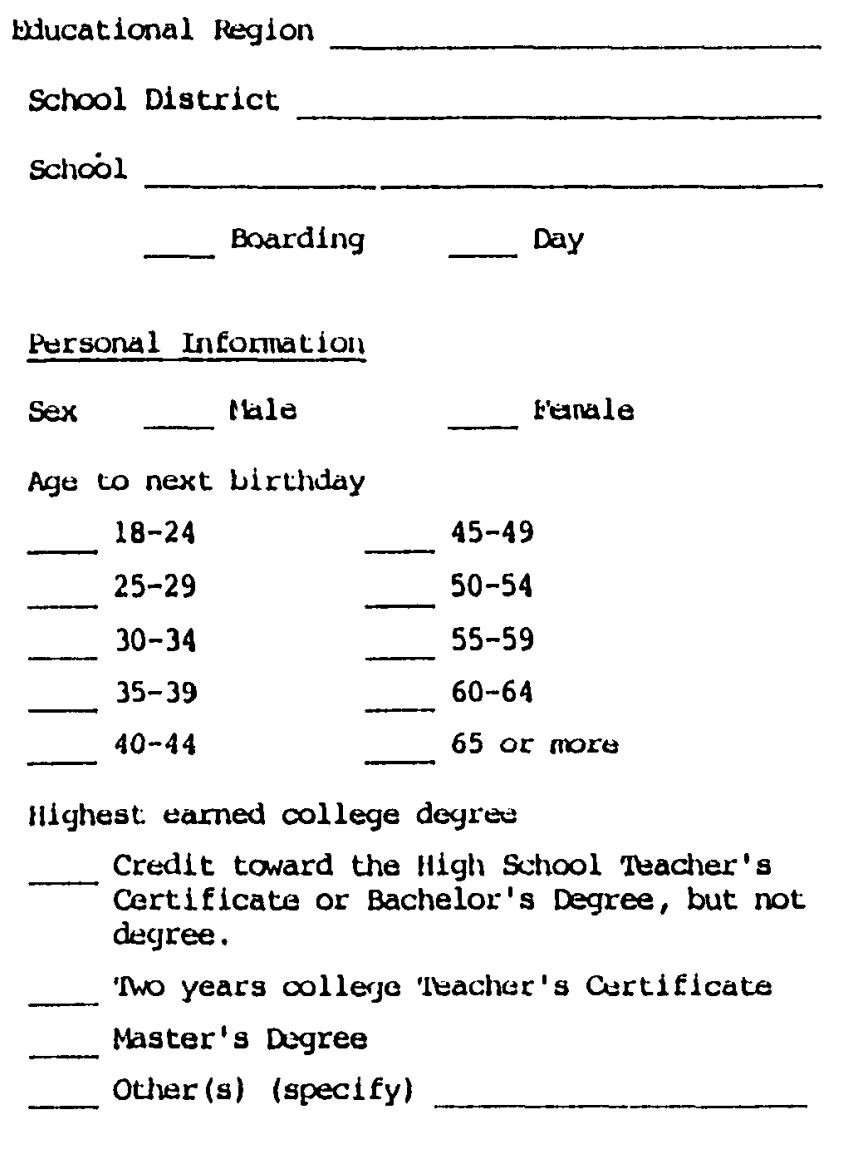

Year last degree was grantexd

$\begin{array}{ll}\text { Prior to } 1950 & -1965-1969 \\ 1950-1954 & -1970-1974 \\ 1955-1959 & -1975-1979 \\ 1960-1964 & - \text { After } 1979\end{array}$

Years of teaching experience, excluding 1982

\begin{tabular}{|c|c|}
\hline $0-4$ & $20-24$ \\
\hline $5-9$ & $25-2 ! ?$ \\
\hline $10-14$ & $30-34$ \\
\hline $15-19$ & More than 34 \\
\hline
\end{tabular}

Years teaching in this school, excluding 1982

\begin{tabular}{ll} 
Less than 1 & \multicolumn{1}{c}{$13-16$} \\
$1-4$ & $17-20$ \\
$5-8$ & \\
$9-12$ & \\
$21-24$ \\
\hline
\end{tabular}




\section{INSIKUCFICNS}

The iteris in this questionnalre describe typical skills and personal characteristics of a high school (acadeny) principal. please indicate the degree of agreenent, according to your jidcgnent, with which these itens characterize your principal. iten:

Printed below is an exartisle of a typical

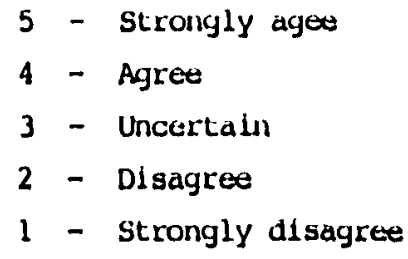

\section{Examole}

The principal is a nice person 5(4) 321

In this exarmle, the respondent circled 4 to indicate that according to his/her judgment he/she agrees with the presence of this behavior in the school principal. The respondent is free to choose any of the five alternatives.

Please circle your response clearly, as show in the example.

Ithank you.
Read each iten carefully. Draw a circle around one of the five numbers, following the itan, to show the answer you have selected, according to your judgment.

Ithe principal

Strongly Strongly

1. is sincere in his/her relations with the faculty

2. helps teachers feel secure in what they are doing

3. creates a friendly and relaxed working atmosphere

4. seeks cooperation from parents $\begin{array}{llllll}4 & 4 & 3 & 2 & 1\end{array}$ and conmunity memlors in solving school problens of mutual concern

5. pronotes Ciristian education in $\begin{array}{llllll}5 & 4 & 3 & 2 & 1\end{array}$ the school

6. relates well to the faculty $54 \begin{array}{llll}5 & 2 & 1\end{array}$

7. arranges for in-service training $\begin{array}{llllll}5 & 4 & 3 & 2 & l\end{array}$ taking into account the professional needs of his/her faculty

8. makes decisions which reflect $\begin{array}{llllll}5 & 4 & 3 & 2 & 1\end{array}$ administrative knowledge and use of calmon sense

9. assesses community reactions about the educational programs and the school organization

10. provides oportunities for the stuident's to be involved in reliyious activities 
Tlie principal.

11. helps the faculty menbers accarplish their social needs

12. holps teachers feel free to develup their own unique style of teaching

13. acts quickly and decisively to make sure that proper student discipline is maintained so that the teachinglearning process is allowed to function

14. prumblus lmatual trust between him/her and mentuers of the cammity

15. makes provision in the school projram for spiritual enphasis

16. treals the faculty nenbers as profossionals

17. maintains the continuing goal of improving the educational proxran without frightening others

18. is a reliable adininistrator

19 creates and naintains a friendly interaction between the school and munters of the connunity

20. seeks cooperation fran faculty in incorporating the SDA philosophy statement and objectives in running the school

21. respects others' points of vicas $\begin{array}{rrrrr}5 & 4 & 3 & 2 & 1\end{array}$

$\begin{array}{lllll}5 & 4 & 3 & 2 & 1\end{array}$

$\begin{array}{lllll}5 & 4 & 3 & 2 & 1\end{array}$

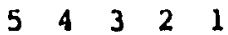

$\begin{array}{lllll}5 & 4 & 3 & 2 & 1\end{array}$

$\begin{array}{lllll}5 & 4 & 3 & 2 & 1\end{array}$

$\begin{array}{lllll}5 & 4 & 3 & 2 & 1\end{array}$

$\begin{array}{lllll}5 & 4 & 3 & 2 & 1\end{array}$

$\begin{array}{lllll}5 & 4 & 3 & 2 & 1\end{array}$

$\begin{array}{lllll}5 & 4 & 3 & 2 & 1\end{array}$

The principal

22. provides guldance and counseling SA to tcachers when needed

23. inaintains consistent belsavior $\quad \begin{array}{llllll}5 & 4 & 3 & 2 & 1\end{array}$

24. uses parents and comunity members $\begin{array}{llllll}5 & 4 & 3 & 2 & 1\end{array}$ in inproving sclrool envi ronment

25. encourages students in Cristian $\begin{array}{lllll}5 & 4 & 3 & 1\end{array}$ lifestyle

26. has a good sense of humbr $\quad \begin{array}{llllll}5 & 4 & 3 & 2 & 1\end{array}$

27. knows and understands the instruc- $\begin{array}{ccccc}5 & 4 & 3 & 2 & 1\end{array}$ tional problems of teachers

28. organizes the school in a way that $\begin{array}{lllll}5 & 4 & 2 & 1\end{array}$ utilizes the staff's skills at a maxinum

29. encouracjes expressions from the connunity uver school-related natters

30. conducts himself/herself with re- $\begin{array}{ccccc}5 & 4 & 3 & 2 & 1\end{array}$ spect and decorum at church meetings

31. is courteous, respectful, patient $\begin{array}{llllll}5 & 4 & 3 & 2 & 1\end{array}$ and considerate with the faculty

32. horks with teachers as a tean $\quad \begin{array}{lllllll}5 & 4 & 3 & 2 & 1\end{array}$

33. is an objective, impartial, and $543 \quad 21$ fair administrator

34. participates and cooperates with $\begin{array}{llllll}5 & 4 & 3 & 2 & 1\end{array}$ civic and service groups in seeking

solutions to problens of nutual concern 
'the principal

35. dermustrates a positlve attitude towards the tenets of the SDh Church

36. Nukis the faculty munbers feel worthy in their job

37. stimulates and enoourages teachers' initiative and creativeness

38. is able to interpret and respond ffectively to new conditions, situm ations, problens, and opportunities. as they arrive

39. gives recognition to parents' involve- $\begin{array}{llllll}5 & 4 & 3 & 2 & 1\end{array}$ mant in sctool activities

40. Lases his/her school leadership on $\quad \begin{array}{lllll}4 & 3 & 2\end{array}$ Biblical principles

41. supports the taculty members in conlilcts with other supervisors or adninistrators

42. encouracjes teachors to participate in the evaluation of the instructional acocnel ishmont:s

43. understands his/her authority and responsibility

44. knows and understands the problens of $\begin{array}{lllll}5 & 4 & 3 & 2\end{array}$ the comnunity

45. fosters a spiritual climate through integration of SDA philosophy in all curricular and extracurricular activities

$\begin{array}{lllll}5 & 4 & 3 & 2 & 1\end{array}$
The principal

46. encourages the faculty to feel

SA free to discuss their personal or professional problons with him/her

47. takes an individual interest in each leacher, according to his/her urofessional netds

48. encourages staff menbers to nake suggestions regarding school nules and requlations

49. encourages parents to subnit idcas $\begin{array}{llllll}5 & 4 & 3 & 2 & 1\end{array}$ to inmrove the school progran and organization

50. practices his/her beliefs

$\begin{array}{lllll}5 & 4 & 3 & 2 & 1\end{array}$

51. slows a favorable and cooperative $\begin{array}{llllll}5 & 4 & 3 & 2 & 1\end{array}$ attitude toward the staff

52. helps teachers organize instructional tasks so that time is used

$\begin{array}{lllll}5 & 4 & 3 & 2 & 1\end{array}$ at a maxinium

53. shares planning and decision-liaking $\begin{array}{llllll}5 & 4 & 3 & 2 & 1\end{array}$ with the staff

54. is courteous, patient, and con- $\quad \begin{array}{lllllll}5 & 4 & 3 & 2 & 1\end{array}$ siderate with parents and community menbers

55. has a positive attitude toward church leadership

56. helps each menber of the faculty $\begin{array}{lllll}5 & 4 & 3 & 2 & 1\end{array}$ develop his/her own individuality 


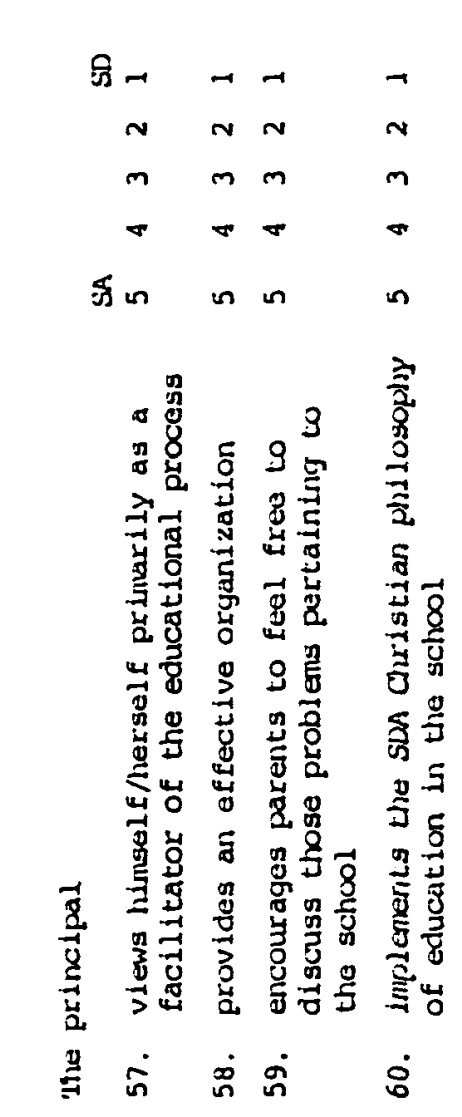




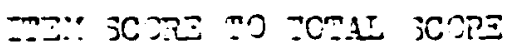

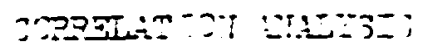

\begin{tabular}{|c|c|c|c|}
\hline $\begin{array}{l}\text { Een } \\
\text { inizer }\end{array}$ & Yean & $\begin{array}{c}\text { Standard } \\
\text { Jev. }\end{array}$ & $\begin{array}{l}\text { Torrelation } \\
\text { joefficient }\end{array}$ \\
\hline$I$ & 1.00 & $.9 ?$ & .78 \\
\hline 2 & 3.92 & .99 & .36 \\
\hline 3 & 1.22 & .92 & .34 \\
\hline 1 & \pm .05 & .93 & .75 \\
\hline 5 & 4.08 & .97 & .3L \\
\hline 5 & 3.79 & I. $\mathfrak{I}$ & .72 \\
\hline$?$ & 1. 22 & 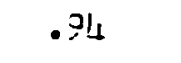 & .79 \\
\hline 3 & 3.32 & I. 32 & $-: 2$ \\
\hline$?$ & 3.39 & 1.20 & .78 \\
\hline 10 & 4.17 & .99 & .72 \\
\hline$I I$ & $j .97$ & \pm .30 & .78 \\
\hline$\square 2$ & 3.32 &.$\ni 3$ & .?9 \\
\hline 13 & 1.19 & .90 & .32 \\
\hline I4 & 1.02 & 1. 24 & .39 \\
\hline 15 & 2.08 & .38 & .77 \\
\hline 16 & 3.07 & .38 & .32 \\
\hline 17 & \pm .12 & .39 & .32 \\
\hline 18 & 4.01 & 1.05 & $.3 I$ \\
\hline I? & 노그 & .37 & .73 \\
\hline 20 & 3.91 & .38 & .79 \\
\hline $2 I$ & 6.12 & . & .75 \\
\hline
\end{tabular}




\begin{tabular}{|c|c|c|c|}
\hline $\begin{array}{l}\text { Zor: } \\
\text { Sumber }\end{array}$ & "san & $\begin{array}{c}\text { Standard } \\
\text { Jer. }\end{array}$ & $\begin{array}{l}\text { Correlation } \\
\text { Coefficient }\end{array}$ \\
\hline 22 & 1.0 & .97 & .86 \\
\hline 23 & 3.97 & .96 & .34 \\
\hline 24 & 3.79 & .94 & .30 \\
\hline 25 & 4.12 & .97 & . 37 \\
\hline 26 & 4.02 & $1 . \Omega$ & .78 \\
\hline 27 & 3.91 & 1.12 & .37 \\
\hline 28 & 3.92 & .95 & .79 \\
\hline 29 & 3.97 & 1.00 & .32 \\
\hline 30 & 4.02 & .99 & .36 \\
\hline $3 I$ & 4.18 & .38 & .68 \\
\hline 32 & 1.21 & .92 & .76 \\
\hline 33 & 3.32 & 1.04 & .30 \\
\hline 34 & 1.13 & .92 & .32 \\
\hline 35 & 4.29 & .87 & .79 \\
\hline 36 & 3.999 & .94 & . is \\
\hline 37 & 3.93 & I. 27 & .35 \\
\hline 38 & 3.91 & 1.38 & .39 \\
\hline 39 & 3.90 & .98 & .77 \\
\hline Dים: & 3.88 & .97 & .32 \\
\hline in & 1.05 & .97 & .32 \\
\hline 12 & 3.99 & .95 & .36 \\
\hline$\div 3$ & 3.94 & .96 & .31 \\
\hline كندا & 4.15 & .91 & .32 \\
\hline 45 & 3.99 & .97 & .30 \\
\hline
\end{tabular}




\begin{tabular}{cccc}
$\begin{array}{c}\text { iter: } \\
\text { sijer }\end{array}$ & "ean & $\begin{array}{c}\text { Standard } \\
\text { Jev. }\end{array}$ & $\begin{array}{c}\text { Oorrelation } \\
\text { joefficient }\end{array}$ \\
46 & 3.99 & .96 & .33 \\
47 & 4.99 & .92 & .30 \\
48 & 4.07 & .92 & .76 \\
\hline
\end{tabular}

Reliabilitg Coefficient Iipha $=.98992$ 


\section{APPENDIX C}

Letter from the Director of Education Granting Permission to the Researcher to Conduct Research in the Lake Union Conference Academies.

Cover Letter from Researcher to Respondents Explaining the Purpose of the Research. Cover Letter from the Director of Education to Academy Principals.

Cover Letter from the Director of Education to Academy Teachers.

Letter from Researcher Reminding Respondents to

Return Questionnaire. 


\section{EOENFERENEE

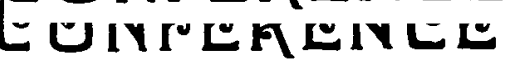

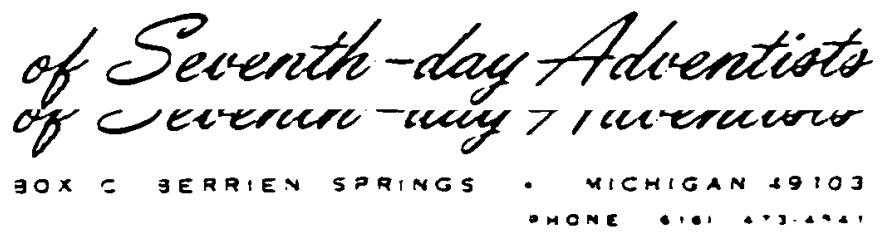

October 19, 1982

Mr. Ritch E. Kacelenga

Garland Apartments, G-6

Berrien Springs, MI 49103

Dear Mr. Kacelenga:

I am happy to inform you that the questionnaire which you presented for review by the members of the Educational Management Team met with the approval of the educators, and you are now free to move ahead with your work.

We wish you the Lord's blessing in this project.

Sincerely yours,

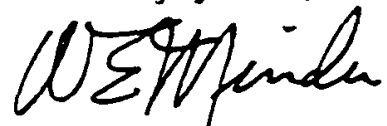

N. E. Minder

Director

OFFICE OF ENUCATION

da

Encl. Signed approval form 
Garland Apt. G-6

Berrien Sorings, sII 49103

November 1, 1982

Dear Mr/lis

I write this letter to request your assistance in connection with a study I an conducting in SDA academies in the Iake Union conEerence. After teaching overseas in two of our SDA high schools for several years, I came to Andrews oniversity to study educational leadership in the Graciuate school.

Ny dissertation will study the SDA high school, especially with regard to its leadership. I need not remind you that at the heart of every acininistration is leadership. Research shows that an organization without effective leadership is in trouble, that leaders can make or break a group, and that "the difference between a good school and a soor school is often the difference between a good and poor principal. it good school invariably means strong leacership by the principal" (Conant, 1960).

The purpose of iny study is to identify classrocm teachers' serceptions of the SDA high school (acadeny) principal's effectiveness in carrying out his/her functional acministrative responsibilities in and around the school.

Enclosed with this letter is a questionnaire designed to collect data for the study. The first part of the instrument asks for demograthic and professional data without identifying the resoondent by name. the second part consists of statements that describe typical skills and personal characteristics of a high school (academy) principal. I should be most grateful if you would please take a fen ninutes of your busy ine to complete the questionnaire the jay you receive it and return it zight away in the enclosed stamped and self-addressed envelooe. I assure you that your responses will receive the most confidential treatment and what at the conclusion of the stuoy, the questionnaire will be destroyed.

once again, may I thank you for your cooperation and for promotIy returning the questionnaire.

Yours sincerely,

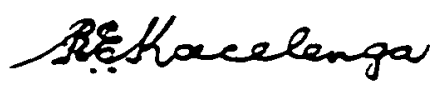

R. E. Racelenga 
November 10,1982

\section{Loke Union \\ Conference of \\ Seventh-doy \\ Adventists}

ACADEMY PRINCIPALS

Lake Union Conference

Dear Principals:

Enclosed you will find a sufficient number of Ritch Kacelanga's research questionnaires to supply one to each of your teachers. You will remember that $\mathrm{Mr}$. Kacelenga's research instrument was presented to the principals at our Au Sable Administrators Seminar and approval was granted at that time for him to proceed with this research.

As you will notice, I have included a letter along with the questionnaires so the teachers will know that the project has been approved.

We are requesting you to please be responsible for handing these questionnaires to your faculty at your first opportunity. In order to maintain confidentiality, teachers will return them direct to $\mathrm{Mr}$. Kacelenga in the stamped envelopes provided. Please impress your teachers with the importance of participation in order to make the research valid.

Your cooperation will be appreciated.

Sincerely yours,

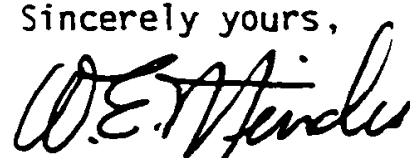

'A. E. Minfer

Director

OFFICE OF EDUCATION

da

Encis. 
November 10,1982

\title{
Lake Union Conference of \\ Seventh-doy Rdventists
}

\author{
ACADEMY TEACHERS \\ Lake Union Conference \\ Dear Teachers:
}

Re: Ritch Kacelenga's Research Study

Mr. Ritch Kacelenga, a doctoral student at Andrews University, has received permission from the Lake Union Conference Educational Management Team to conduct his research in Lake Union academies. His questionnaire (enclosed) has been approved by this group and is now being passed on to you.

Please take a few minutes to fill in this questionnaire. As you will note, the information requested is of a confidential nature-for this reason a stamped, addressed envelope is enclosed for its return direct to $\mathrm{Mr}$. Kacelenga. Mr. Kacelenga has been an administrator in Adventist schools for many years, and you may be assured that all information will be handled in strict confidence.

We are interested in this study and feel it will provide a useful tool for improved administration in our secondary schools. Please participate so the research will be worthwile and valid.

Sincerely yours,

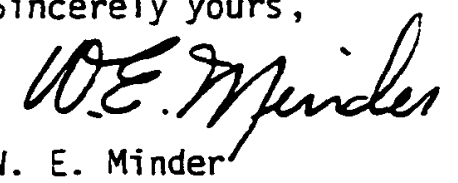

v. E. Minder

Director

OFFICE OF EDUCATION

aa

Encls. 
G-6 Garland Apartments

Berrien Springs, MI, 49103

December 1, 1982

Dear Mr/Ms

Three weeks ago, I wrote you a letter kindly requesting you to respond to a questionnaire which was enclosed together with the letter. As I have not heard from you since then, I can only assume that your busy schedule has not allowed you to complete the questionnaire.

This letter is a further request to you to please fill in the questionnaire and send it off by return mail so that it reaches me by Wednesday, December 8 , the day on which the Fall Quarter will close here at Andrews University. Your contribution is very important for the success of this study. In case the first cooy of the questionnaire was lost, enclused please Eind another copy herewith.

Once again I am most grateful to you for your assistance and cooperation.

Very Sincerely Yours,

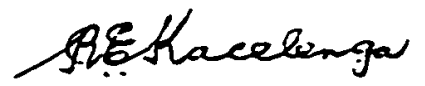

R. E. Kacelenga 
Abre 11, R. L., and Itanna, Ch. "Symbolic Interactionism and Sudervisorteacher Relationships." Clearing House 51 (May 1978):439-443.

Acosta-Ramos, José A. "Teachers' Perceptions of Principal's Effectiveness in Puerto Rico." Ed.D. degree dissertation, Lehigh University, Bethlehem, Pennsylvania, 1973.

Anderson, Lester W., and Van Dyke, Lauren A. Secondary School Administration. Boston: Houghton Miff

Bagby, Geraldine. "Help Wanted: Instructional Leadership." NASSP Bulletin 56 (November 1972):40-46.

Ban, John R. "25 Cardinal Principles for the School Principal." Clearing House 44 (March 1970): $441-445$.

Brieve, Fred J. "Secondary Principals as Instructional Leaders." NASSP Bulletin 56 (December 1972):11-15.

Brown, Allan F. "Reactions to Leadership." Educational Administrative Quarterly 3 (Winter 1967):62-73.

Buffington, R. L., and lledsker, L. L. "Teachers and Parents Describe the Effective Principal's Behavior." Administrator's Notebook 4 (September 1955):1-4.

Bush, Robert N. "What Should Be the Relationship of Teachers and Administrators in Instructional Improvement?" NASSP Bulletin 39 (April 1955):246-248.

Campbell, Melton V. "Teacher-Principal Agreement on the Teacher Role." Administrator's Notebook 7 (February 1959):1-4.

Campbell, Roald F. The Organization and Control of American Schools. Columbus, Ohio: Charles E. Merril Books. Inc.. 1965:

Carruthers, Snowden. "A Study of the Instructional Role of Southern Secondary School Principals as Perceived by Selected Secondary School Principals and Teachers." Ed.D. degree dissertation, University of Tennessee, 1977.

Christiansen, W. S. "The Influence of the Behaviors of the Elementary School Principal upon the School He Administers." Dissertation Abstracts 22 (April 1962):3483. 
Cobb, J. J. "The Role of Principals as Viewed by Principals, Teachers, and Prospective Teachers." American Secondary Education 8 (January 1978): 40-45.

Connant, J. B. Education in the Junior High School Years - a Memorandum to School Boards. Princeton, liew Jersey: Educational Testing Service, 1960.

Douglass, H. R. Supervision in Secondary Schools. Cambridge: The Riverside Press, 1961.

Education Directory 1982-83. Lake Union Conference, Berrien Springs, Michigan.

Eppley, George Edward. "A Study of the Interrelationships of Teachers" Perceptions of Principals' Self-ratings of Effectiveness and Teachers' Self-ratings of Confidence in the Principals' Leadership, Effectiveness, and Satisfaction in the High Schools of the Catholic Diocese of Cleveland." Ph.D. degree dissertation, Case Western Reserve University, 1967.

Evaluative Criteria for SDA Secondary Schools. North American Division Commission on Accreditation of the Board of Regents, General Conference Department of Education, 1982.

Felton, J. N., and Asbury, Ch. A. "Role and Effectiveness: How Junior High Students Perceive Their Principal." NASSP Bulletin 62 (1978): 104-111.

Fiedler, F. E. Leadership and Effective Management. Glenview, Illinois: Scott Foresman, 1974.

Fox, R. S. (Chairman). School Climate Improvement: A Challenge to the School Administrator. Phi Delta Occasional Paper, 1974.

Gauerke, 'Narren E. Legal and Ethical Responsibilities of School Personnel. Englewood Cliffs, New Jersey: Prentice-Hall Inc., 1959.

Gentry, H. W., and Kenney, J. B. "The Performance of El ementary School Principals as Evaluated by Principals and Teachers." In 0. T. Jarvis (ed.), Elementary School Administration: Readings. Dubuque, Iowa, Wm. C. Brown Co., 1969.

Goldman, Samuel. The School Principal. New York; The Center for Applied Research in Education, Inc., 1966.

Gordon, Thomas. Leader Effectiveness Trainina; L.E.T.: The No-Lose fay to Release the Productive Potential of People. [New York]: Wyden Books, c. 1977. 
Gore, Nilliam J., and Silander, F. S. "A Bibliographical Essay on Decision-Making." Administrative Science Quarterly 4 (June 1959): 97 .

Greer, F. Loyal; Galanter, Eugene H.; and Nordlie, Peter G. "Interpersonal Knowledge and Individual and Group Effectiveness." Journal of Abnormal and Social Psychology 49 (July 1954): 411-414.

Grieder, Calvin; Pierce, Truman M.; and Jordan, K. Forbis. Public School Administration. New York: The Ronald Press Company, 1969.

Griffiths, D. E.; Hemphill, J. K.; and Fredericksen, N. Administrative Performance and Personality: A Study of the Principal in a Simulated Elementary School. New York: Bureau of Publications - Teachers College, Columbia University, 1962.

Gross, N., and Herriott, R. E. "The EPL of Elementary Principals: A Study of Executive Professional Leadership." In 0. T. Jarvis (ed.), Elementary School Administration: Readings. Dubuque, Iowa: wim. C. Brown Co., 1969.

Hopper, R. L., and Bills, R. E. "What's a Good Administrator Made of?" School Executive 74 (March 1955):93-95.

Jarvis, 0. T. (ed.) Elementary School Administration: Readings.

- Dubuque, Iowa: W. Brown Co., 1969.

Jones, James J.; Salisbury, C. Jackson; and Spencer, Ralph L. Secondary School Administration. New York: McGraw-Hill Company, 1969.

Kimbrough, Ralph B. Administering Elementary Schools. New York: The MacMillan Company, 1968.

Lee, Bill D. "Critical Incidents of Supervisory Functions of Principals in Southeastern New Mexico. Ed.D. degree disseration, East Texas State University, 1974.

Lippitt, Ronald, and White, Ralph $K$. "An Experimental Study in Leadership and Group Life." In Readings in Social Psychology.

Edited by Theodore M. Newcomb, et al. New York: Henry Holt and Company, 1947.

Lozeau, G. A. "The Role of the Principal Today." In The North Central Association Quarteriy 52 (Fall 1977):335-340.

McIntyre, Kenneth B. "Evaluating the Performance in the Administration and Improvement of the Instructional Program." Austin: University of Texas, 1972. (Mimeographed.) 
Mead, Nehemiah. "The Leadership Behavior of Jamaican High School Principals: Perceptions and Expectations of Teachers and Principals." Ed.O. degree dissertation, Andrews University, Berrien Springs, Micnigan, 1976.

Melton, George. The Principalship: Job Specifications and Salary Considerations for the '70s. Washington: National Association of Secondary School Principals, 1970.

Michel, Marianne. "The Changing Role of the Principal as a Response to Teaching Unionism in Educational Organization." Thrust 5 (May 1976):23-25.

Moyer, Donald G. "Leadership that Teachers Want." Administrator's Notebook 3 (March 1955):1-4.

Myers, Robert B. "The Development and Implications of a Conception of Leadership for Leadership Education." Ed.D. degree dissertation, University of Florida, 1954.

National Association of Secondary School Principals. Job Descriptions for Principals and Assistant Principals: The Current Trends. Reston, Virginia: National Association of Secondary Schooi Principais, 1976.

Neagley, Ross L., and Evans, N. Dean. Handbook for Effective Supervision of Instruction. Englewood Cliffs, New Jersey: Prentice HalT, Inc., 1964.

Neufeld, Don F. Seventh-day Adventist Encyclopedia. Washington, D.C.: Review and Herald Publishing Association, 1976.

Prascher, R. E. "Effective and Ineffective Administrative Behavior Exhibited by High School Principals as Judged by a Selected Group of Colorado Classroom Teachers." Colorado Journal of Educational Research 14 (Summer 1975):41. (Abstract).

Riggs, Norman D. "Organization for Instruction." Clearing House 44 (September 1969): 45-49.

Schutz, W. C. Procedures for Identifying Persons with Potential for Public School Administrative Positions. Berkeley: University of California, 1961. (Cooperative Research Program).

Sharpe, R. T. "Differences between Perceived Administrative Behavior and Role-Noms as Factors in Leadership Evaluation and Group Morale." Dissertation Abstracts 16 (January 1956):57. (University Microfilms, No. 15, 384). 
Shearon, Ronald $w$. Correlates of Administrative Professional Leadership in the North Carolina Agricultural Extension Service. U.S. Educational Resources Information Center, ERIC Document ED 025729.

Silberman, A. "The Principal Principle." Ladies Home Journal (October 1974):50-51.

Spindier, G. D. "The Role of the School Administrator." In G. D. Spindler (ed.). Education and Culture. New York: Holt, Rinehart and Winston, 1963.

Stewert, S. Gordon. "The Principal's Efficiency as an Instructional Leader." Virginia Journal of Education 60 (February 1967): 18-20.

Stoops, Emery; and Johnson, Ruse11. Elementary School Administration New York: McGraw-Hill Company, 1967.

Sweitzer, Robert, et a1. Role Expectations and Perceptions of School Principais. U.S. Educational Resources Information Center, 1965. ERIC Document ED 001210.

Trump, J. Lloyd. "Principal Most Potent Factor in Determining School Excellence." NASSP Bulletin 56 (March 1972):3-6.

University of Tennessee. Characteristics of School Administrators. Knoxville, Tennessee: University of Tennessee, College of Education, 1959. (A Kellogj Project).

Yearbook of Seventh-day Adventists, 1980. Statistical Supplement. Washington, D.C.: Review and Herald Publishing Association, 1980.

Wallace, Betty Cloer. "A Study of Junior High School Teachers" Perceived Satisfaction with Their Principals in Regard to Selected Organizational Processes and Leadership Problem Interaction." Ed,O. degree dissertation. IIniversity of Georgia, 1981.

Wellish, J.; MacQueen, A. H.; Carriere, R. A.; and Duck, G. A. "School Management and Organization in Successful Schools." Sociology of Education 51 (July 1978):211-226.

Wittmer, J., and Loesch, L. "A Study of Teacher-Principal Relationships." The Humanist Educator 15 (December 1976):98-105.

Winer, B. J. Statistical Principles in Experimental Design. New York: McGraw-Hili Company, 1971. 
VITA

Name: $\quad$ Ritch Enos Kacelenga

Date of Birth: 6th December, 1927

Place of Birth: Chiradzulu, Malawi

Education: $\quad 1951$ Matriculation, University of London

1961 Bachelor of Arts - English, Nyanja

University of South Africa, P.0. Box 392 ,

Pretoria, S.A.

1965 Post-graduate Certificate in Education University of London

1980 Master of Arts - English

Andrews University, Berrien Springs, Michigan, 49104.

1983 Doctor of Education - Educational Administration.

Andrews University, Berrien Springs, Michigan, 49104.

Professional

Experience:

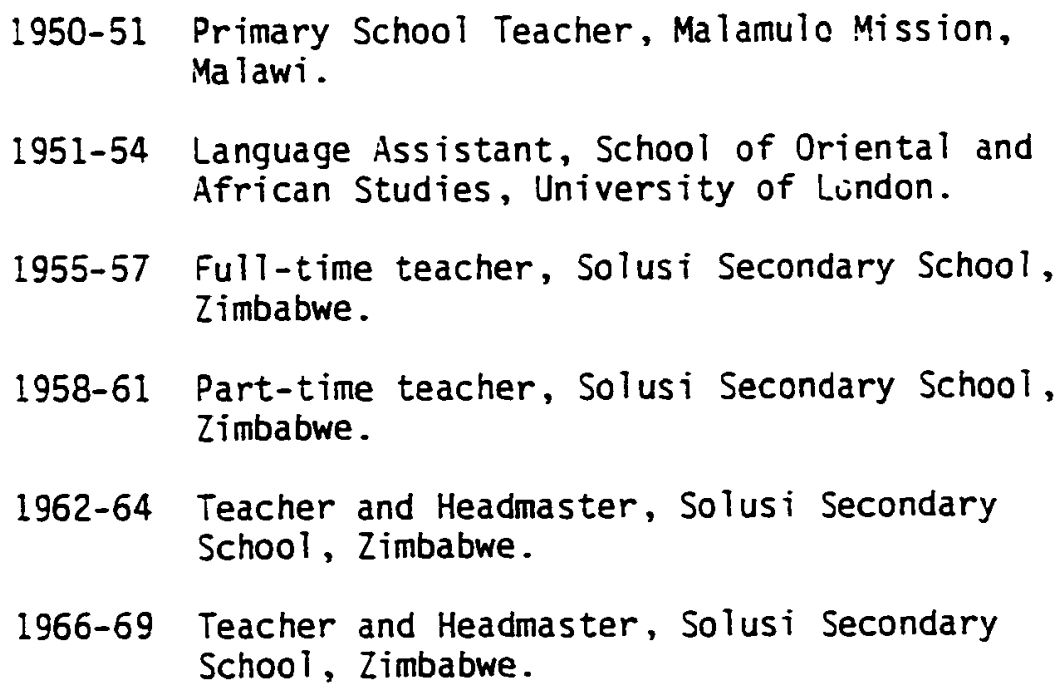


1969-73 Teacher, Principal, Inyazura Secondary School, Zimbabwe.

1974-76 Teacher and Headmaster, Solusi Secondary School, Zimbabwe.

1977 Head of English Department, Solusi Secondary School, Zimbabwe.

1978 Teacher and Headmaster, Solusi Secondary School, Zimbabwe.

1983 - Principal/Headmaster, Lower Gwelo Adventist Secondary School, Zimbabwe. 